\title{
SLOVAK REPUBLIC: 2017 Article IV Consultation-Press Release; Staff Report; and Informational Annex For Slovak Republic
}




\title{
INTERNATIONAL MONETARY FUND
}

March 2017

\section{SLOVAK REPUBLIC}

IMF Country Report No. 17/71

\section{ARTICLE IV CONSULTATION_PRESS RELEASE; STAFF REPORT; AND INFORMATIONAL ANNEX FOR SLOVAK REPUBLIC}

Under Article IV of the IMF's Articles of Agreement, the IMF holds bilateral discussions with members, usually every year. In the context of the 2017 Article IV consultation with the Slovak Republic, the following documents have been released and are included in this package:

- A Press Release on the staff report that concluded the Article IV consultation with the Slovak Republic.

- The Staff Report prepared by a staff team of the IMF for the Executive Board's consideration on a lapse of time basis, following discussions that ended on February 2, 2017, with the officials of the Slovak Republic on economic developments and policies. Based on information available at the time of these discussions, the staff report was completed on February 23, 2017.

- An Informational Annex prepared by the IMF staff.

The documents listed below have been or will be separately released.

Selected Issues

The IMF's transparency policy allows for the deletion of market-sensitive information and premature disclosure of the authorities' policy intentions in published staff reports and other documents.

\author{
Copies of this report are available to the public from \\ International Monetary Fund • Publication Services \\ PO Box 92780 • Washington, D.C. 20090 \\ Telephone: (202) 623-7430 • Fax: (202) 623-7201 \\ E-mail: publications@imf.org Web: http://www.imf.org \\ Price: $\$ 18.00$ per printed copy
}

\section{International Monetary Fund Washington, D.C.}




\section{IMF Executive Board Concludes Article IV Consultation with Slovak Republic}

On March 17, 2017, the Executive Board of the International Monetary Fund (IMF) concluded the Article IV consultation ${ }^{1}$ with Slovak Republic, and considered and endorsed the staff appraisal without a meeting. ${ }^{2}$

Slovakia is an economic success story. Sustained convergence since 1995 has lifted real per capita GDP to over 70 percent of the European Union average and the post-crisis recovery has been one of the most robust in Europe. After picking up in 2015, thanks to the exceptionally high absorption of EU funds at the end of the 2007-2013 programming period, real GDP growth is projected to moderate in 2016 but remain robust at 3.3 percent. Growth continues to benefit from an improving labor market, low inflation and strong household credit growth. The output gap is now closed. Fiscal consolidation resumed in 2016, and the fiscal deficit is estimated to have narrowed to 2 percent of GDP. Although public debt remains low and sustainable, it is not far below domestic debt brake thresholds. The banking sector remains stable and profitable, whereas private sector credit growth remains among the highest in the EU.

The outlook is favorable with growth expected to peak at 3.9 percent in 2019, and settle around 3.5 percent thereafter, reflecting the expansion of export capacity from investments in the automotive industry. The current account surplus is also expected to rise, with developments in Europe and key export markets constituting the main external risks.

However, significant challenges lie ahead. Slovakia faces some of the most acute regional disparities and worst aging pressures in Europe. Although all regions have seen declining unemployment and some increase in per capita income over the last decade, gains have not been evenly shared but rather heavily concentrated in the Bratislava region - where unemployment is lower and per capita income is much higher. Much of these disparities can

\footnotetext{
${ }^{1}$ Under Article IV of the IMF's Articles of Agreement, the IMF holds bilateral discussions with members, usually every year. A staff team visits the country, collects economic and financial information, and discusses with officials the country's economic developments and policies. On return to headquarters, the staff prepares a report, which forms the basis for discussion by the Executive Board.

${ }^{2}$ The Executive Board takes decisions under its lapse-of-time procedure when the Board agrees that a proposal can be considered without convening formal discussions.
} 
be explained by lower levels of education and underdeveloped infrastructure outside Bratislava. In addition, Slovakia has experienced a drastic slowdown in productivity growth since the global financial crisis, due in part to its aging workforce.

\section{Executive Board Assessment}

In concluding the 2017 Article IV consultation with Slovak Republic, Executive Directors endorsed staff's appraisal as follows:

Slovakia continues to enjoy strong economic growth. Real incomes are now more than 70 percent of the EU average. Rising employment and real wages supported estimated GDP growth of 3.3 percent in 2016. Similar growth is forecast for 2017 due, in part, to a rebound in EU funds absorption. Planned investment in the automotive sector is projected to drive growth in the medium term.

Risks to the optimistic outlook are primarily external. The United Kingdom's planned exit from the European Union and elections in Europe's larger economies create some uncertainty about growth prospects in Slovakia's key trading partners. Continued rapid growth in credit to households, following several years of double-digit increases, is a potential domestic risk.

An aging population and sharp regional disparities are key long-term challenges. Productivity growth has nearly halved since 2008 . With its population aging the fastest in Europe, a further slowdown in productivity is likely unless countered by structural reforms. At the same time, the Bratislava region has captured the lion's share of Slovakia's past economic success. Underdeveloped infrastructure, lower educational attainment, and limited labor mobility have held back the Eastern and Central regions.

The authorities' planned fiscal consolidation is appropriate and can create space for addressing regional inequities and future aging-related spending. It is important to identify clear measures to meet the balanced budget objective by 2019. On current policies, the fiscal deficit is likely to be 0.7 percent of GDP in 2019. To close the gap, the authorities should save in whole or in part expenditure reductions identified in current spending reviews, and increase VAT and corporate tax efficiency by implementing a compliance strategy that targets tax evaders. In addition, further fiscal space should be created by raising property and environmental tax collections to preserve public investment.

To safeguard the stability generated by the FRA, Slovakia's fiscal anchor, debt rules and brakes should not be modified to provide more favorable treatment of any specific type of investment. To strengthen cash management, modifications to allow for government cash balances to be netted out from gross debt can be considered when assessing performance relative to the debt ceiling: the current ceiling on gross debt discourages pre-financing efforts during periods of low interest rates even when these have no impact on net debt. However, 
the introduction of any escape clause for investment spending should be avoided to allow the budget process to remain a forum for assessing the relative merits of competing demands for government spending. Staff also recommends keeping the debt limits and brakes at their current levels.

Unwavering implementation of approved pension reforms is imperative to help contain agerelated spending. The politically-costly and significant pension reforms undertaken in 2012, including indexing benefits to inflation, will pay off only if implemented in full. In addition, re-opening Pillar II should be avoided. Other measures such as indexing accrued pension benefits to inflation or broadening the social contribution base would yield further savings. In the health sector, current efforts to centralize procurement and restructure the hospital network should be advanced.

Continued regulatory and supervisory vigilance would help preserve the stability and health of Slovakia's banking system. Slovakia's banks are profitable, well-capitalized, and possess healthy balance sheets. Looking ahead, profit pressures stem from tight interest margins and the burden of the special levy on bank profits. In addition, bank exposure to Slovakia's households, which are among the most indebted in central and eastern Europe, has grown rapidly. The authorities have made good pre-emptive use of micro- and macro-prudential measures such as introduction of tighter loan-to-value (LTV) ratios and introduction of a systemic risk buffer in 2017. However, further steps may be necessary to maintain credit quality in the current environment of high credit growth. Specifically, the authorities should consider imposing higher risk weights on riskier mortgage loans, lowering the maximum LTV ratio, and reducing the bank tax as originally planned.

To support productivity growth and sustain convergence, measures to improve labor market efficiency and the business environment are needed. The shift in active labor market policies (ALMP) toward activities that move the long-term unemployed into the labor market are welcome. Successful implementation of recommendations from the ongoing expenditure review of ALMP will be important to maximize benefits. In the near term, a review and possible relaxation of the process for granting work permits to foreign workers could help ease the growing skills mismatch. In the long run, revamping education policies to strengthen vocational training will be needed to ensure a better match of labor supply and demand. Beyond the labor market, tackling the widespread perception of corruption in Slovakia will require steps to improve judicial transparency and independence and the assiduous implementation of recent measures to curb unethical behavior in government.

Implementing a comprehensive strategy to improve economic outcomes in underdeveloped regions is also essential to boost growth and equity. Effective and timely absorption of EU funds can help address shortcomings. The focus needs to be on identifying priority infrastructure projects that facilitate further investment and labor mobility in under-developed regions, establishing clear selection criteria and following a competitive 
procurement process. The authorities' recent initiatives to create jobs in the lagging regions through an integrated approach of working with local businesses, communities and government is welcome. 


\begin{tabular}{l}
$2015 \quad 2016 \quad 2017 \quad 2018$ \\
\cline { 3 - 5 }
\end{tabular}

National income, prices and wages (Annual percentage change)

Real GDP

Inflation (HICP)

Inflation (HICP, end of period)

Employment

Public finance, general government (Percent of GDP)

Revenue

Expenditure

Overall balance

General government debt

Monetary and financial indicators (Percent)

Credit to private sector (Growth rate)

Lending rates ${ }^{1}$

Deposit rates $^{2}$

Government 10-year bond yield

Balance of payments (Percent of GDP)

Trade balance (Goods)

Current account balance

Gross external debt

$\begin{array}{rrrr}3.8 & 3.3 & 3.3 & 3.7 \\ -0.3 & -0.5 & 1.2 & 1.5 \\ -0.5 & 0.2 & 1.5 & 1.6 \\ 2.0 & 2.5 & 3.0 & 1.1\end{array}$

$\begin{array}{llll}42.6 & 39.8 & 39.9 & 40.1\end{array}$

$\begin{array}{llll}45.3 & 41.8 & 41.7 & 41.2\end{array}$

$\begin{array}{llll}-2.7 & -2.0 & -1.8 & -1.1\end{array}$

$52.5 \quad 52.5 \quad 52.2 \quad 51.1$

$\begin{array}{rrrr}12.3 & 9.1 & 7.5 & 6.5 \\ 3.1 & 2.6 & \ldots & \ldots \\ 1.0 & 0.6 & \ldots & \ldots \\ 0.9 & 0.5 & 0.8 & 1.2\end{array}$

$\begin{array}{rrrr}2.7 & 4.3 & 3.6 & 3.6 \\ 0.2 & 0.9 & 0.7 & 0.6 \\ 85.4 & 84.9 & 84.8 & 82.7\end{array}$

Sources: National Authorities; and IMF staff projections.

${ }^{1}$ Average of interest rates on new housing loans to households and loans of less than EUR 1 million to nonfinancial corporations (all maturities).

${ }^{2}$ Average of interest rates on new deposits with agreed maturity (up to 1 year) from households and nonfinancial corporations. 


\section{INTERNATIONAL MONETARY FUND}

\section{SLOVAK REPUBLIC}

\section{STAFF REPORT FOR THE 2017 ARTICLE IV CONSULTATION}

February 23, 2017

\section{KEY ISSUES}

Context: Slovakia is an economic success story. Sustained convergence since 1995 has lifted real per capita GDP to over 70 percent of the European Union average. The postcrisis recovery has been one of the most robust in Europe and GDP growth is projected to pick up further in the medium term, in part from additional foreign investment in the automotive industry. However, with regional disparities and aging pressures among the most severe in Europe, significant challenges remain. The banking sector also faces vulnerabilities from very high exposure to the real estate sector.

\section{Key Policy Recommendations}

Fiscal Policy. In light of the closed output gap, the authorities' plan to reach a balanced budget by 2019 is appropriate. To ensure this outcome, enhancing revenue and expenditure efficiencies is recommended. Further fiscal space should be created via broadening of the tax base to preserve public investment. Staff recommends keeping the debt limits and brakes at their current levels. In particular, debt limits and brakes should not be modified with the objective of affording more favorable treatment to any particular category of spending, including infrastructure investment. The authorities undertook significant pension reforms in 2012. Steady implementation of these reforms is imperative to ensure long-run fiscal sustainability.

Financial Policy. A prolonged period of strong household credit growth funded by domestic deposits reflects financial deepening; however, vulnerabilities are building up. Staff supports the authorities' recent tightening of macro-prudential policies aimed at preventing the erosion of lending standards and increasing banks' buffers. Further measures are encouraged to increase the risk weights on mortgage loans with high loan-to-value ratios and reduce the maximum loan-to-value limit.

Structural Policies. To sustain convergence and ensure more inclusive growth, structural policies should tackle high regional disparities, skills shortages, and slowing productivity growth. This will require: (i) a more efficient absorption of EU cohesion funds to improve infrastructure and educational attainment in less developed regions; (ii) active labor market policies that invest more in skills training to prevent the inactivity trap; (iii) less cumbersome procedures to import skilled labor; and (iv) implementation of anti-corruption measures and judiciary reforms to ensure a more predictable business environment. 
Approved by Philip Gerson and Zeine Zeidane
Discussions were held in Bratislava during January 23-February 2, 2017. The mission met with Finance Minister Kažimír, NBS Governor Makúch, the Fiscal Council, other senior officials, private sector representatives, trade unions, and local government officials in Eastern Slovakia.

The staff team comprised Ms. Rahman (head), Ms. Yackovlev, Mr. Ralyea and Ms. Caselli. Ms. Erbenova (OED) and Mr. Hagara (OED) attended policy meetings. Ms. Calixto and Mr. Smith assisted in the preparation of the staff report.

\section{CONTENTS}

A. Fiscal Policy: Creating Space to Address Regional Disparities and Aging Pressures

B. Financial Sector Policies: Sustaining Financial Deepening without Jeopardizing Stability

\section{BOXES}

1. Regional Disparities $\underline{5}$

2. Risk Assessment Matrix 9

3. Implementation of IMF Policy Advice $\underline{15}$

\section{FIGURES}

1. Real Sector Developments, 2010-16 $\underline{25}$

2. Labor Market Developments, 2010-16__ 26

3. Fiscal Developments, 2010-16__ 27

4. Financial Sector Developments, 2010-16__ $\underline{28}$

5. External Sector Developments, 2010-16 __ 29

\section{TABLES}

1. Summary of Economic Indicators, 2014-2022 $\underline{30}$

2A. Statement of Operations of the General Government, 2014-2022 (Millions of euros) $\underline{31}$

2B. Statement of Operations of the General Government, 2014-2022 (Percent of GDP) $\underline{32}$ 
3. General Government Balance Sheet, 2009-2015 __ $\underline{33}$

4. Balance of Payments, 2014-2022__ 34

5. Financial Soundness Indicators for the Banking Sector, 2010-2016___ 35

\section{ANNEXES}

I. Labor Productivity: Developments and Outlook

II. Assessment of External Stability, Competitiveness and Vulnerabilities

III. Public Debt Sustainability Analysis (DSA) 


\section{CONTEXT}

1. The Slovak economy has seen strong and sustained convergence. Real GDP per capita increased from around 45 percent of the European Union (EU) average in 1997 to over 70 percent in 2015. Productivity growth in the manufacturing sector, which has strong links to global supply chains, has been a key driver of this convergence. Although growth has eased in the post-crisis years, Slovakia's recovery has been among the strongest in the Euro area (EA) with real GDP and its components now above their pre-crisis levels.

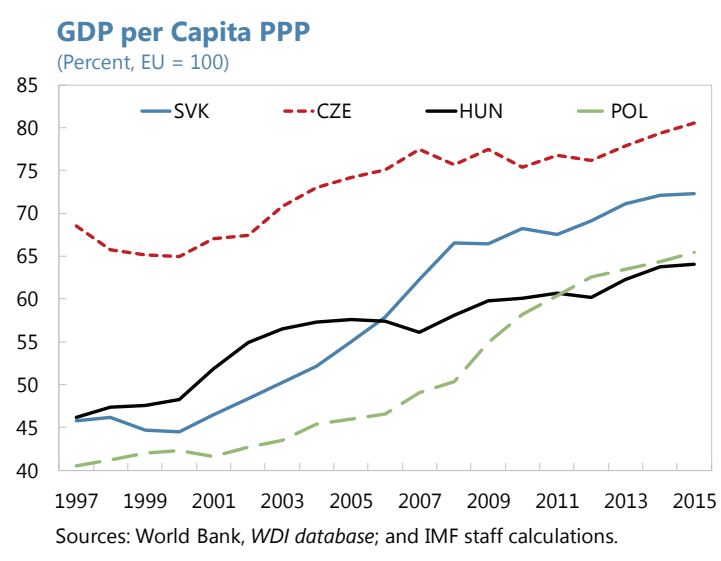

2. However, economic prosperity has not been evenly shared across regions. In fact, as measured by the Gini coefficients, Slovakia shows the highest regional disparities among EU countries. Although all regions have seen declining unemployment and some increase in per capita income over the last decade, gains have been heavily concentrated in the Bratislava region (Box 1). Unemployment rates in Eastern and Central Slovakia are about three times as high as in the Bratislava region, which also enjoys a much higher per capita income. Lower educational attainment and underdeveloped infrastructure explain much of these disparities. An estimated 1.1 million people, roughly a fifth of the population and mostly concentrated in lagging regions, are considered at risk of poverty or social exclusion.

\section{Meanwhile, productivity growth has}

slowed. While this is to some extent a global phenomenon, concerns in Slovakia are particularly acute as the economy faces significant further headwinds from aging of both the population and the workforce. Labor productivity growth, which was the engine of pre-crisis output growth, is estimated to have nearly halved during 2009-2015 due to lower total factor productivity (TFP) growth and capital deepening (Annex I). With the increase in Slovakia's old age dependency ratio projected to be the largest in the EU, a further slowdown in productivity growth is likely. Sustaining

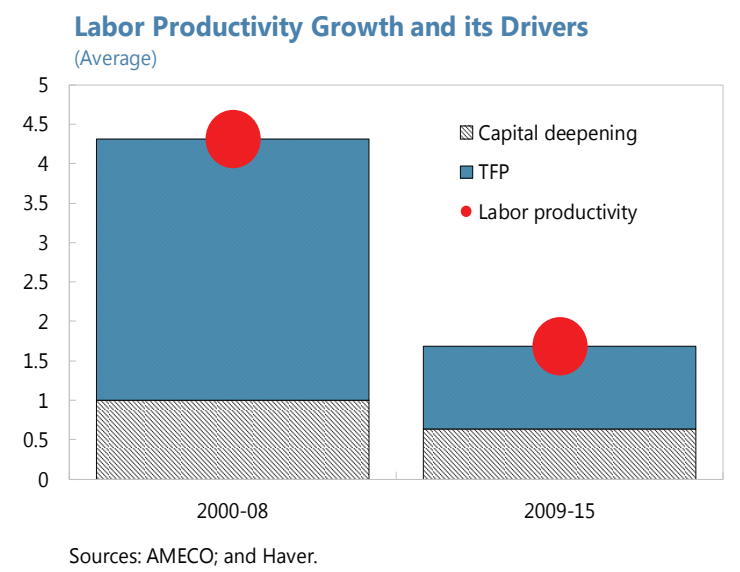
convergence at its current pace may therefore prove challenging in the long run. 


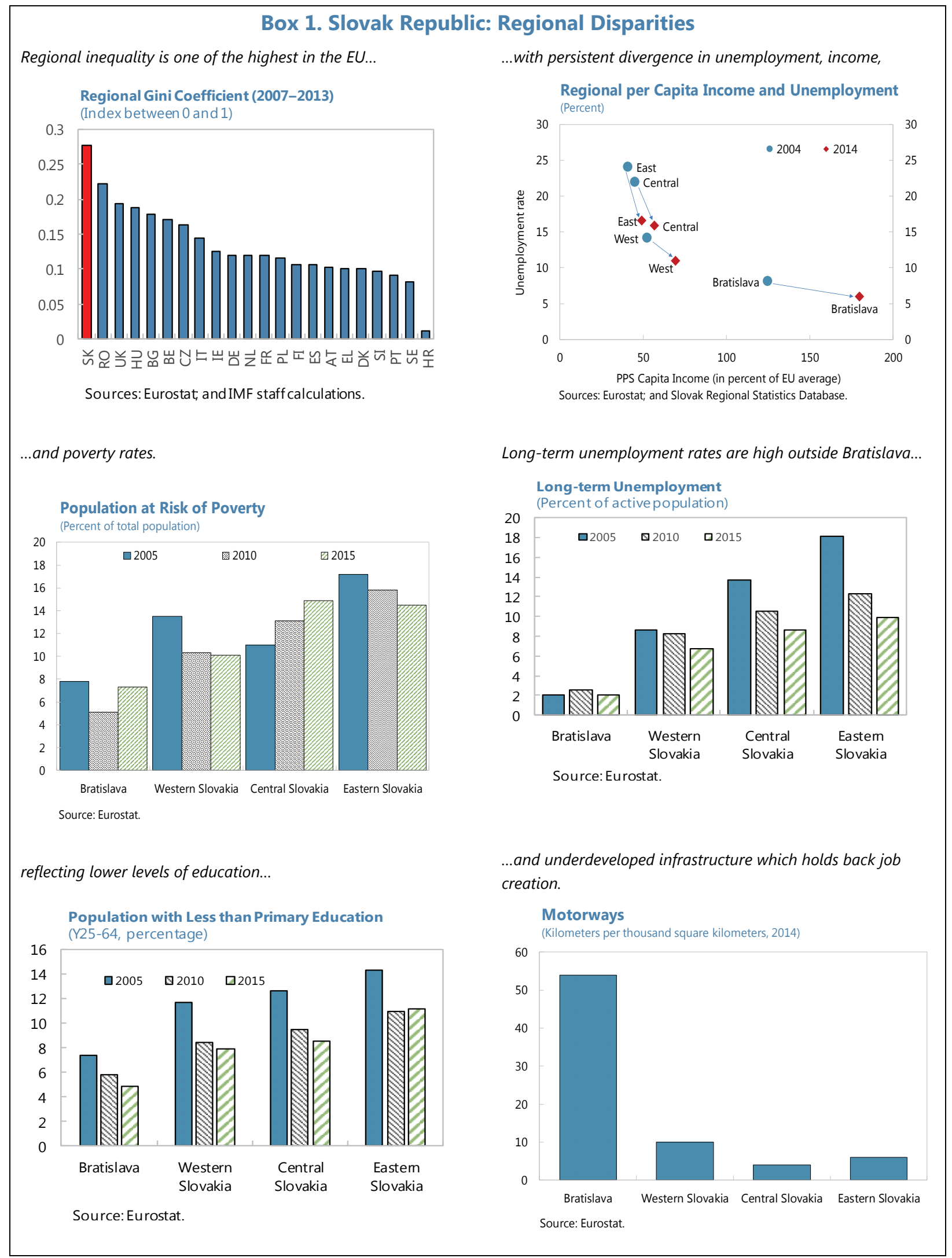




\section{RECENT DEVELOPMENTS}

4. Broad-based economic growth continues. After picking up in 2015, thanks to the exceptionally high absorption of EU funds at the end of the 20072013 programming period, real GDP growth is projected to moderate in 2016 but remain robust at 3.3 percent. Growth continues to benefit from an improving labor market, low inflation and strong household credit growth. Headline inflation has been negative since 2014, while core inflation has hovered around zero (Figure 1, Table 1). The output gap is now closed.

\section{Steady growth in employment has brought} the unemployment rate below its pre-crisis level

(Figure 2). While high structural unemployment and a segregated labor market has kept the overall unemployment rate elevated, there are clear signs of labor market tightening. Real wage growth recently surpassed productivity growth and the number of firms indicating labor shortages as a factor limiting production is now back to its pre-crisis level. Labor shortage is particularly acute for skilled workers in the manufacturing sector.

\section{The headline fiscal deficit improved to} 2 percent of GDP in 2016. The consolidation of 0.7 percent of GDP was largely driven by a sharp drop in capital spending reflecting the end of the EU programming period but also lower interest payments and goods and services spending (Table 2B). On the revenue side, an improving labor market, some efficiency gains, and legislative changes boosted tax revenues and social contributions, but a sharp drop in EU funds resulted in a decline in overall revenues. The cyclically-adjusted structural fiscal balance also improved in 2016 after remaining broadly neutral in recent years. Sovereign risk spreads remain historically low and were largely unaffected by both Brexit and the emerging market sell-off that followed the US elections (Figure 3).

\section{Private sector credit growth has been among the highest in the EU (text chart). Falling} interest rates on mortgage loans, the robust labor market recovery, and legislative changes imposing limits on early mortgage repayment fees have sustained double-digit growth in household credit, which now accounts for about two-thirds of the outstanding private sector credit stock 
(Figure 4). House prices have increased in some regions but remain below their pre-crisis levels. The rate of growth of credit to nonfinancial corporations (NFC), at 6 percent, is one of the highest in EU countries. In 2016, NFC credit experienced more broad-based growth with some easing in credit conditions.

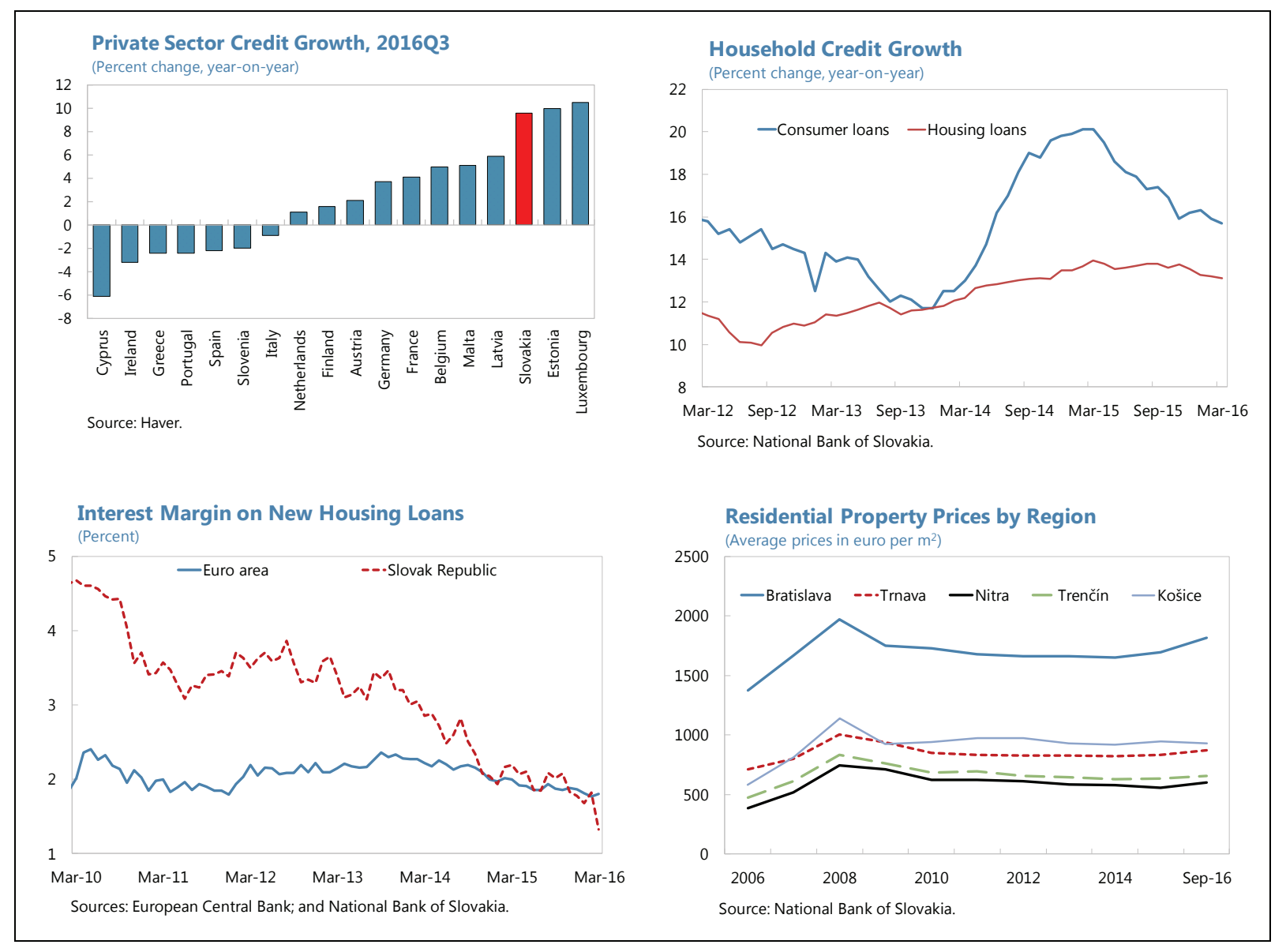

8. External sector developments have been favorable and are in line with fundamentals

(Annex II). Export volume has nearly doubled since the post-crisis dip, reflecting rising market shares in the EU (Figure 5). Robust exports, together with low oil prices, have generated trade surpluses since 2012, albeit with some recent weakening. The current account in 2016 is estimated to have recorded a surplus of 0.9 percent of GDP, owing to lower imports linked to the slowdown in EU funds related investments. The external stability assessment shows the external position to be broadly in line with fundamentals. Given the likely negative impact of population aging on the fiscal balance, a small current account surplus seems prudent. External debt, which is denominated in euros and mostly composed of long-term general government bonds, declined to slightly below 85 percent of GDP in 2016 (Table 4).

\section{OUTLOOK AND RISKS}

9. GDP growth is projected to pick up in the medium term. Benefitting from investments by Jaguar Land Rover (JLR) and Volkswagen (VW), real GDP growth is projected to peak at 3.9 percent 
in 2019 and settle at around 31/2 percent thereafter. The new automotive investments are expected to increase Slovakia's car production by 40 percent in the medium term. The current account surplus is expected to rise after the import-intensive initial phase of these investments. Reflecting strong growth and current account surpluses, external debt is projected to decline to 74 percent of GDP by 2022. Inflation is projected to reach 2 percent at the end of the medium term, reflecting higher energy prices and strong household consumption.

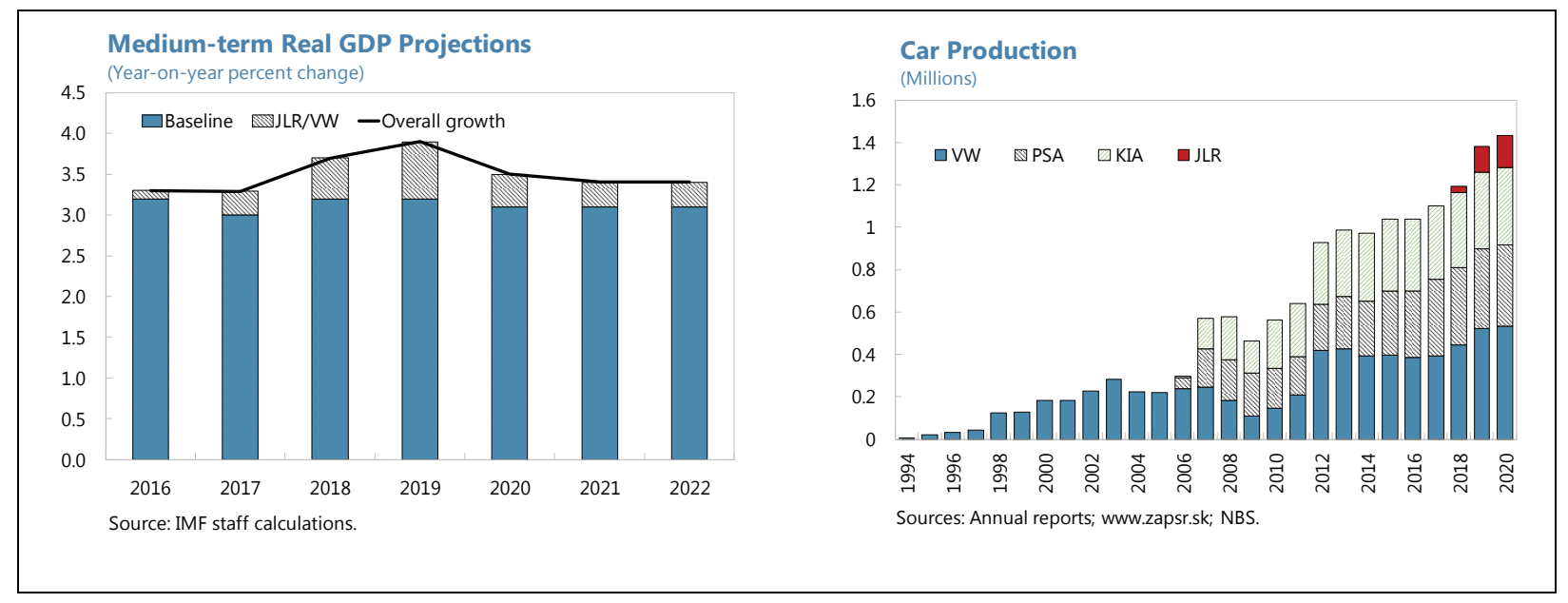

10. Developments in Europe and key export markets constitute the main external risks (Box

2). Slovakia has strong real and financial links with a small number of central and western European countries. In addition, its export structure is highly concentrated, with transport and machinery products accounting for more than half of exports (Annex II). The United Kingdom's exit from the EU poses large uncertainties and risks of negative spillovers from lower growth in key trading partners. Europe's political calendar, with elections in the Netherlands, France, and Germany in 2017, adds to this uncertainty. Moderate public indebtedness and low financing needs along with strong external fundamentals provide some cushion against possible Top Five External, Real and Financial Links 1/ (Percent of total)

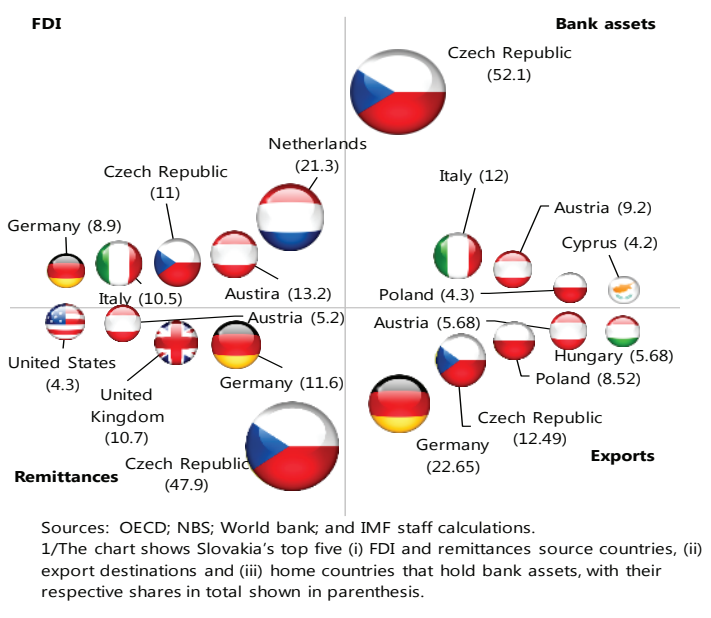
external shocks. The rapid growth of credit to households is a potential domestic risk, particularly if the labor market falters following a negative external shock.

11. The authorities broadly concurred with staff's economic outlook and risks. They foresee more robust medium-term growth with an acceleration in 2018 and 2019. The authorities agreed that the main risks arise from developments in key trading partners in Europe. They also saw increasing protectionism and uncertainties related to the new US administration as risks. They viewed spillovers from Brexit as likely to be contained. Any major distress in European banks as well as a possible rise in geopolitical tensions in the region pose downside risks affecting Slovakia 
indirectly through their impact on major trading partners. The authorities agreed that the real exchange rate is in line with economic fundamentals.

\begin{tabular}{|c|c|c|c|c|c|}
\hline \multicolumn{6}{|c|}{ Box 2. Risk Assessment Matrix ${ }^{1}$} \\
\hline & Source of Risks & Likelihood & $\begin{array}{c}\text { Time } \\
\text { Horizon }\end{array}$ & Impact & Policy Response \\
\hline \multirow{3}{*}{$\begin{array}{l}\overline{0} \\
\text { 은 }\end{array}$} & $\begin{array}{l}\text { Weaker-than-expected } \\
\text { global growth, } \\
\text { including significant } \\
\text { slowdown in EMs and } \\
\text { structurally weak } \\
\text { growth in key advanced } \\
\text { countries }\end{array}$ & Medium /High & $\begin{array}{l}\text { Short to } \\
\text { Medium } \\
\text { Term }\end{array}$ & $\begin{array}{l}\text { Medium /High } \\
\text { Weaker EM/China growth } \\
\text { would be primarily felt } \\
\text { indirectly, to the extent key } \\
\text { trading partners are affected. } \\
\text { Exports and growth would be } \\
\text { strongly hit by a slowdown in } \\
\text { Europe, especially Germany. } \\
\text { Debt ceilings could be } \\
\text { breached in the event of a } \\
\text { large adverse growth shock. } \\
\text { Weaker growth and higher } \\
\text { unemployment would worsen } \\
\text { banks' assets qualities. }\end{array}$ & $\begin{array}{l}\text { Medium-term: Diversify export } \\
\text { destinations, increase high value-added } \\
\text { exports. } \\
\text { Near-term: Create fiscal space through } \\
\text { efficiency-based consolidation, } \\
\text { broadening of the tax base, and keeping } \\
\text { debt limits at their current levels (see } \\
\text { discussion in Section B). } \\
\text { Improve labor market and business } \\
\text { environment to boost productivity and } \\
\text { potential output (see discussion in } \\
\text { Section C). } \\
\text { Draw on banks' capital buffers. }\end{array}$ \\
\hline & $\begin{array}{l}\text { Retreat from cross- } \\
\text { border integration, } \\
\text { policy and geopolitical } \\
\text { uncertainties, including } \\
\text { those related to post- } \\
\text { Brexit arrangements } \\
\text { and upcoming elections } \\
\text { in Europe }\end{array}$ & Medium /High & $\begin{array}{l}\text { Short to } \\
\text { Medium } \\
\text { Term }\end{array}$ & $\begin{array}{l}\text { Medium/High } \\
\text { Slovakia's exports and growth } \\
\text { could be negatively affected by } \\
\text { rising protectionism. } \\
\text { Direct links to the UK are } \\
\text { limited, but potential negative } \\
\text { spillovers could materialize. }\end{array}$ & $\begin{array}{l}\text { Medium-term: Diversify exports products } \\
\text { and destination, and increase value } \\
\text { added in exports. } \\
\text { Near-term: Create fiscal space through } \\
\text { efficiency-based consolidation, } \\
\text { broadening of the tax base and keeping } \\
\text { the debt ceiling at their current levels. } \\
\text { Improve labor market and business } \\
\text { environment to attract new and more } \\
\text { diversified FDI. }\end{array}$ \\
\hline & $\begin{array}{l}\text { Financial conditions } \\
\text { Significant further } \\
\text { strengthening of the } \\
\text { US dollar and/or } \\
\text { higher rates } \\
\text { - European bank } \\
\text { distress }\end{array}$ & Medium /High & $\begin{array}{l}\text { Short } \\
\text { Term }\end{array}$ & $\begin{array}{l}\text { Low } \\
\text { A depreciation of the euro } \\
\text { could positively impact exports } \\
\text { and the external debt } \\
\text { A possible distress in European } \\
\text { banks may indirectly affect } \\
\text { growth via spillovers from } \\
\text { trading partners. }\end{array}$ & $\begin{array}{l}\text { Continue to monitor financial } \\
\text { developments. } \\
\text { - Use active debt management to pre- } \\
\text { finance fiscal needs. }\end{array}$ \\
\hline ฮ్త & $\begin{array}{l}\text { Property market } \\
\text { downturn in the event } \\
\text { of a worsening } \\
\text { economic situation }\end{array}$ & Low & $\begin{array}{l}\text { Medium } \\
\text { Term }\end{array}$ & $\begin{array}{l}\text { Medium } \\
\text { Weakening of banks' balance } \\
\text { sheets }\end{array}$ & $\begin{array}{l}\text { Use macro-prudential toolkit and closely } \\
\text { supervise lending practices. }\end{array}$ \\
\hline \multicolumn{6}{|c|}{$\begin{array}{l}\text { 1The Risk Assessment Matrix (RAM) shows events that could materially alter the baseline path (the scenario most likely to materialize in the view of IMF staff). The } \\
\text { relative likelihood is the staff's subjective assessment of the risks surrounding the baseline ("low" is meant to indicate a probability below } 10 \text { percent, "medium" a } \\
\text { probability between } 10 \text { and } 30 \text { percent, and "high" a probability between } 30 \text { and } 50 \text { percent). The RAM reflects staff views on the source of risks and overall level of } \\
\text { concern as of the time of discussions with the authorities. Non-mutually exclusive risks may interact and materialize jointly. "Short term" and "medium term" are meant } \\
\text { to indicate that the risk could materialize within } 1 \text { year and } 3 \text { years, respectively. exclusive risks may interact and materialize jointly. "Short term" and "medium term" } \\
\text { are meant to indicate that the risk could materialize within } 1 \text { year and } 3 \text { years, respectively. }\end{array}$} \\
\hline
\end{tabular}




\section{POLICY DISCUSSION}

\section{A. Fiscal Policy: Creating Space to Address Regional Disparities and Aging Pressures}

\section{Background}

12. The 2017-19 medium-term budget sets an ambitious fiscal consolidation path. The government targets an overall deficit of 1.3 percent of GDP in 2017, and a balanced budget by 2019. The consolidation is entirely on the expenditure side as overall revenues are projected to decline in percent of GDP due to lower grants and others revenues despite a set of measures yielding small gains. On the expenditure side, declining unemployment and recent pension reforms are projected to contain growth in

Authorities' Planned Fiscal Consolidation and Sources (Percent of GDP) ${ }^{1}$

\begin{tabular}{lrrr}
\hline & 2017 & 2018 & 2019 \\
\hline Target fiscal consolidation & 0.7 & 0.9 & 0.6 \\
Revenue measures & 0.2 & 0.1 & -0.9 \\
Tax revenues & 0.1 & -0.1 & -0.1 \\
Grants and other revenues & 0.0 & 0.2 & -0.7 \\
Social contributions & 0.1 & -0.1 & -0.1 \\
Expenditure measures & 0.4 & 0.8 & 1.5 \\
Wages and compensation & 0.2 & 0.0 & 0.1 \\
Use of goods and services & -0.1 & 0.4 & 0.2 \\
Social benefits & 0.4 & 0.4 & 0.4 \\
Other expenses & -0.3 & -0.1 & 0.0 \\
Net acquisition of non-financial assets & 0.2 & 0.1 & 0.8 \\
\hline Sources: National Authorities; and IMF staff estimates. & & \\
${ }^{1}$ Notes: Reflects the authorities' planned fiscal consolidation path based on data in millions of euros provided to IMF staff \\
on January 9, 2017, and calculated in percent of GDP as projected by IMF Staff (see Table 1).
\end{tabular}

social spending. The authorities also project a further decline in capital spending based on lower EU funds absorption which is the main financing source of public investment.

\section{Recent policy efforts have targeted improvement of revenue and expenditure}

efficiencies. Measures targeting tax fraud and non-compliance have reduced the VAT gap, but at 48 percent, the efficiency gap (mostly concentrated in construction, trade and transportation sectors) is high relative to that of EU peers. The efficiency is also low for the CIT and, possibly, for the mineral oils excise tax, where the effective tax rate remains low compared to its pre-crisis level. On the expenditure side, the Slovak authorities initiated in 2015 a rolling series of thematic expenditure reviews called the "Value for Money" program, which are planned over a four-year period and cover one-quarter of central government spending each year. The first set of reviews, covering health, transport and IT spending, identified measures for cost savings of around 9-10 percent in the areas of health and IT spending (about 0.2 percent of GDP annually each). The authorities have launched the next set of reviews in the areas of education, social benefits and the environment. The idea behind this program is to identify opportunities to increase resource efficiency and in turn reallocate savings within each ministry, rather than to reduce total expenditure. 


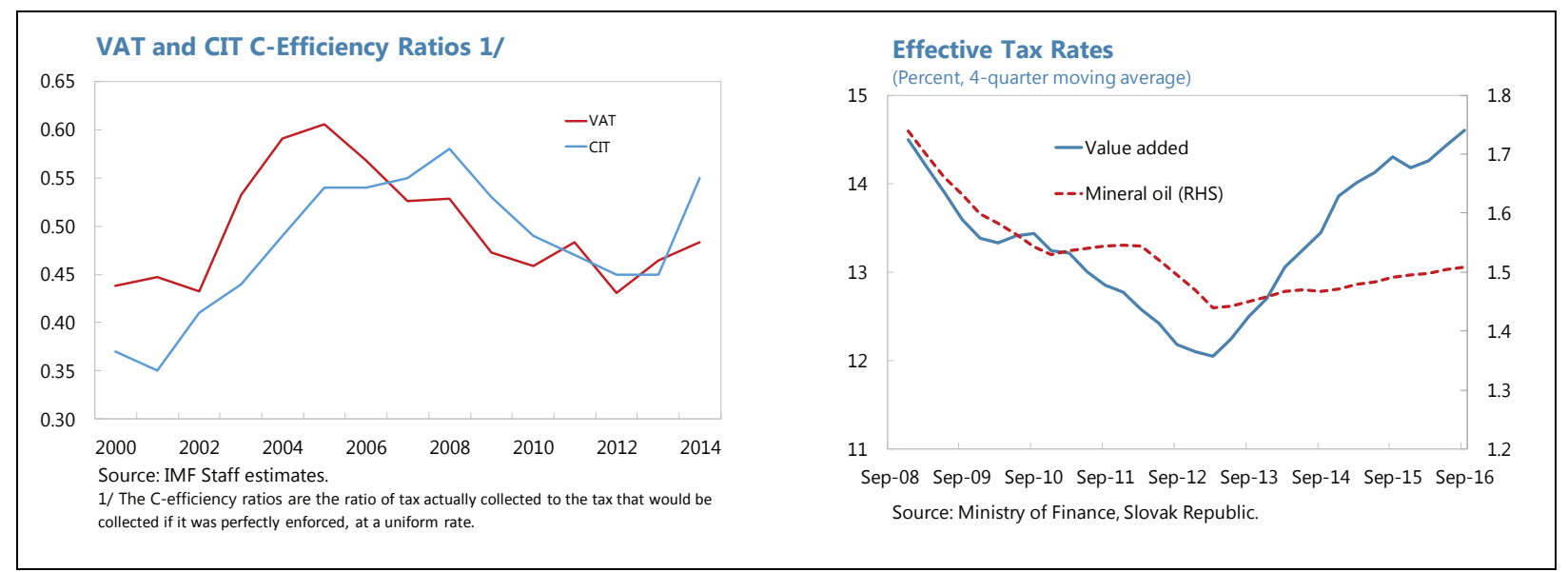

14. With moderate public debt, and a current account surplus, Slovakia would appear to have adequate fiscal space, but there are also significant spending needs in the medium term. Slovakia's road infrastructure, which is sub-par relative to its peers, hampers connectivity across and within regions, fostering regional disparities and labor market segmentation. In addition to the resources currently available for transportation investment from EU funds (3.6 billion euro or 4 percent of GDP for the 2014-2020 programming period), the authorities estimate additional infrastructure investment needs to be around 6-8 percent of GDP. However, the limited capacity to spend the sizable EU funds already allocated for infrastructure call for caution in increasing domestically-financed infrastructure spending before further improving the public investment management framework (see paragraph 18). In addition, the authorities anticipate a need for higher domestic outlays in the long run and especially for the period when Slovakia may not have access to EU funding. A significant increase in education spending is also likely needed to improve the quality of education, which shows deficiencies with respect to OECD and EU peers, and enhance labor skills which, in a growing number of cases, do not meet employers' needs. Staff deems crafting a comprehensive plan to address these weaknesses a priority, and higher spending should only commence once such a plan is put in place.

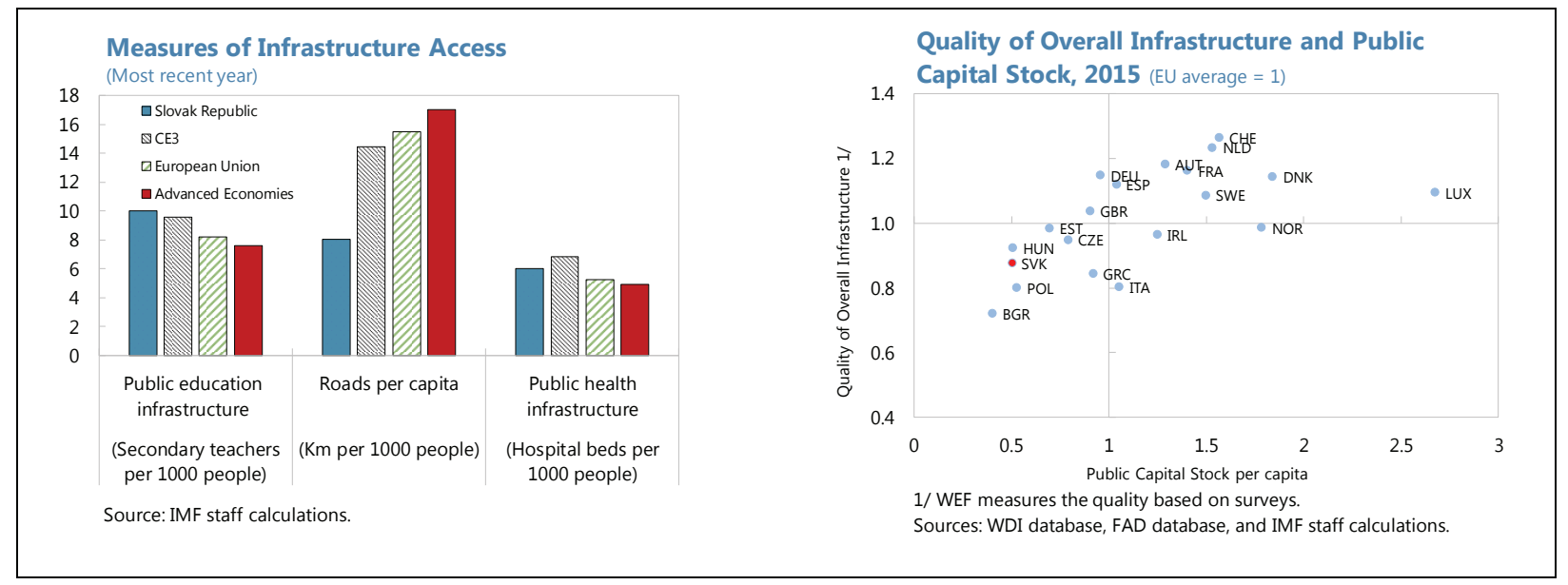

15. In addition, Slovakia is also set to experience an increase in aging-related social spending. The authorities undertook significant pension reforms in 2012 that include linking the 
retirement age to life expectancy, unifying male/female retirement age by 2022 , and indexing benefits to price increases only. Benefiting from these reforms, pension spending is projected to decline until 2035 but rise thereafter. Taking into account both pension and health and long-term care spending, a cumulative increase in aging-related public expenditure of 21.5 percent by 2060 (about 4 percent of GDP) is projected under the baseline scenario. A higher increase is possible if TFP grows at the rate of historical average or slows down further due to workforce aging and if the authorities reopen Pillar II, $^{1}$ which the authorities have done four times. Each reopening has increased the future obligations of Pillar I as participants left Pillar II without penalty and are entitled to full benefits under the Pillar I system. Such openings in the future pose risks to rising spending from Pillar I.

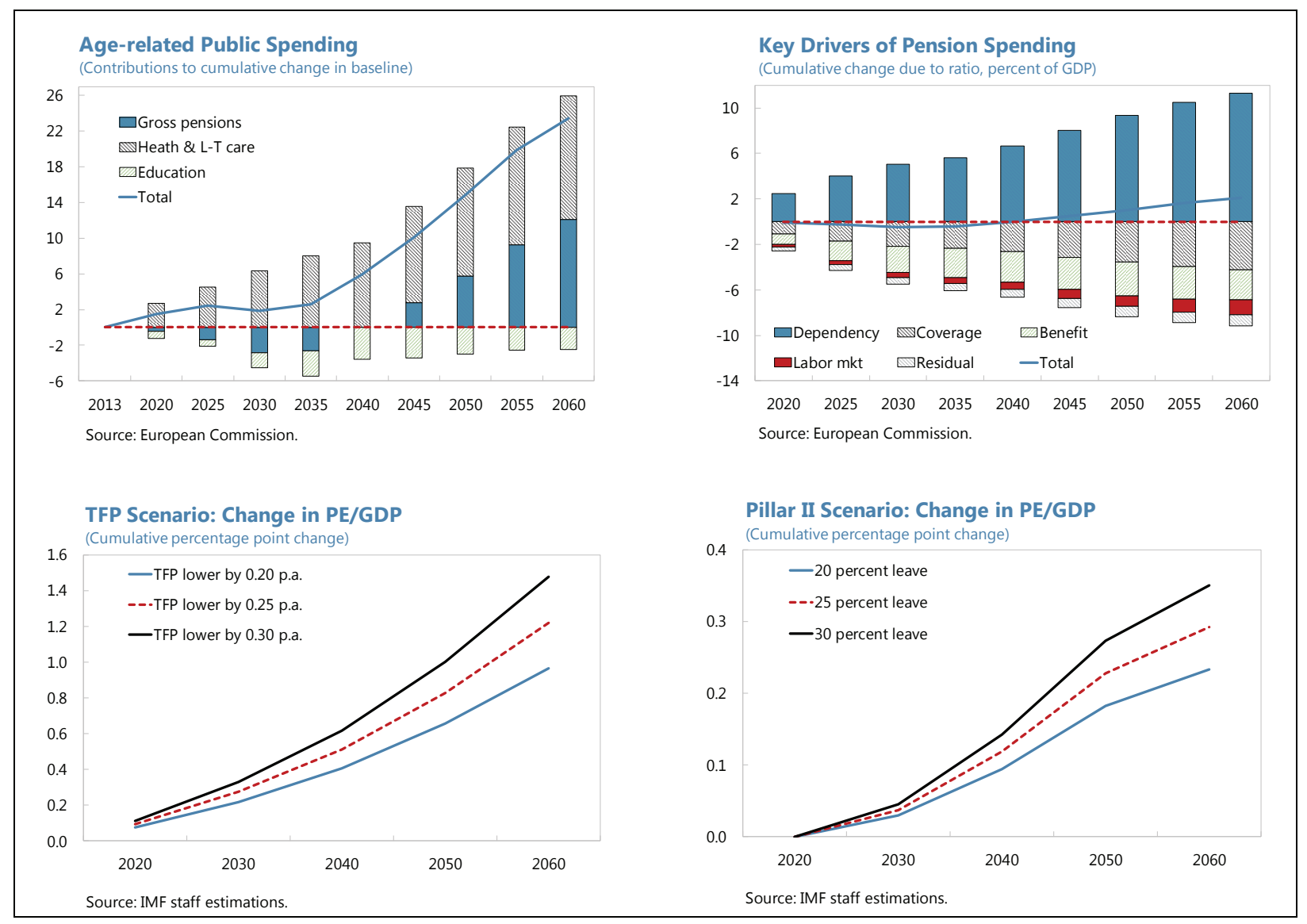

\section{Discussion}

16. In light of the strong economic momentum and significant long-term needs, staff supports the authorities' objective to achieve a balanced budget by 2019. However,

in the context of wage pressures due a tight labor market, and recent trends in social spending,

\footnotetext{
${ }^{1}$ See Slovakia's Pension and Health Spending: Managing Risks, Selected Issues Paper for more details on these alternative scenarios.
} 
staff's baseline projects a more moderate consolidation with the headline fiscal balance reaching 1.8 percent of GDP in 2017 and -0.7 of GDP in 2019. With a closed output gap, capacity utilization at its pre-crisis high, a tightening labor market, strong credit growth and anticipated large FDI inflows in the medium-term, the proposed efficiency-driven consolidation would not significantly affect growth negatively (text table). On the other hand, fiscal consolidation will help create room for aging-related and future infrastructure spending. To reach a balanced budget in 2019 as intended by the authorities, staff recommends the following measures to improve revenue and expenditure efficiency:

- Increased tax efficiency. Further efforts to increase Slovakia's VAT efficiency to the EU average (54 percent) could produce an additional 0.9 percent of GDP in revenues. The authorities' adoption of 30 additional measures in 2015 encompassing both legal and administrative actions is encouraging and should be complemented by a clear compliance strategy. The establishment of a well-defined corporate income tax base and targeting compliance efforts on the economic sectors with highest evasion rates would further support revenue gains.

- Savings from expenditure efficiency. Staff supports the authorities' "value for money" initiative as a useful initial step to pave the way to a comprehensive spending review. Savings identified through current and future reviews should, at least in part, be used to support the consolidation effort rather than being fully reallocated for spending within the same sector. Establishing clear procedures to support the oversight mandate of the implementation unit, ensuring integration of the measures into the budget, and effective cooperation between ministries are needed to ensure delivery of the identified fiscal savings.

17. In line with past policy advice (Box 3), staff sees the importance of preserving public investment and financing it by raising new revenues through broadening the tax base. There is scope for additional revenues (up to 2 percent of GDP) from reforms to the following taxes: (i) residential property tax, which is levied on surface area as opposed to market valuation; (ii) capital gains tax, which is set to zero for any transaction made after five years of ownership, including the sale of bequeathed properties; and (iii) environmental taxes, where Slovakia has the third-lowest tax collection in the EU. Increasing collections from the property tax, which is widely regarded as an efficient and equitable means of raising revenue with limited adverse effects on economic growth, will create room for higher public investment provided improvements are realized in project preparation and public procurement. This could have a net positive impact on growth in the nearterm and raise potential growth in the medium term.

\section{The authorities' emphasis on infrastructure projects under the 2014-20 EU funds} programming period is appropriate. Priorities include completion of the D1 motorway connecting Bratislava and Kosice as well as improving connectivity within regions. Slovakia receives sizable EU funds (a cumulative 15 percent of GDP between 2007 and 2015) but the allocation does not materially address regional differences. For example, while about one third of EU funds are allocated to transport infrastructure, the share going to Eastern and Central Slovakia remains similar to that dedicated to Bratislava and the West, regions that already enjoy much better infrastructure. This inefficiency is partly created by last-minute, lumpy absorption in favor of shovel-ready projects. Besides strategic selection to improve connectivity, staff's analysis shows that achieving better 
outcomes under the 2014-2020 programming period would require improving expertise and capacity, lowering corruption and preventing frequent changes in legislation, and increasing transparency and competition in public procurement. ${ }^{2}$ Discussions with the private sector and other stakeholders also pointed to a widespread perception of weak procurement processes and a lack of transparency in project selection.

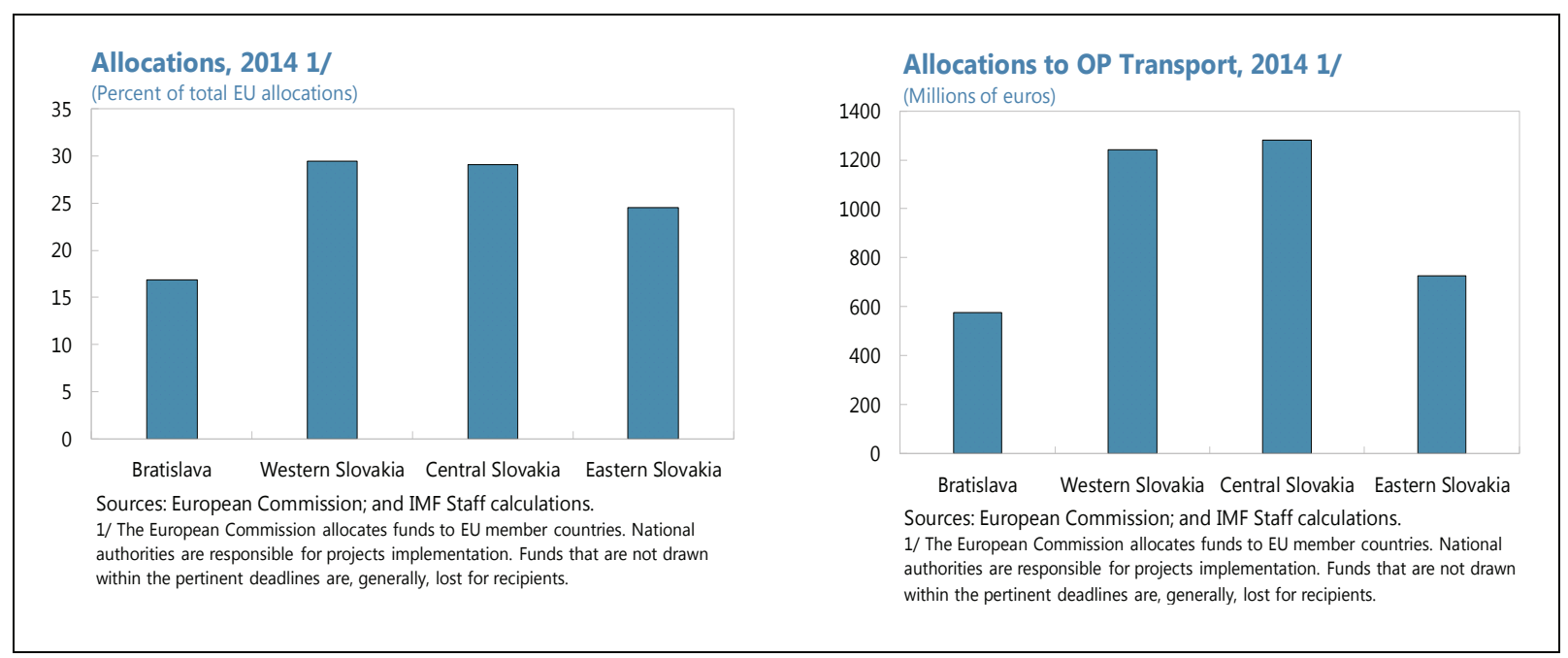

19. The authorities reiterated their commitment to achieving a balanced budget by 2019 .

They expressed their commitment to contain the increase in social spending below that of nominal GDP growth and considered the approved medium-term budget envelope to incorporate reasonably high public wage growth. The authorities are currently contemplating revisions to the Fiscal Responsibility Act (FRA) to incorporate experience from its practical application so far, to allow for increased infrastructure spending and to introduce other changes such as linking the sanction brackets to net public debt rather than gross public debt. While full details of the proposed changes are not yet available, staff supports the netting out of cash balances from the headline debt indicator, to allow for more flexible debt management and further lowering of debt service costs. Staff also recommends keeping the debt limits and brakes at their current levels, and advises that they not be modified to accommodate any specific type of investment, including infrastructure investment. Exempting certain categories of expenditure from counting towards the debt ceiling could create perverse incentives, reduce the effectiveness of the budget as a means of assessing relative efficiencies and resolving competing priorities, and undermine the effectiveness of the debt limit in ensuring fiscal sustainability (which is indeed the objective of the FRA in the first place). ${ }^{3}$

\footnotetext{
2 See EU Funds: Enhancing Absorption to Reduce Regional Disparities Selected Issues Paper.

3 The FRA has four escape clauses: (i) a major recession (a decline in GDP growth rates of at least 12 percentage points over two fiscal years), (ii) a banking sector crisis, (iii) a natural disaster, and (iv) commitments arising from international treaties exceeding three percent of GDP. As discussed in SM/16/13, these existing clauses could benefit from some fine-tuning to reflect the size and nature of shocks faced by Slovakia.
} 


\section{Staff highlighted potential savings from implementing further parametric pension reforms.}

These include linking the
Potential savings in public pension expenditure from further reforms (Percentage points of GDP, 2016-60)

Illustrative potential expenditure savings $1.8-2.8$

Link retirement age more closely to life expectancy $0.6-0.8$

Change in valorization formula (weight CPI at 25 percent)

$1.0-1.5$ Change in calculation of contribution base (annual assessment)

Source: 2015 Ageing Report; IMF staff calculations.

retirement age more closely to life expectancy, changing the valorization formula, and moving the calculation of contribution base to an annual level. The authorities agreed that changing the valorization formula (indexation of accrued pension benefits) could yield signficant savings, but highlighted the need to balance this reform with pension adequacy concerns. They also saw scope for increasing the equity and amount of social contributions by changing to an annual assessment base rather than a monthly one. Staff also urged the authorities to avoid reopening Pillar II. More generally, the authorities acknowledged both upside and downside risks to the baseline pension expenditure forecast and viewed overall fiscal consolidation as the first best approach to prepare for aging pressures. Staff also highilighted the need for continued efforts to centralize health procurement and restructure the hospital system to yield savings.

\section{Box 3. Implementation of IMF Policy Advice}

The track record of the Slovak Republic on implementation of Fund advice is somewhat mixed.

On fiscal policy, the authorities and staff have been in broad agreement on medium-term objectives but differed in their views on the optimal fiscal strategy for achieving those objectives. A tight fiscal stance favored by the authorities is partly motivated by Slovakia's small size, low debt absorption capacity by domestic residents, and the difficulties faced by Euro area countries with high debt. Staff and the authorities have agreed on the need for fiscal consolidation through greater tax and spending efficiency. More meaningful changes to tax policy, such as for property taxation, have been politically challenging to implement. Fiscal consolidation has largely relied on ad-hoc measures and, more recently, on lower capital spending.

On micro- and macro-prudential measures to mitigate the risks from rapid credit growth, staff and the authorities have been closely aligned. Consistent with staff advice, authorities have taken important steps to preserve the credit quality, and create buffers in the financial system. The authorities, however, have decided to not lower the special levy on financial institutions as originally planned despite staff's recommendations.

\section{B. Financial Sector Policies: Sustaining Financial Deepening without Jeopardizing Stability}

\section{Background}

21. The banking sector remains stable but profitability has declined. The share of nonperforming loans, at 4.6 percent, is moderate relative to those of Euro Area (EA) peers. The capital adequacy ratio has remained broadly stable and well above the regulatory minimum with capital 
mostly being Tier 1 (Table 5). Banking sector profitability has declined since mid-2015, driven by a sharp contraction in the net interest margin as well as contributions to regulatory fees. The authorities decided to prolong the special levy on financial institutions at 0.2 percent until 2020, contrary to the previously announced reduction to 0.1 percent once cumulative total receipts reach $€ 750$ million (receipts exceeded $€ 600$ million euros in mid-2016).

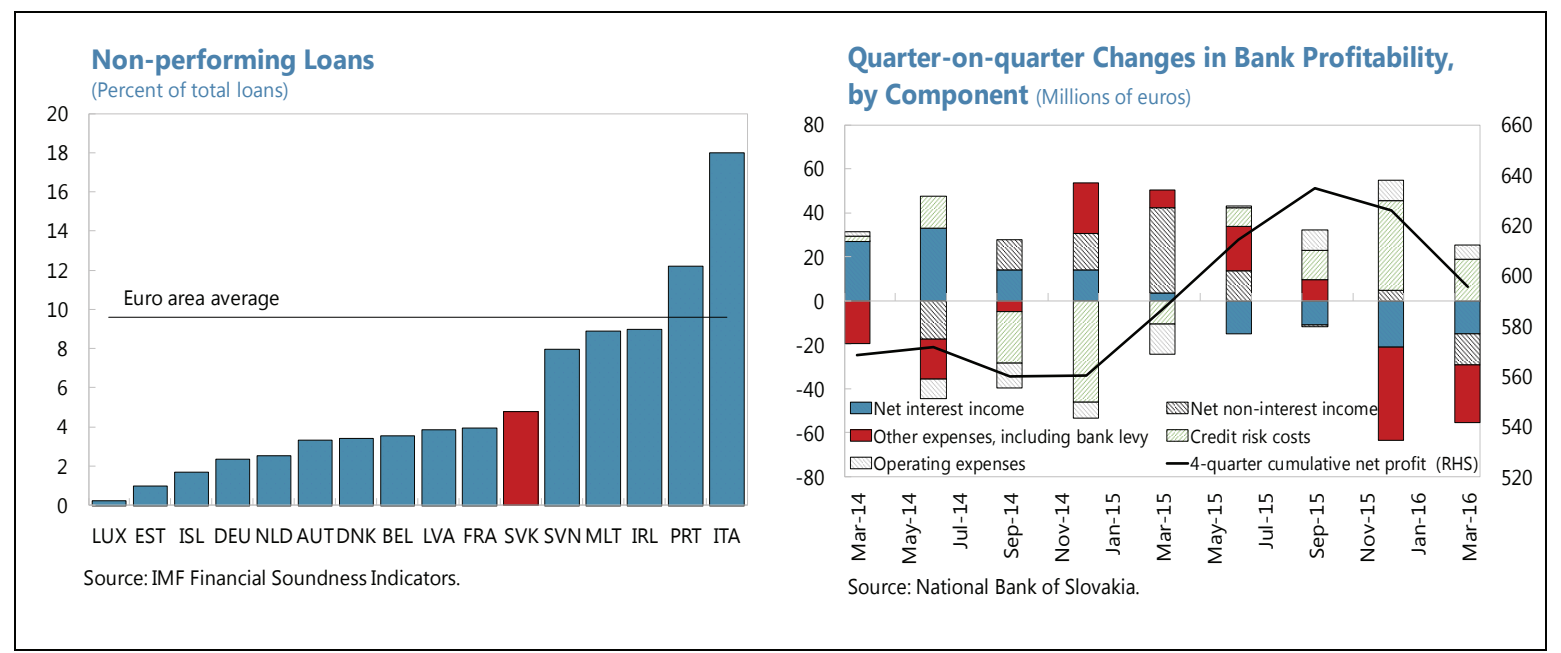

22. However, there are vulnerabilities arising from the very high exposure to the real estate sector. The real estate sector now accounts for over half of total private sector loans. Strong household credit growth has been funded by domestic deposits and mostly reflects financial deepening starting from a low base. However, household indebtedness is now one of the highest among central and eastern European peers. In addition, the underlying quality of the loan portfolio shows some signs of weakening, with an elevated concentration of new loans that have a loan-to-value (LTV) ratio around 90 percent. The share of non-performing loans (NPLs) for consumer loans increased from 7.1 percent in December 2015 to 8.6 percent in December 2016 despite favorable economic conditions and low interest rates. Interest rates on over 80 percent of new mortgage loans are fixed for less than five years with a significant share having 2-3 years until the interest rate reset. These factors make banks vulnerable to interest rate increases and to a slowdown in economic activity.

\section{Slovakia's banking system also has the most pronounced asset liability mismatch in}

the EA. This reflects a high reliance on short-term deposits for funding (more than 50 percent of liabilities) coupled with rapid growth in mortgage lending. The propensity to hold sight deposits has been exacerbated in recent years by low interest rates on term deposits in the wake of ECB quantitative easing and by the limited size of capital markets. The authorities have undertaken micro-prudential measures (such as a minimum liquidity coverage ratio), and are phasing in further measures (such as a net stable funding ratio) to address liquidity risks. 


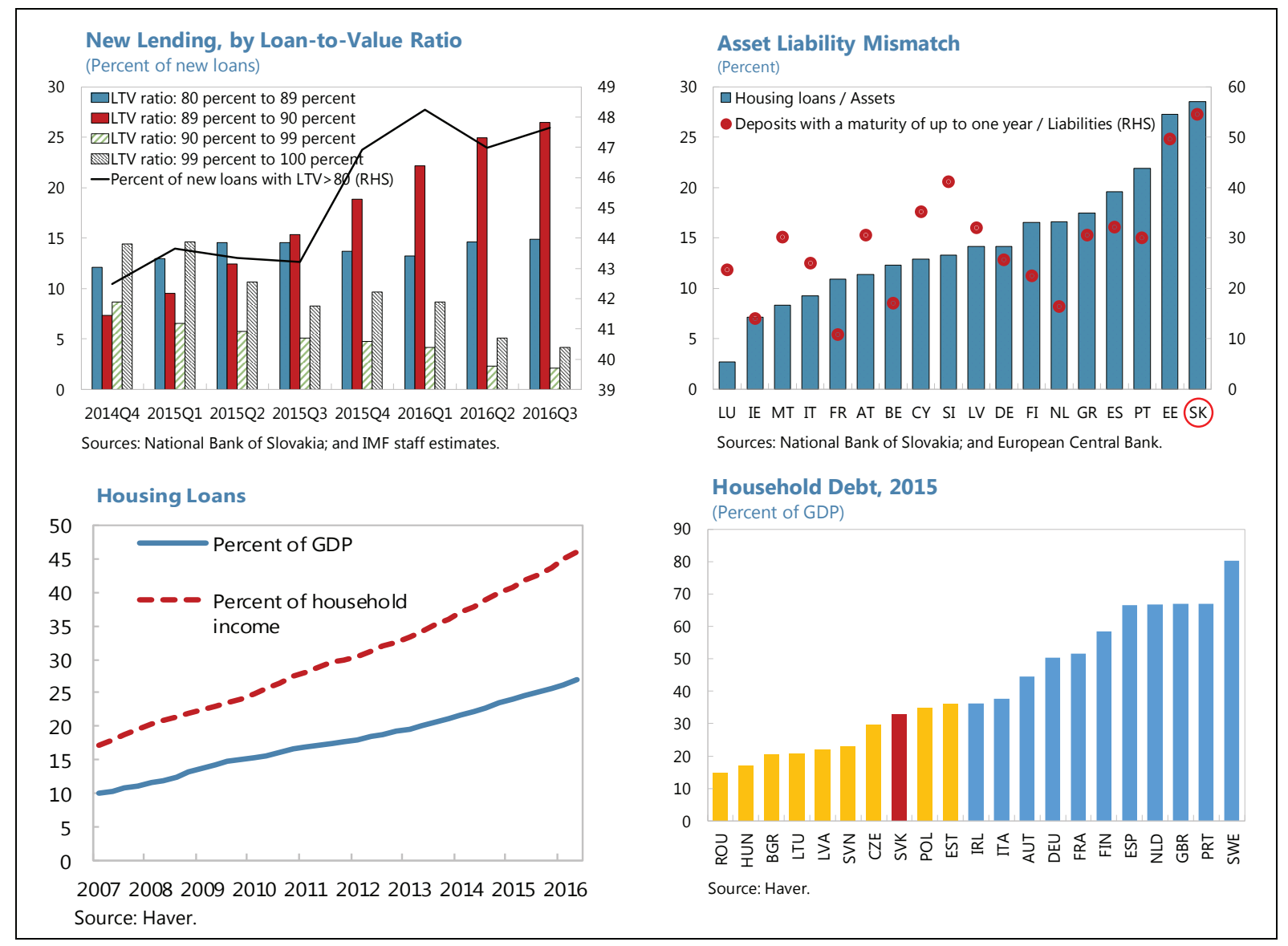

24. The authorities have stepped up macro-prudential measures since 2014 to preserve lending standards and increase buffers. Following the implementation of the Housing Loan Act (HLA) in March 2016, the NBS has a mandate to issue binding decrees imposing limits on debt service to income (DSTI) and LTV ratios which are set to further tighten in 2017. The amendment to the Consumer Credit Act that entered into force on January 1, 2017 introduces an obligation to verify the debt servicing capacity and income of consumer loan applicants, and a maturity limit for consumer loans as is the case for housing loans. Also, as of January 1, the O-SII buffer was increased to 2 percent and the systemic risk buffer to 1 percent for selected banks. In light of a strong positive credit-to-GDP gap relative to its long-term steady state and developments in the property market, the NBS decided to raise countercyclical buffer (CCB) from zero to 0.5 percent beginning August 1 , 2017. Banking sector legislation in Slovakia is fully harmonized, and supervision closely coordinated with the Single Supervisory Mechanism.

\section{Non-bank loans have remained stable accounting for roughly one-fifth of the volume}

of consumer loans. The NBS acquired responsibility for supervising non-banks in 2015, along with increased supervisory powers in the area of consumer financial protection. The introduction of a regulatory cap on interest rates has led to a sharp drop in annual percentage rates charged by non-banks, and has been partially responsible for a lengthening of the average terms and maturities of non-bank loans. While the interest rate cap has adversely affected non-bank profitability, it has also slowed the pace of new lending by non-banks and enhanced the stability of the sector. 
Harmonization of regulation and supervision for banks and non-banks will contribute to financial stability, and reduce risks in the non-bank sector.

\section{Discussion}

26. Staff discussed the effectiveness of macro-prudential measures. Measures implemented so far have had a limited impact on credit growth as banks rely on loan volume growth for profitability in a low-interest rate environment. With the current capital levels well above the minimum regulatory requirement, the increase in the CCB rate is likely to have limited impact on banks' lending behavior. While NBS's recent decision to expedite transposition of new EU directives would equalize the operating environment for bank and non-bank lenders, it may not materially slow rapid credit growth.

\section{Staff advised the authorities to consider the following additional measures:}

- Credit risk weights for real-estate loans, which are now standardized at 35 percent, should be increased for riskier subcomponents. In line with the latest Basel proposals, one option would be to impose higher risk weights on mortgage loans with LTV ratios over 80 percent or on mortgage loans for investment properties.

- Further lowering of the LTV ratio limit, which is among the highest in the EA, would allow Slovakia to curtail the sharp increase in recent quarters in new loans with excessively high LTVs.

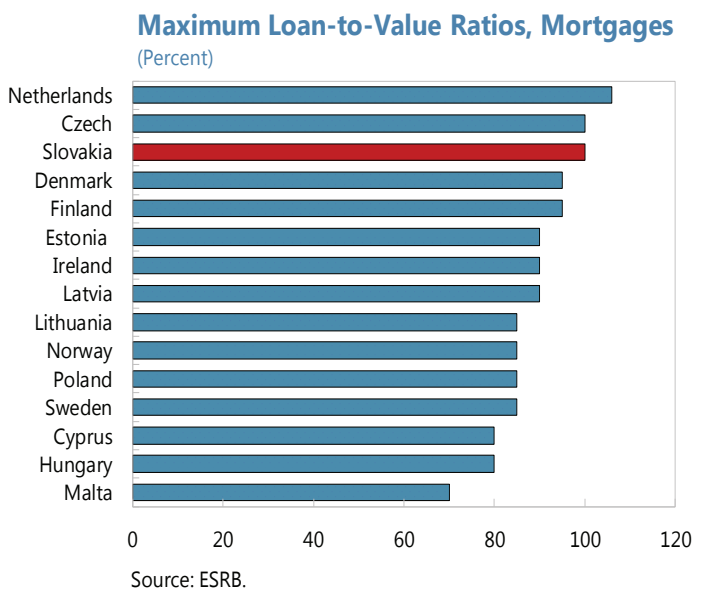

- Removing preferential treatment of capital gains from housing investment and linking realestate taxation to the market value of the property will curb demand for real estate and add to fiscal revenues. At the same time, lowering the bank tax to 0.1 percent as originally planned would help relieve pressures on bank's profitability.

\section{The authorities shared staff's views on credit risks that would stem from a possible} economic slowdown. The authorities underscored that, despite rapid growth in recent years, default rates in the housing portfolio of banks remained very low. In their view, the focus should be on the countercyclical buffer and tighter lending standards, rather than risk weights. While they recognized that the LTV ratio on new loans remains high, they also noted that obligatory amortization for all loans in Slovakia causes LTVs to drop rapidly over the lifespan of the loan. ${ }^{4}$ The authorities share staff's concern about rising default rates in the consumer credit market despite the favorable macroeconomic environment. The authorities believe that the deterioration in the credit

\footnotetext{
${ }^{4}$ In Slovakia, unlike in other EU countries there are no interest-only loans or loans with deferred payments which would have prevented such a rapid drop in LTV ratios.
} 
quality of consumer loans is mainly related to lending standards. They are in the process of drafting secondary legislation related to lending standards.

\section{Structural Reforms: Ensuring Steady Pace of Convergence and Reducing Regional Disparities}

\section{Background}

\section{Slowing productivity growth poses risks} to long-term convergence. Slovakia has achieved commendable success in increasing its share in the EU common market. Strong cost competitiveness and early links with German automotive supply chains contributed to this outcome. However, value added of exports and workers remain low. A shortage of skilled labor has started to dent productivity growth, which faces further headwinds from population aging (Annex I).
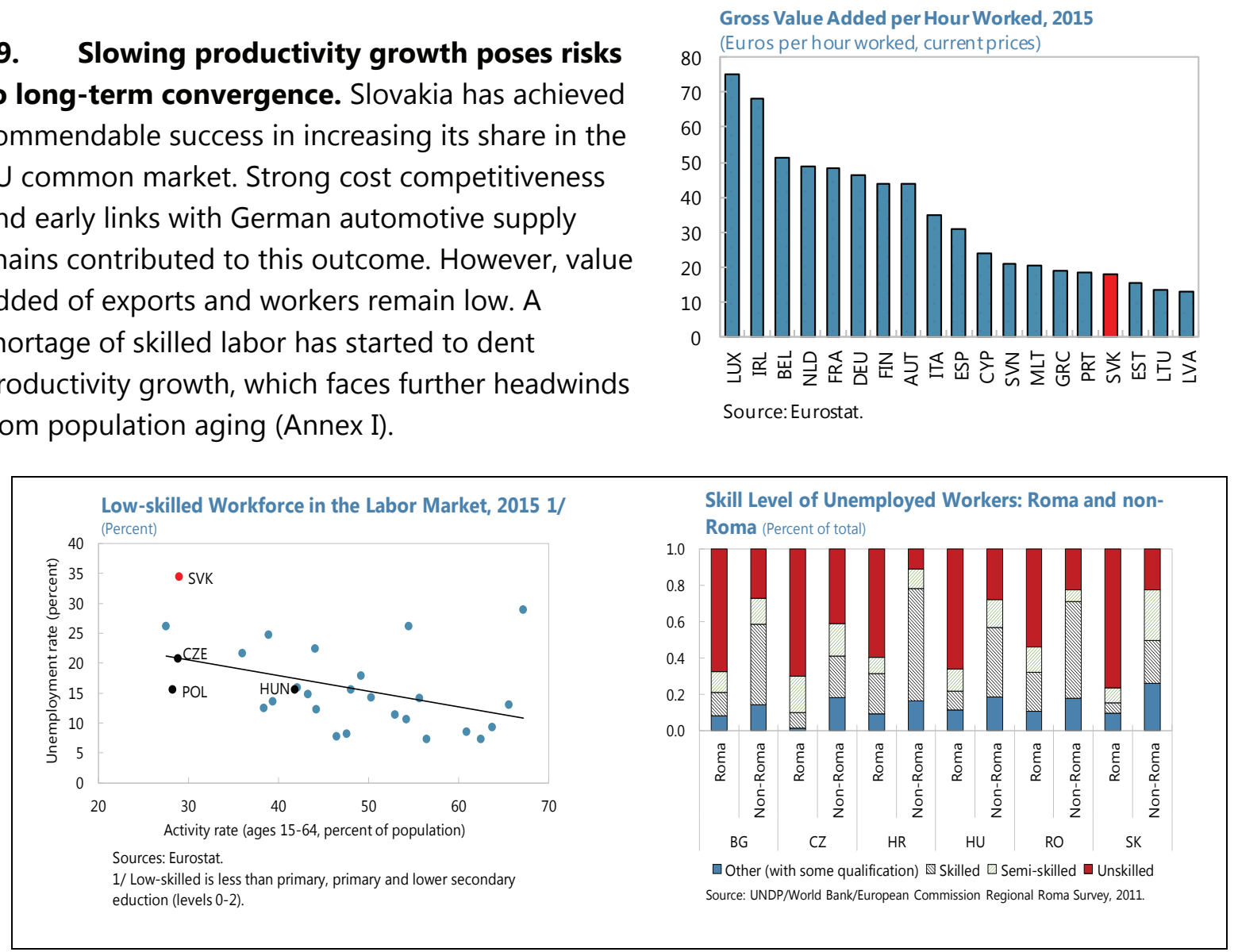

30. Regional disparities are perpetuated by inadequate infrastructure, but also divergence in skills. Education enrollment and completion rates, as well as PISA scores, are much lower in Eastern and Central Slovakia partly reflecting the significant concentration of the Roma population, whose enrollment rate is well below that for the rest of the population. Not surprisingly, these regions harbor a disproportionately high share of low-skilled workers, many of whom are either unemployed or inactive. In fact, Slovakia's low-skilled workers show one of the highest rates of unemployment and inactivity in the EU. The problem is particularly acute for the Roma population, who constitutes about 8 percent of total Slovak population. With 80 percent of unemployed Roma population lacking any type of formal workforce skills, the unemployment rate for this sub-group stands at a towering 70 percent. 
31. Meanwhile, domestic and foreign investors in the manufacturing sector suffer from shortages of skilled labor. A survey of foreign investors conducted by the German Chamber of Commerce active in sixteen Central and Eastern European countries ranks Slovakia in the bottom half in all areas of the labor market: qualification of staff, adequacy of higher education and vocational training, legal flexibility of employment and availability of skilled workers. Shortage of skilled labor is partially being met by foreign workers and domestic workers with lower skills, which is affecting productivity. Outmigration of Slovaks, primarily skilled workers, to other EU countries also contribute to this phenomenon.

32. Besides a shortage of skilled labor, businesses face other hurdles. Surveys conducted by international organizations indicate perceptions of corruption, and a lack of impartiality in the judiciary, which negatively affect Slovakia's business climate. ${ }^{5}$ Similarly, a survey conducted by the EU also highlights higher corruption and poorer quality of government relative to the average EU country. While these surveys are all subject to various shortcomings, they show weaknesses in similar areas.

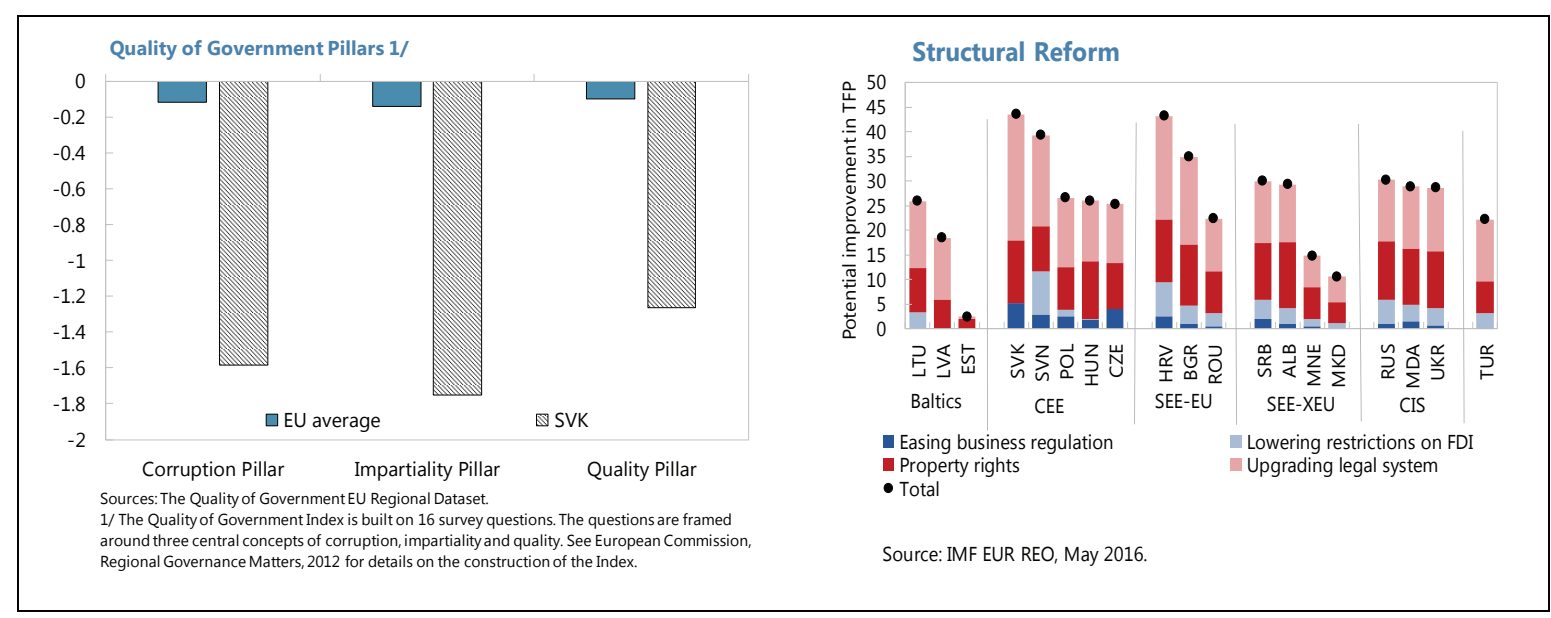

${ }^{5}$ See Transparency International Corruption Perceptions Index (2016), World Economic Forum Global Competitiveness Index (2016-17), and World Bank Doing Business Indicators (2017). 
33. Significant gains in productivity can be expected from addressing these weaknesses. A stochastic frontier analysis that estimates emerging European countries' distance from the productivity frontier and identifies factors behind country-specific gaps shows a significant technical efficiency gap for Slovakia relative to advanced Europe. Simple calculations suggest that closing reform gaps in business regulation, the legal system, and protection of property rights could reduce technical efficiency by about 40 percent in the long run. ${ }^{6}$ While these empirical estimates should be treated with caution and as indicative, reforms in these areas could counter a possible productivity slowdown caused by aging workforce.

\section{Discussion}

34. Staff stressed the importance of active labor market policies to address high regional unemployment. Slovakia's spending on ALMP is among the lowest in the EU. In the past, the programs focused on public works and various programs to target youth unemployment. Staff mentioned the importance of skills and on-the-job training to ensure ALMPs become a vehicle for lasting graduation to the job market rather than a vehicle for social assistance. The authorities highlighted recent changes to their ALMPs, noting their efforts to re-orient ALMPs to support the reintegration of the long-term unemployed and the Roma population into the labor market. In addition, they plan to complete the ongoing expenditure review of labor market policies in April 2017 and expect it to yield recommendations to improve the efficiency of ALMP spending.

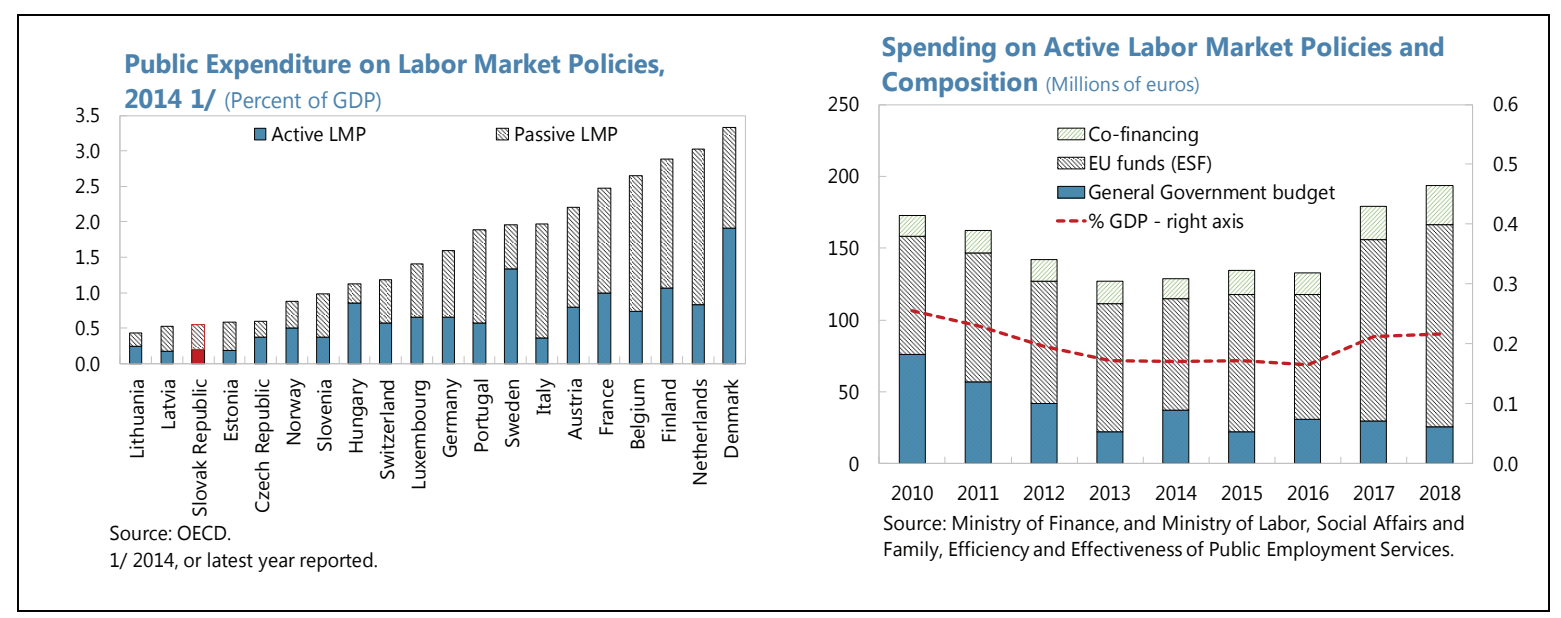

35. Staff welcomed authorities' efforts to address regional disparities. To accelerate development of lagging regions the government has passed the Law on Support of Lagging Regions (Act No. 336/2015 Coll.). Initially the support is provided to the 12 (out of 79) districts of Slovakia with the highest unemployment rates. The initiative, based on a bottom up approach, targets job creation in sectors in which lagging regions have a comparative advantage: family farming and viticulture combined with processing of agricultural products, agro-tourism and traditional crafts. This initiative also covers a significant part of the Roma community and aims to provide complex assistance to activate and bring low-skilled labor to the formal labor market. The

\footnotetext{
${ }^{6}$ See Central, Eastern, and South-Eastern Europe Regional Economic Issues, Spring 2016 for more details.
} 
program is financed from European structural investment funds, the government budget ( $€ 10$ million a year) and private funds.

\section{Addressing the shortage of skilled labor will require both short- and long-term} measures. Staff recommended that the authorities revise work permitting rules and enhance vocational education to address a growing labor skills mismatch. The authorities recognized that the lengthy period of time it takes to issue foreign worker permits, generally more than six months, is an obstacle to resolving the current labor skills gap. They also acknowledged that continued efforts to improve vocational and on-the-job training, which are somewhat limited, could play a greater role.

\section{Recent measures to improve judicial and business regulations are useful, but} implementation will be important. Staff welcomed steps to streamline local government, ease business registration through the creation of one-stop shops, and harmonize public procurement legislation with that of the EU. Staff also stressed the importance of ensuring transparency and competitiveness in the public procurement system. Moreover, staff argued that improving the efficiency, transparency, and independence of the judicial system and enforcing the ban on offering and accepting unethical advantages by government officials in the management of public property would help reduce the perception of corruption. Finally, mandatory disclosure rules for public companies, government contracts, and government officials should be extended to cover local government.

\section{STAFF APPRAISAL}

38. Slovakia continues to enjoy strong economic growth. Real incomes are now more than 70 percent of the EU average. Rising employment and real wages supported estimated GDP growth of 3.3 percent in 2016. Similar growth is forecast for 2017 due, in part, to a rebound in EU funds absorption. Planned investment in the automotive sector is projected to drive growth in the medium term.

39. Risks to the optimistic outlook are primarily external. The United Kingdom's planned exit from the European Union and elections in Europe's larger economies create some uncertainty about growth prospects in Slovakia's key trading partners. Continued rapid growth in credit to households, following several years of double-digit increases, is a potential domestic risk.

\section{An aging population and sharp regional disparities are key long-term challenges.}

Productivity growth has nearly halved since 2008. With its population aging the fastest in Europe, a further slowdown in productivity is likely unless countered by structural reforms. At the same time, the Bratislava region has captured the lion's share of Slovakia's past economic success.

Underdeveloped infrastructure, lower educational attainment, and limited labor mobility have held back the Eastern and Central regions.

41. The authorities' planned fiscal consolidation is appropriate and can create space for addressing regional inequities and future aging-related spending. It is important to identify clear measures to meet the balanced budget objective by 2019. On current policies, the fiscal deficit 
is likely to be 0.7 percent of GDP in 2019. To close the gap, the authorities should save in whole or in part expenditure reductions identified in current spending reviews, and increase VAT and corporate tax efficiency by implementing a compliance strategy that targets tax evaders. In addition, further fiscal space should be created by raising property and environmental tax collections to preserve public investment.

42. To safeguard the stability generated by the FRA, Slovakia's fiscal anchor, debt rules and brakes should not be modified to provide more favorable treatment of any specific type of investment. To strengthen cash management, modifications to allow for government cash balances to be netted out from gross debt can be considered when assessing performance relative to the debt ceiling: the current ceiling on gross debt discourages pre-financing efforts during periods of low interest rates even when these have no impact on net debt. However, the introduction of any escape clause for investment spending should be avoided to allow the budget process to remain a forum for assessing the relative merits of competing demands for government spending. Staff also recommends keeping the debt limits and brakes at their current levels.

\section{Unwavering implementation of approved pension reforms is imperative to help} contain age-related spending. The politically-costly and significant pension reforms undertaken in 2012, including indexing benefits to inflation, will pay off only if implemented in full. In addition, reopening Pillar II should be avoided. Other measures such as indexing accrued pension benefits to inflation or broadening the social contribution base would yield further savings. In the health sector, current efforts to centralize procurement and restructure the hospital network should be advanced.

44. Continued regulatory and supervisory vigilance would help preserve the stability and health of Slovakia's banking system. Slovakia's banks are profitable, well-capitalized, and possess healthy balance sheets. Looking ahead, profit pressures stem from tight interest margins and the burden of the special levy on bank profits. In addition, bank exposure to Slovakia's households, which are among the most indebted in central and eastern Europe, has grown rapidly. The authorities have made good pre-emptive use of micro- and macro-prudential measures such as introduction of tighter loan-to-value (LTV) ratios and introduction of a systemic risk buffer in 2017. However, further steps may be necessary to maintain credit quality in the current environment of high credit growth. Specifically, the authorities should consider imposing higher risk weights on riskier mortgage loans, lowering the maximum LTV ratio, and reducing the bank tax as originally planned.

45. To support productivity growth and sustain convergence, measures to improve labor market efficiency and the business environment are needed. The shift in active labor market policies (ALMP) toward activities that move the long-term unemployed into the labor market are welcome. Successful implementation of recommendations from the ongoing expenditure review of ALMP will be important to maximize benefits. In the near term, a review and possible relaxation of the process for granting work permits to foreign workers could help ease the growing skills mismatch. In the long run, revamping education policies to strengthen vocational training will be needed to ensure a better match of labor supply and demand. Beyond the labor market, tackling the widespread perception of corruption in Slovakia will require steps to improve judicial transparency 
and independence and the assiduous implementation of recent measures to curb unethical behavior in government.

\section{Implementing a comprehensive strategy to improve economic outcomes in} underdeveloped regions is also essential to boost growth and equity. Effective and timely absorption of EU funds can help address shortcomings. The focus needs to be on identifying priority infrastructure projects that facilitate further investment and labor mobility in under-developed regions, establishing clear selection criteria and following a competitive procurement process. The authorities' recent initiatives to create jobs in the lagging regions through an integrated approach of working with local businesses, communities and government is welcome.

47. It is proposed that the next Article IV consultation with the Slovak Republic take place on the standard 12-month cycle. 


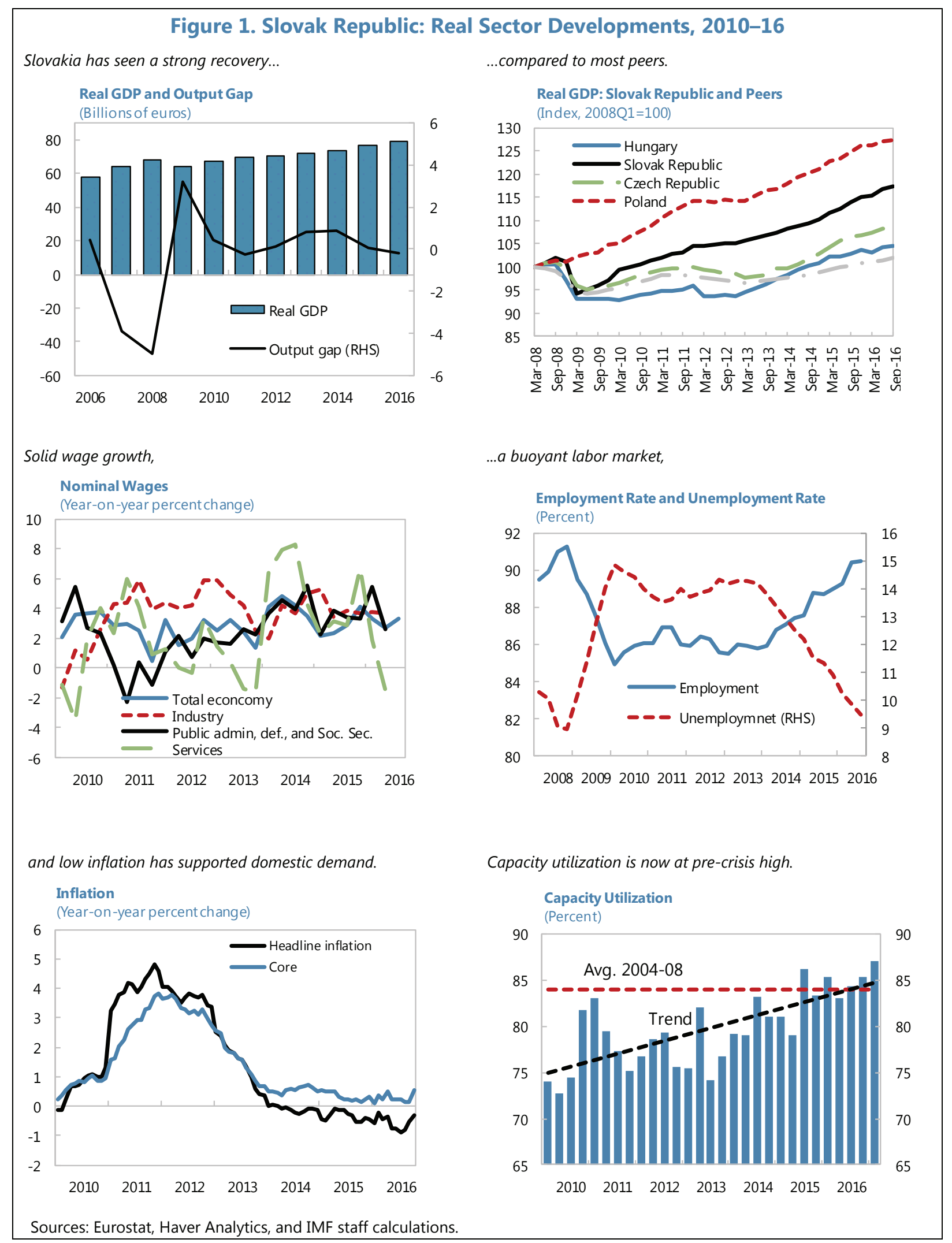


Figure 2. Slovak Republic: Labor Market Developments, 2010-16

Employment grew steadily since mid-2013...

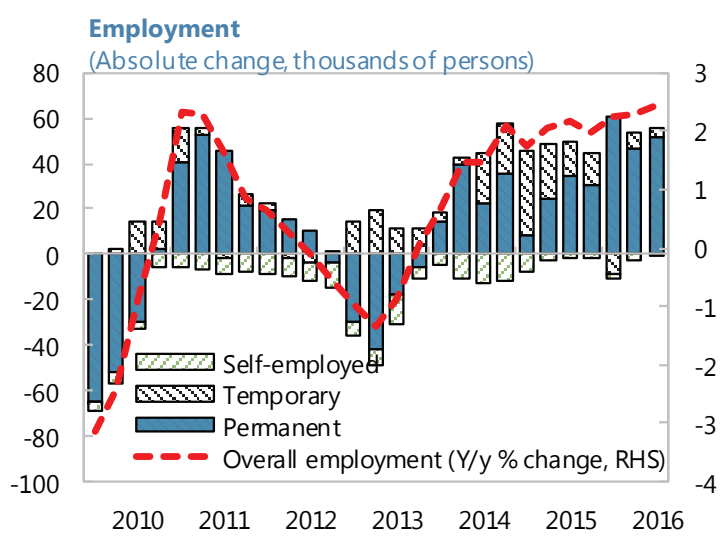

Youth unemployment has fallen from its high level...

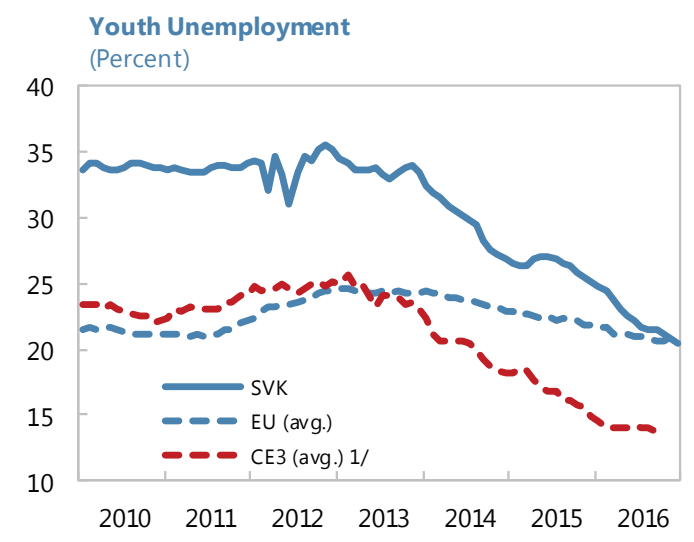

Although overall increase in the unit labor cost remains in line with peers...

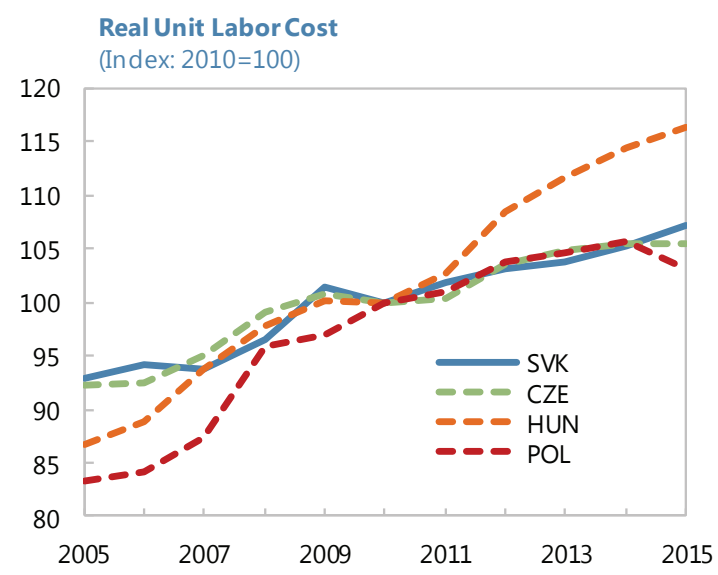

.... and unemployment rate is converging to the EU average.

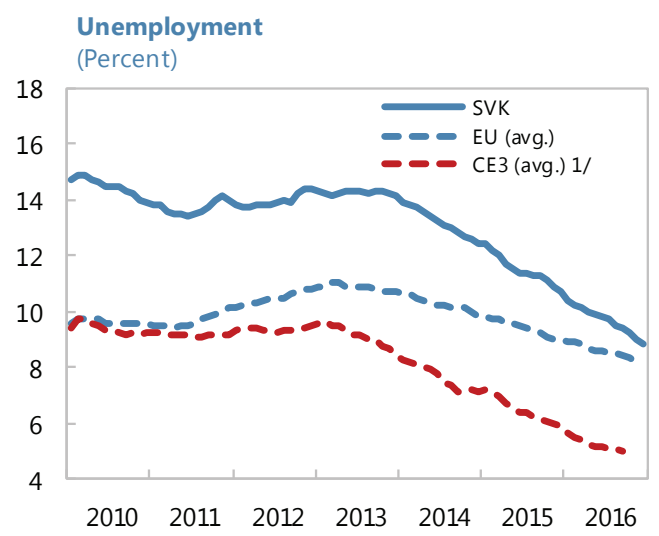

...real wage growth has recently surpassed productivity growth.

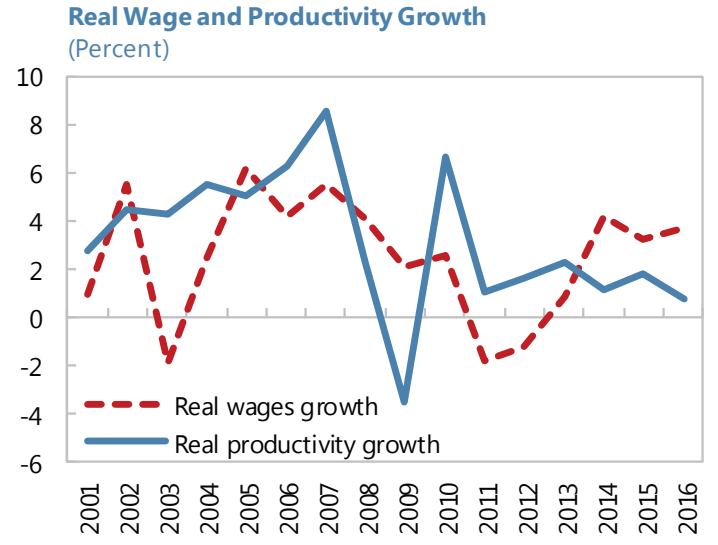

...and minimum wage levels are lower than in most European countries.

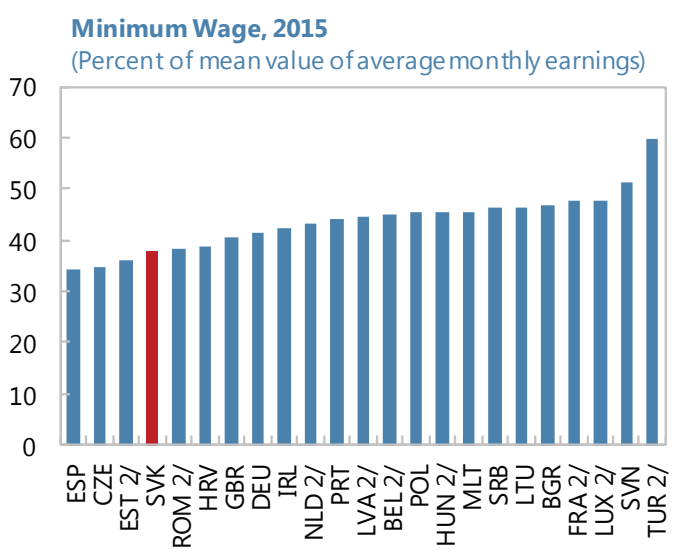

Sources: Eurostat; OECD; and IMF staff calculations.

1/ CE3 comprises Czech Republic, Hungary, and Poland. 2/ Reflects 2014 as data for 2015 are not available. 
Figure 3. Slovak Republic: Fiscal Developments, 2010-16

Revenues, excluding grants, continue to grow..

General Government Revenue (Percent of GDP)

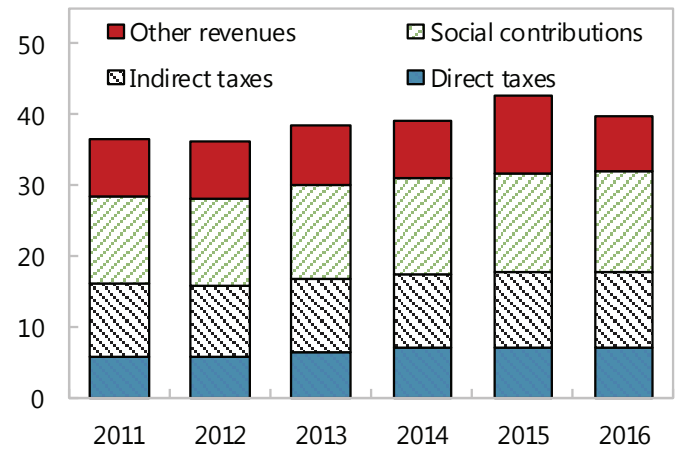

The fiscal stance has been improving...

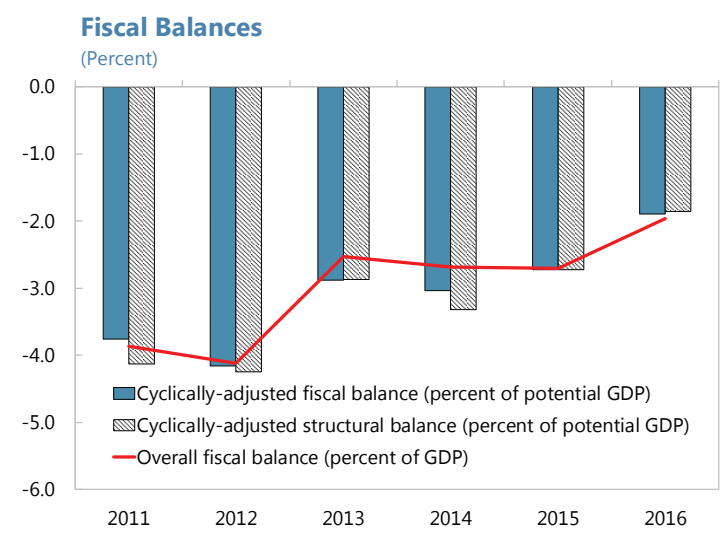

Yields remain at historically low levels...

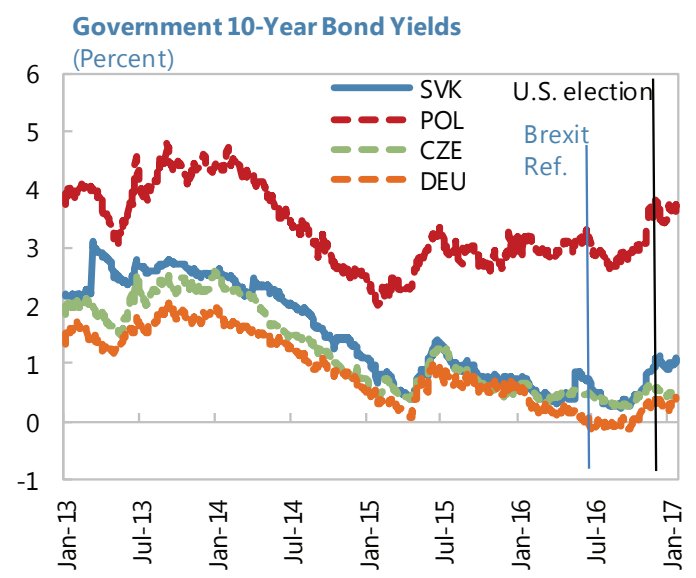

... and expenditures have begun to moderate.

General Government Expenditure

(Percent of GDP)

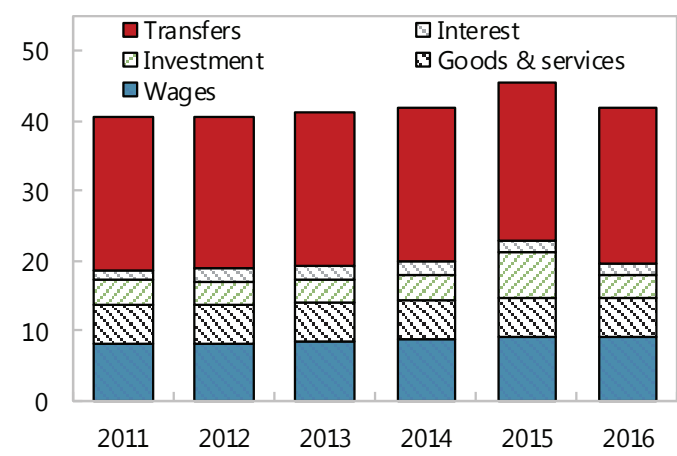

...and public debt declining.

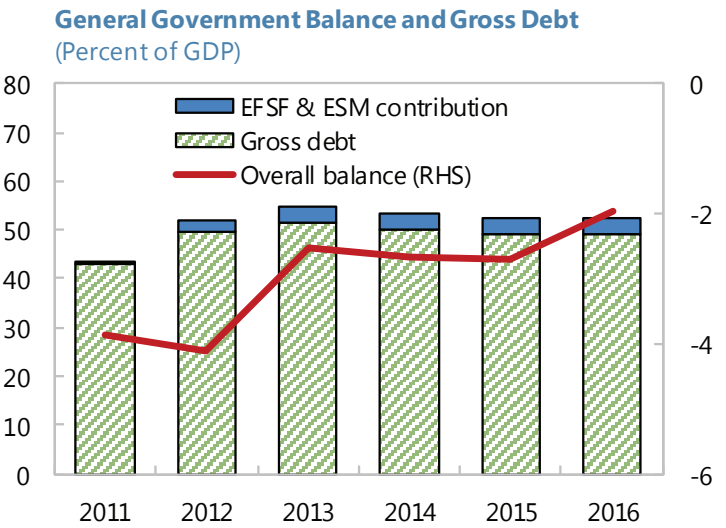

...as do sovereign spreads.

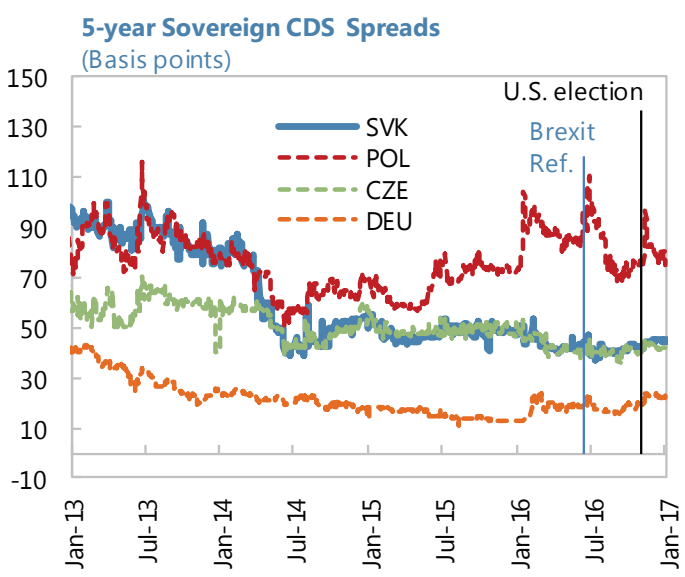

Sources: Bloomberg, Eurostat, National Authorities and IMF staff calculations. 


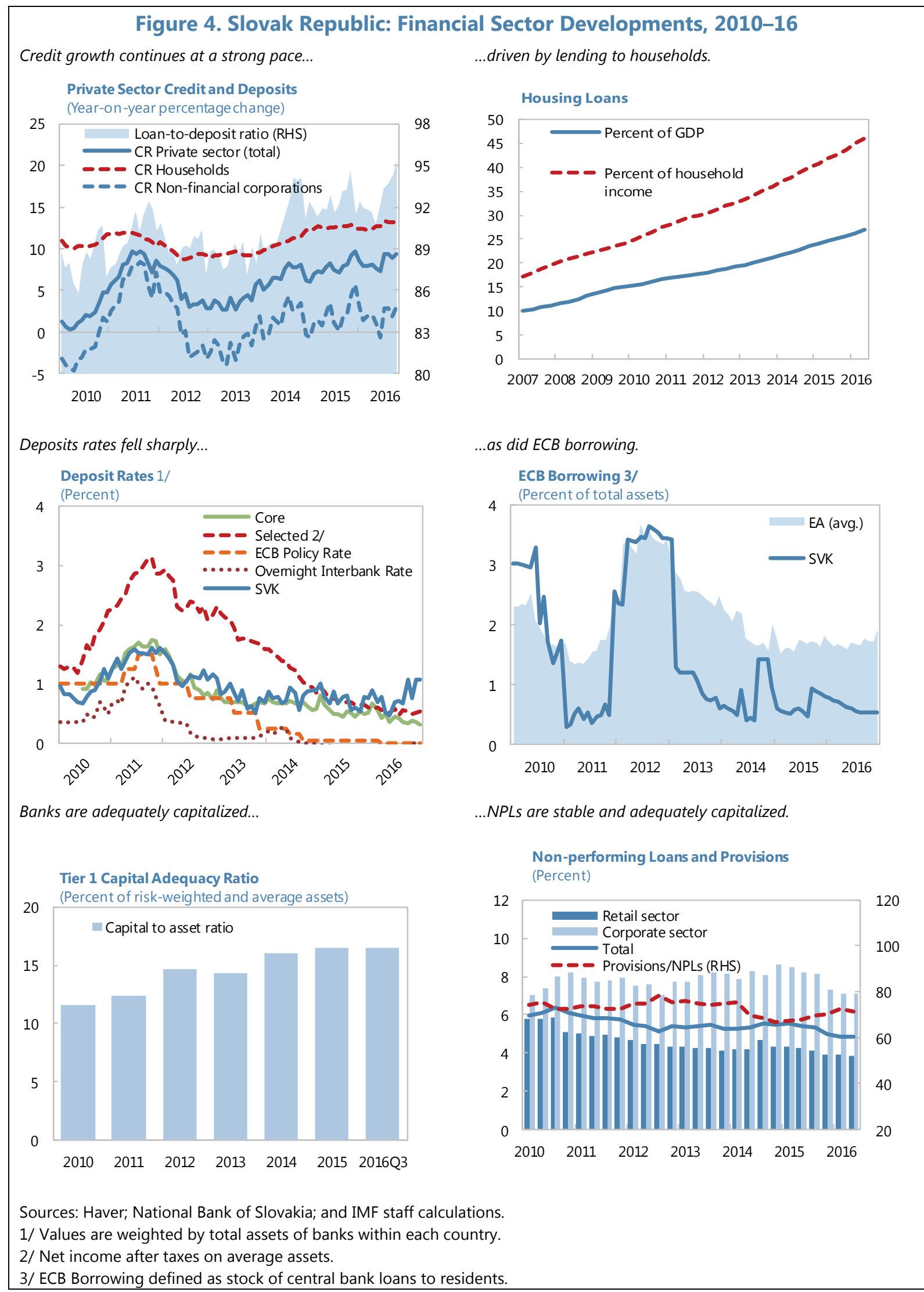


Figure 5. Slovak Republic: External Sector Developments, 2010-16

The current account is expected to be in surplus...

Current Account Balance

(Percent of GDP)

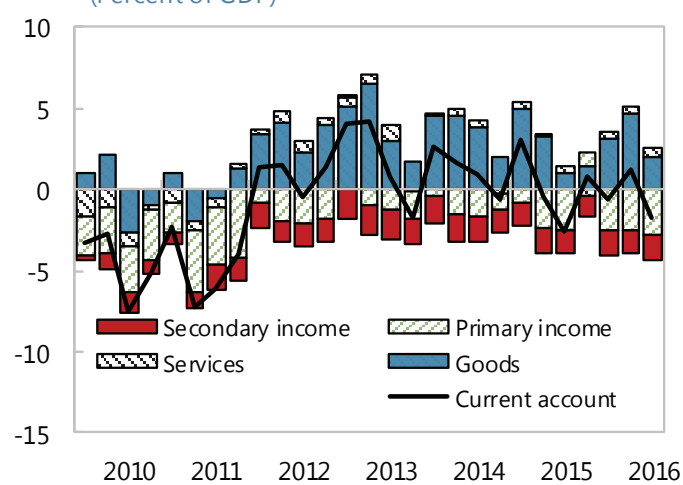

Real exports have almost doubled since 2009...

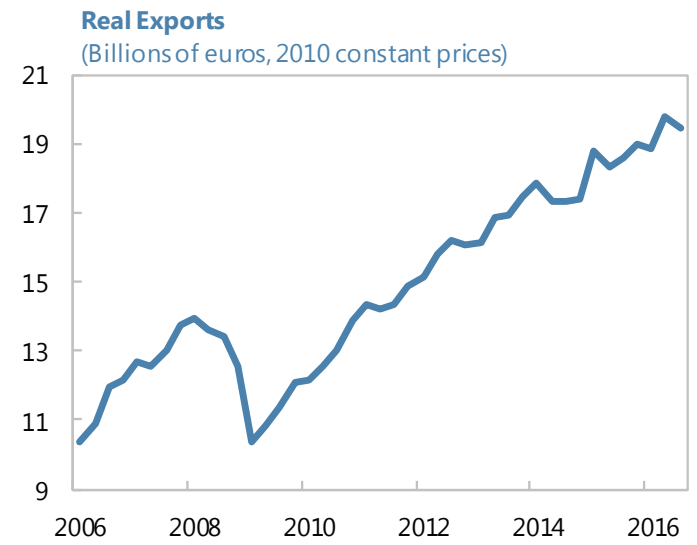

Net IIP is in line with peers...

Net International Investment Positions, 2016

(Percent of GDP)

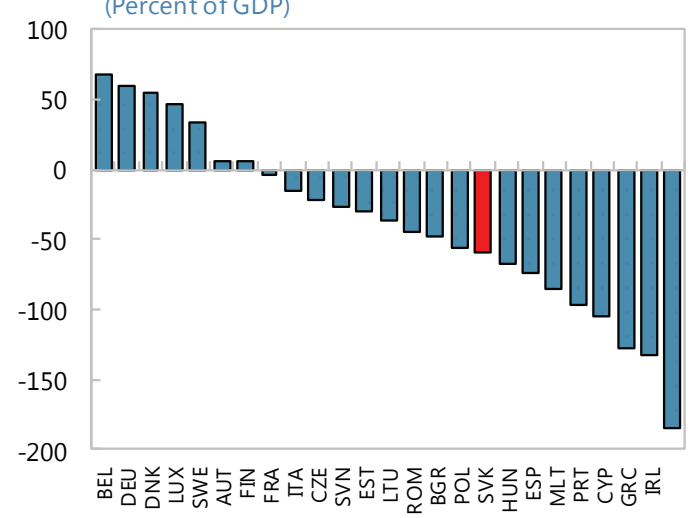

...reflecting improving trade balances.

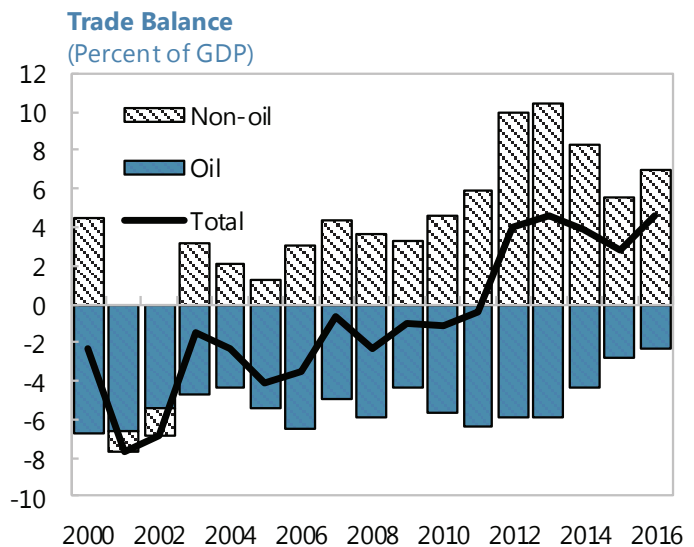

... resulting in increasing market shares in the $E U$.

Export Shares

(Percent of destination's total imports)

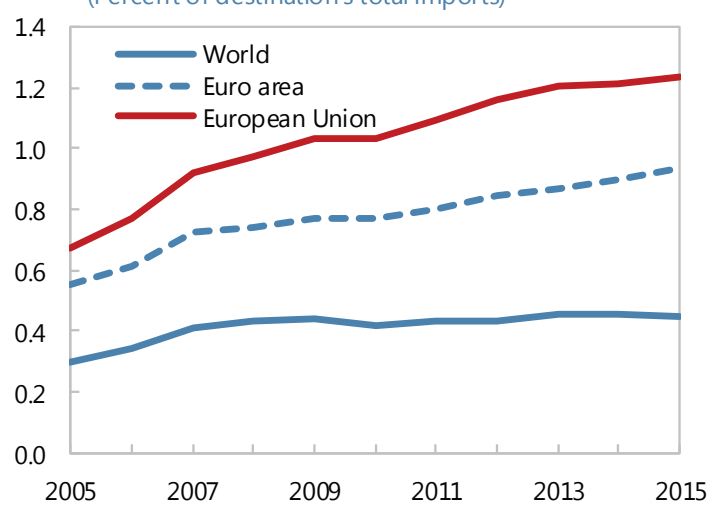

...and dominated by FDI.

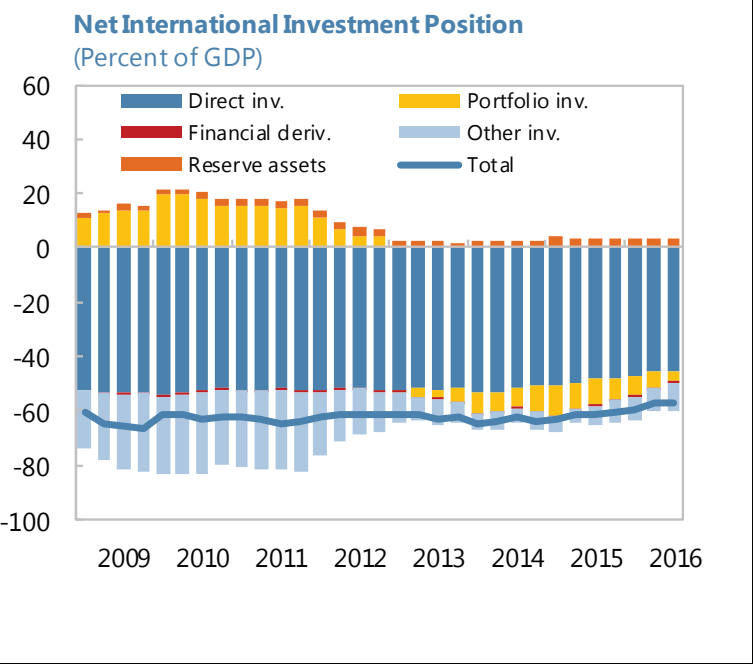




\begin{tabular}{|c|c|c|c|c|c|c|c|c|c|}
\hline & \multirow[b]{2}{*}{2014} & \multirow[b]{2}{*}{2015} & \multicolumn{7}{|c|}{ Projections } \\
\hline & & & 2016 & 2017 & 2018 & 2019 & 2020 & 2021 & 2022 \\
\hline & \multicolumn{9}{|c|}{ (Annual percentage change, constant prices, unless noted otherwise) } \\
\hline \multicolumn{10}{|l|}{ Output/Demand } \\
\hline Real GDP & 2.6 & 3.8 & 3.3 & 3.3 & 3.7 & 3.9 & 3.5 & 3.4 & 3.4 \\
\hline Domestic demand & 3.2 & 4.7 & 0.6 & 3.1 & 3.6 & 3.2 & 2.9 & 2.9 & 2.9 \\
\hline Public consumption & 5.3 & 5.4 & 3.0 & 1.9 & 3.0 & 3.8 & 2.7 & 1.8 & 1.8 \\
\hline Private consumption & 1.4 & 2.2 & 3.1 & 2.9 & 3.1 & 3.4 & 2.9 & 2.9 & 3.1 \\
\hline Gross fixed capital formation & 1.2 & 16.9 & -7.3 & 4.4 & 5.3 & 2.3 & 3.0 & 3.6 & 3.3 \\
\hline Exports of goods and services & 3.7 & 7.0 & 4.7 & 5.1 & 5.7 & 6.5 & 5.8 & 5.7 & 5.7 \\
\hline Imports of goods and services & 4.4 & 8.1 & 2.2 & 5.1 & 5.7 & 6.0 & 5.4 & 5.4 & 5.4 \\
\hline Output Gap & 0.9 & 0.0 & -0.2 & 0.0 & -0.1 & -0.3 & -0.2 & -0.1 & -0.2 \\
\hline \multicolumn{10}{|l|}{ Contribution to growth } \\
\hline Domestic demand & 3.0 & 4.6 & 0.9 & 3.0 & 3.6 & 3.3 & 2.9 & 2.9 & 2.9 \\
\hline Public consumption & 1.0 & 1.0 & 0.6 & 0.4 & 0.6 & 0.7 & 0.5 & 0.3 & 0.3 \\
\hline Private consumption & 0.8 & 1.2 & 1.7 & 1.6 & 1.7 & 1.9 & 1.6 & 1.6 & 1.7 \\
\hline Gross fixed capital formation & 0.2 & 3.4 & -1.7 & 0.9 & 1.1 & 0.5 & 0.6 & 0.7 & 0.7 \\
\hline Inventories & 1.1 & -1.1 & 0.3 & 0.1 & 0.2 & 0.2 & 0.2 & 0.2 & 0.2 \\
\hline Net exports & -0.5 & -0.7 & 2.4 & 0.3 & 0.1 & 0.6 & 0.6 & 0.5 & 0.5 \\
\hline \multicolumn{10}{|l|}{ Prices } \\
\hline Inflation (HICP) & -0.1 & -0.3 & -0.5 & 1.2 & 1.5 & 1.8 & 1.8 & 1.9 & 2.0 \\
\hline Inflation (HICP, end of period) & -0.1 & -0.5 & 0.2 & 1.5 & 1.6 & 1.8 & 2.0 & 2.0 & 2.0 \\
\hline GDP deflator & -0.2 & -0.2 & -0.8 & 0.3 & 1.5 & 1.8 & 1.8 & 1.9 & 2.0 \\
\hline \multicolumn{10}{|l|}{ Employment and wages } \\
\hline Employment & 1.4 & 2.0 & 2.5 & 3.0 & 1.1 & 1.1 & 1.1 & 1.1 & 1.1 \\
\hline Unemployment rate (Percent) & 13.2 & 11.5 & 8.7 & 7.8 & 7.3 & 7.1 & 6.3 & 5.4 & 5.4 \\
\hline \multirow[t]{2}{*}{ Nominal wages } & 4.1 & 2.9 & 3.2 & 3.5 & 4.1 & 4.3 & 4.0 & 3.9 & 3.2 \\
\hline & \multicolumn{9}{|c|}{ (Percent of GDP) } \\
\hline \multicolumn{10}{|l|}{ Public Finance, General Government } \\
\hline Revenue & 39.0 & 42.6 & 39.8 & 39.9 & 40.1 & 39.2 & 39.2 & 39.1 & 39.0 \\
\hline Expenditure & 41.7 & 45.3 & 41.8 & 41.7 & 41.2 & 39.8 & 39.8 & 39.7 & 39.5 \\
\hline Overall balance & -2.7 & -2.7 & -2.0 & -1.8 & -1.1 & -0.7 & -0.6 & -0.6 & -0.5 \\
\hline Primary balance & -0.8 & -1.2 & -0.5 & -0.4 & 0.2 & 0.7 & 0.8 & 0.9 & 1.0 \\
\hline Structural balance (Percent of potential GDP & -3.3 & -2.7 & -1.9 & -1.8 & -1.1 & -0.5 & -0.5 & -0.5 & -0.4 \\
\hline \multirow[t]{2}{*}{ General government debt } & 53.6 & 52.5 & 52.5 & 52.2 & 51.1 & 49.4 & 48.0 & 46.6 & 45.2 \\
\hline & \multicolumn{9}{|c|}{ (Percent) } \\
\hline \multicolumn{10}{|l|}{ Monetary and financial indicators } \\
\hline Credit to private sector (Growth rate) & 6.1 & 12.3 & 9.1 & 7.5 & 6.5 & 6.2 & 5.5 & 5.3 & 5.2 \\
\hline Lending rates $1 /$ & 4.0 & 3.1 & 2.6 & $\ldots$ & $\ldots$ & $\ldots$ & $\ldots$ & $\ldots$ & ... \\
\hline Deposit rates 2/ & 1.0 & 1.0 & 0.6 & $\ldots$ & $\ldots$ & $\ldots$ & $\ldots$ & $\ldots$ & ... \\
\hline \multirow[t]{2}{*}{ Government 10 -year bond yield } & 2.1 & 0.9 & 0.5 & 0.8 & 1.2 & 1.6 & 2.1 & 2.5 & 3.6 \\
\hline & \multicolumn{9}{|c|}{ (Percent of GDP) } \\
\hline \multicolumn{10}{|l|}{ Balance of payments } \\
\hline Trade balance (goods) & 3.8 & 2.7 & 4.3 & 3.6 & 3.6 & 4.1 & 4.5 & 4.8 & 5.1 \\
\hline Current account balance & 1.2 & 0.2 & 0.9 & 0.7 & 0.6 & 1.0 & 1.3 & 1.6 & 1.9 \\
\hline Gross external debt & 89.2 & 85.4 & 84.9 & 84.8 & 82.7 & 80.8 & 78.7 & 76.7 & 74.4 \\
\hline \multicolumn{10}{|l|}{ Saving and investment balance } \\
\hline Gross national savings & 22.9 & 23.4 & 22.6 & 23.0 & 23.7 & 24.2 & 24.9 & 25.6 & 26.2 \\
\hline Private sector & 22.6 & 20.4 & 21.6 & 21.8 & 22.3 & 22.7 & 23.4 & 24.3 & 25.0 \\
\hline Public sector & 0.2 & 3.0 & 1.1 & 1.2 & 1.5 & 1.5 & 1.4 & 1.3 & 1.3 \\
\hline Gross capital formation & 21.7 & 23.2 & 21.8 & 22.4 & 23.1 & 23.3 & 23.5 & 24.0 & 24.4 \\
\hline Memo item & & & & & & & & & \\
\hline Nominal GDP (Millions of euros) & 75,946 & 78,686 & 80,658 & 83,524 & 87,896 & 92,983 & 97,923 & 103,126 & 108,723 \\
\hline
\end{tabular}




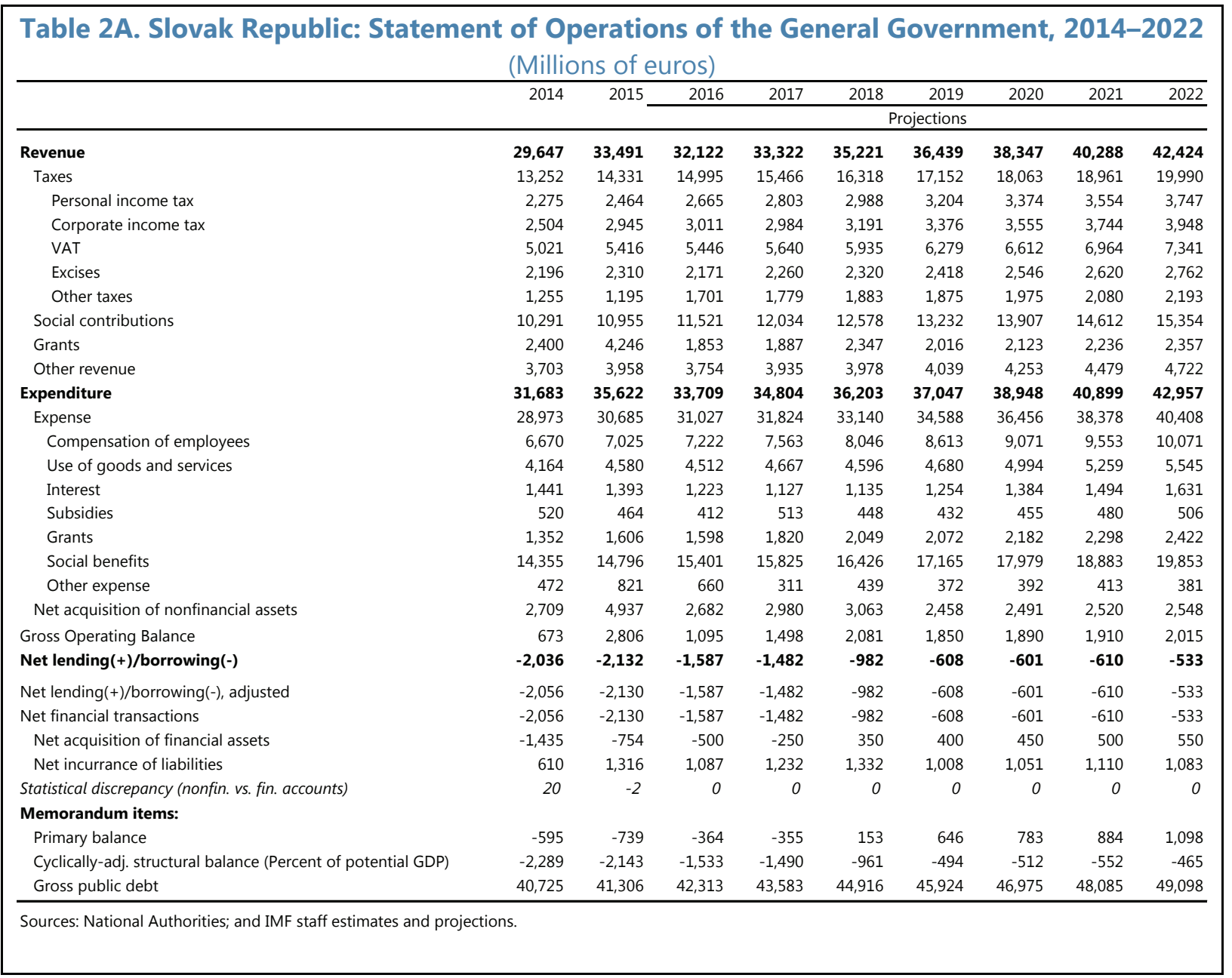




\begin{tabular}{|c|c|c|c|c|c|c|c|c|c|}
\hline & \multicolumn{9}{|c|}{ (Percent of GDP) } \\
\hline & 2014 & 2015 & 2016 & 2017 & 2018 & 2019 & 2020 & 2021 & 2022 \\
\hline & & & \multicolumn{7}{|c|}{ Projections } \\
\hline Revenue & 39.0 & 42.6 & 39.8 & 39.9 & 40.1 & 39.2 & 39.2 & 39.1 & 39.0 \\
\hline Taxes & 17.4 & 18.2 & 18.6 & 18.5 & 18.6 & 18.4 & 18.4 & 18.4 & 18.4 \\
\hline Personal income tax & 3.0 & 3.1 & 3.3 & 3.4 & 3.4 & 3.4 & 3.4 & 3.4 & 3.4 \\
\hline Corporate income tax & 3.3 & 3.7 & 3.7 & 3.6 & 3.6 & 3.6 & 3.6 & 3.6 & 3.6 \\
\hline VAT & 6.6 & 6.9 & 6.8 & 6.8 & 6.8 & 6.8 & 6.8 & 6.8 & 6.8 \\
\hline Excises & 2.9 & 2.9 & 2.7 & 2.7 & 2.6 & 2.6 & 2.6 & 2.5 & 2.5 \\
\hline Other taxes & 1.7 & 1.5 & 2.1 & 2.1 & 2.1 & 2.0 & 2.0 & 2.0 & 2.0 \\
\hline Social contributions & 13.6 & 13.9 & 14.3 & 14.4 & 14.3 & 14.2 & 14.2 & 14.2 & 14.1 \\
\hline Grants & 3.2 & 5.4 & 2.3 & 2.3 & 2.7 & 2.2 & 2.2 & 2.2 & 2.2 \\
\hline Other revenue & 4.9 & 5.0 & 4.7 & 4.7 & 4.5 & 4.3 & 4.3 & 4.3 & 4.3 \\
\hline Expenditure & 41.7 & 45.3 & 41.8 & 41.7 & 41.2 & 39.8 & 39.8 & 39.7 & 39.5 \\
\hline Expense & 38.1 & 39.0 & 38.5 & 38.1 & 37.7 & 37.2 & 37.2 & 37.2 & 37.2 \\
\hline Compensation of employees & 8.8 & 8.9 & 9.0 & 9.1 & 9.2 & 9.3 & 9.3 & 9.3 & 9.3 \\
\hline Use of goods and services & 5.5 & 5.8 & 5.6 & 5.6 & 5.2 & 5.0 & 5.1 & 5.1 & 5.1 \\
\hline Interest & 1.9 & 1.8 & 1.5 & 1.3 & 1.3 & 1.3 & 1.4 & 1.4 & 1.5 \\
\hline Subsidies & 0.7 & 0.6 & 0.5 & 0.6 & 0.5 & 0.5 & 0.5 & 0.5 & 0.5 \\
\hline Grants & 1.8 & 2.0 & 2.0 & 2.2 & 2.3 & 2.2 & 2.2 & 2.2 & 2.2 \\
\hline Social benefits & 18.9 & 18.8 & 19.1 & 18.9 & 18.7 & 18.5 & 18.4 & 18.3 & 18.3 \\
\hline Other expense & 0.6 & 1.0 & 0.8 & 0.4 & 0.5 & 0.4 & 0.4 & 0.4 & 0.4 \\
\hline Net acquisition of nonfinancial assets & 3.6 & 6.3 & 3.3 & 3.6 & 3.5 & 2.6 & 2.5 & 2.4 & 2.3 \\
\hline Gross Operating Balance & 0.9 & 3.6 & 1.4 & 1.8 & 2.4 & 2.0 & 1.9 & 1.9 & 1.9 \\
\hline Net lending(+)/borrowing(-) & -2.7 & -2.7 & -2.0 & -1.8 & -1.1 & -0.7 & -0.6 & -0.6 & -0.5 \\
\hline Net lending(+)/borrowing(-), adjusted & -2.7 & -2.7 & -2.0 & -1.8 & -1.1 & -0.7 & -0.6 & -0.6 & -0.5 \\
\hline Net financial transactions & -2.7 & -2.7 & -2.0 & -1.8 & -1.1 & -0.7 & -0.6 & -0.6 & -0.5 \\
\hline Net acquisition of financial assets & -1.9 & -1.0 & -0.6 & -0.3 & 0.4 & 0.4 & 0.5 & 0.5 & 0.5 \\
\hline Net incurrence of liabilities & 0.8 & 1.7 & 1.3 & 1.5 & 1.5 & 1.1 & 1.1 & 1.1 & 1.0 \\
\hline Statistical discrepancy (nonfin. vs. fin. accounts) & 0.0 & 0.0 & 0.0 & 0.0 & 0.0 & 0.0 & 0.0 & 0.0 & 0.0 \\
\hline \multicolumn{10}{|l|}{ Memorandum items: } \\
\hline Primary balance & -0.8 & -0.9 & -0.5 & -0.4 & 0.2 & 0.7 & 0.8 & 0.9 & 1.0 \\
\hline Cyclically-adj. structural balance (Percent of potential GDP) & -3.0 & -2.7 & -1.9 & -1.8 & -1.1 & -0.5 & -0.5 & -0.5 & -0.4 \\
\hline Gross public debt & 53.6 & 52.5 & 52.5 & 52.2 & 51.1 & 49.4 & 48.0 & 46.6 & 45.2 \\
\hline GDP at current market prices & 75,946 & 78,686 & 80,658 & 83,524 & 87,896 & 92,983 & 97,923 & 103,126 & 108,723 \\
\hline
\end{tabular}

Sources: National Authorities; and IMF staff estimates and projections. 


\begin{tabular}{|c|c|c|c|c|c|c|c|}
\hline & 2009 & 2010 & 2011 & 2012 & 2013 & 2014 & 2015 \\
\hline & \multicolumn{7}{|c|}{ (Billions of euros) } \\
\hline Net financial worth & $-11,600$ & $-18,327$ & $-21,935$ & $-23,211$ & $-25,357$ & $-27,110$ & $-28,629$ \\
\hline Financial assets & 15,562 & 13,662 & 13,312 & 19,146 & 19,967 & 18,835 & 18,007 \\
\hline Currency and deposits & 5,307 & 2,939 & 2,729 & 3,988 & 3,817 & 2,623 & 2,386 \\
\hline Debt securities & 366 & 209 & 209 & 206 & 21 & 50 & 20 \\
\hline Loans & 1,168 & 1,281 & 1,478 & 2,860 & 3,297 & 3,578 & 3,581 \\
\hline Equity and other investment fund shares & 6,054 & 6,103 & 5,079 & 8,428 & 8,546 & 8,392 & 8,007 \\
\hline Other accounts receivable & 2,668 & 3,129 & 3,818 & 3,664 & 4,286 & 4,192 & 4,014 \\
\hline Financial liabilities & 27,162 & 31,989 & 35,248 & 42,357 & 45,323 & 45,945 & 46,636 \\
\hline Currency and deposits & 84 & 71 & 101 & 93 & 110 & 105 & 421 \\
\hline Debt securities & 20,857 & 25,479 & 27,672 & 33,486 & 34,997 & 36,161 & 35,953 \\
\hline Loans & 2,759 & 2,835 & 3,713 & 5,041 & 6,155 & 5,452 & 5,706 \\
\hline \multirow[t]{2}{*}{ Other liabilities } & 3,463 & 3,603 & 3,763 & 3,737 & 4,061 & 4,227 & 4,556 \\
\hline & \multicolumn{7}{|c|}{ (Percent of GDP) } \\
\hline Net financial worth & -18.1 & -27.1 & -31.1 & -31.9 & -34.2 & -35.7 & -36.4 \\
\hline Financial assets & 24.3 & 20.2 & 18.8 & 26.3 & 26.9 & 24.8 & 22.9 \\
\hline Currency and deposits & 8.3 & 4.3 & 3.9 & 5.5 & 5.1 & 3.5 & 3.0 \\
\hline Securities other than shares & 0.6 & 0.3 & 0.3 & 0.3 & 0.0 & 0.1 & 0.0 \\
\hline Loans & 1.8 & 1.9 & 2.1 & 3.9 & 4.4 & 4.7 & 4.6 \\
\hline Shares and other equity & 9.5 & 9.0 & 7.2 & 11.6 & 11.5 & 11.0 & 10.2 \\
\hline Other accounts receivable & 4.2 & 4.6 & 5.4 & 5.0 & 5.8 & 5.5 & 5.1 \\
\hline Financial liabilities & 42.4 & 47.3 & 49.9 & 58.3 & 61.1 & 60.5 & 59.3 \\
\hline Currency and deposits & 0.1 & 0.1 & 0.1 & 0.1 & 0.1 & 0.1 & 0.5 \\
\hline Debt securities & 32.6 & 37.7 & 39.2 & 46.1 & 47.2 & 47.6 & 45.7 \\
\hline Loans & 4.3 & 4.2 & 5.3 & 6.9 & 8.3 & 7.2 & 7.3 \\
\hline Other liabilities & 5.4 & 5.3 & 5.3 & 5.1 & 5.5 & 5.6 & 5.8 \\
\hline \multicolumn{8}{|l|}{ Memorandum items: } \\
\hline Pulic debt & 22,980 & 27,504 & 30,480 & 37,926 & 40,600 & 40,725 & 41,306 \\
\hline Net lending/borrowing & $-4,909$ & $-4,888$ & $-2,727$ & $-2,991$ & $-1,876$ & $-2,036$ & $-2,132$ \\
\hline GDP & 64,023 & 67,577 & 70,627 & 72,704 & 74,170 & 75,946 & 78,686 \\
\hline
\end{tabular}




\begin{tabular}{|c|c|c|c|c|c|c|c|c|c|}
\hline & \multirow[b]{2}{*}{2014} & \multirow[b]{2}{*}{$2015^{-}$} & \multicolumn{7}{|c|}{ Projections } \\
\hline & & & 2016 & 2017 & 2018 & 2019 & 2020 & 2021 & 2022 \\
\hline & \multicolumn{9}{|c|}{ (Millions of euros) } \\
\hline Current account & 904 & 168 & 716 & 546 & 533 & 888 & 1,319 & 1,692 & 2,020 \\
\hline Trade balance (goods) & 2,859 & 2,115 & 3,506 & 3,004 & 3,193 & 3,798 & 4,380 & 4,951 & 5,511 \\
\hline Exports, f.o.b. & 62,581 & 66,089 & 68,220 & 75,350 & 80,713 & 86,313 & 91,599 & 97,963 & 104,735 \\
\hline Imports, f.o.b. & 59,722 & 63,974 & 64,715 & 72,345 & 77,520 & 82,515 & 87,219 & 93,011 & 99,224 \\
\hline Services balance & 109 & 95 & 241 & 169 & 184 & 240 & 293 & 343 & 392 \\
\hline Receipts & 6,821 & 7,239 & 7,467 & 8,248 & 8,840 & 9,454 & 10,033 & 10,730 & 11,472 \\
\hline Payments & 6,713 & 7,144 & 7,226 & 8,078 & 8,656 & 9,214 & 9,740 & 10,386 & 11,080 \\
\hline Primary income balance & -869 & -927 & $-1,739$ & $-1,472$ & $-1,624$ & $-1,859$ & $-1,985$ & $-2,151$ & $-2,344$ \\
\hline Credit & 3,699 & 3,808 & 3,106 & 3,544 & 3,602 & 3,575 & 3,662 & 3,735 & 3,790 \\
\hline Debit & 4,569 & 4,735 & 4,845 & 5,016 & 5,226 & 5,434 & 5,647 & 5,886 & 6,133 \\
\hline Secondary income balance & $-1,194$ & $-1,115$ & $-1,292$ & $-1,156$ & $-1,220$ & $-1,291$ & $-1,369$ & $-1,451$ & $-1,539$ \\
\hline Credit & 486 & 551 & 408 & 574 & 595 & 614 & 636 & 659 & 684 \\
\hline Debit & 1,680 & 1,666 & 1,700 & 1,730 & 1,815 & 1,904 & 2,005 & 2,110 & 2,223 \\
\hline Capital account & 730 & 2,790 & 1,295 & 1,402 & 1,422 & 1,476 & 1,647 & 1,415 & 1,436 \\
\hline Financial Account & -361 & 849 & 2,011 & 1,948 & 1,955 & 2,364 & 2,966 & 3,107 & 3,456 \\
\hline Direct investment, net & 418 & 11 & -483 & $-2,196$ & $-2,681$ & $-1,802$ & $-1,815$ & $-1,773$ & $-1,728$ \\
\hline Assets & 94 & 1,028 & 2,092 & 835 & 879 & 744 & 783 & 825 & 870 \\
\hline Liabilities & -324 & 1,017 & 2,575 & 3,031 & 3,560 & 2,546 & 2,598 & 2,598 & 2,598 \\
\hline Portfolio investment, net & $-1,794$ & 1,856 & 2,000 & 2,071 & 1,973 & 2,124 & 1,982 & 1,844 & 1,817 \\
\hline Assets & 1,484 & -529 & 3,000 & 3,125 & 3,062 & 2,960 & 2,885 & 2,793 & 2,693 \\
\hline Liabilities & 3,278 & $-2,385$ & 1,000 & 1,054 & 1,089 & 836 & 903 & 949 & 876 \\
\hline Other investment, net & 241 & $-1,492$ & 111 & 1,972 & 2,640 & 2,018 & 2,773 & 3,011 & 3,341 \\
\hline Assets & 2,950 & $-1,600$ & 380 & 3,257 & 3,428 & 3,626 & 3,819 & 4,022 & 4,240 \\
\hline Liabilities & 2,709 & -109 & 269 & 1,286 & 788 & 1,609 & 1,046 & 1,011 & 900 \\
\hline Financial derivatives, net & 320 & 231 & 383 & 101 & 23 & 24 & 25 & 25 & 26 \\
\hline Reserve assets $1 /$ & 454 & 242 & 0 & 0 & 0 & 0 & 0 & 0 & 0 \\
\hline Errors and omissions & $-1,995$ & $-2,109$ & 0 & 0 & 0 & 0 & 0 & 0 & 0 \\
\hline Net International Investment Position & $-52,174$ & $-54,316$ & $-52,305$ & $-50,357$ & $-48,402$ & $-46,038$ & $-43,073$ & $-39,966$ & $-36,510$ \\
\hline External Debt & 67,776 & 67,225 & 68,494 & 70,834 & 72,711 & 75,156 & 77,105 & 79,065 & 80,840 \\
\hline Current account & 1.2 & 0.2 & 0.9 & 0.7 & 0.6 & 1.0 & 1.3 & 1.6 & 1.9 \\
\hline Trade balance (goods) & 3.8 & 2.7 & 4.3 & 3.6 & 3.6 & 4.1 & 4.5 & 4.8 & 5.1 \\
\hline Exports, f.o.b. & 82.4 & 84.0 & 84.6 & 90.2 & 91.8 & 92.8 & 93.5 & 95.0 & 96.3 \\
\hline Imports, f.o.b. & 78.6 & 81.3 & 80.2 & 86.6 & 88.2 & 88.7 & 89.1 & 90.2 & 91.3 \\
\hline Services balance & 0.1 & 0.1 & 0.3 & 0.2 & 0.2 & 0.3 & 0.3 & 0.3 & 0.4 \\
\hline Receipts & 9.0 & 9.2 & 9.3 & 9.9 & 10.1 & 10.2 & 10.2 & 10.4 & 10.6 \\
\hline Payments & 8.8 & 9.1 & 9.0 & 9.7 & 9.8 & 9.9 & 9.9 & 10.1 & 10.2 \\
\hline Primary income balance & -1.1 & -1.2 & -2.2 & -1.8 & -1.8 & -2.0 & -2.0 & -2.1 & -2.2 \\
\hline Credit & 4.9 & 4.8 & 3.9 & 4.2 & 4.1 & 3.8 & 3.7 & 3.6 & 3.5 \\
\hline Debit & 6.0 & 6.0 & 6.0 & 6.0 & 5.9 & 5.8 & 5.8 & 5.7 & 5.6 \\
\hline Secondary income balance & -1.6 & -1.4 & -1.6 & -1.4 & -1.4 & -1.4 & -1.4 & -1.4 & -1.4 \\
\hline Credit & 0.6 & 0.7 & 0.5 & 0.7 & 0.7 & 0.7 & 0.6 & 0.6 & 0.6 \\
\hline Debit & 2.2 & 2.1 & 2.1 & 2.1 & 2.1 & 2.0 & 2.0 & 2.0 & 2.0 \\
\hline Capital account & 1.0 & 3.5 & 1.6 & 1.7 & 1.6 & 1.6 & 1.7 & 1.4 & 1.3 \\
\hline Financial Account & -0.5 & 1.1 & 2.5 & 2.3 & 2.2 & 2.5 & 3.0 & 3.0 & 3.2 \\
\hline Direct investment, net & 0.6 & 0.0 & -0.6 & -2.6 & -3.1 & -1.9 & -1.9 & -1.7 & -1.6 \\
\hline Portfolio investment, net & -2.4 & 2.4 & 2.5 & 2.5 & 2.2 & 2.3 & 2.0 & 1.8 & 1.7 \\
\hline Other investment, net & 0.3 & -1.9 & 0.1 & 2.4 & 3.0 & 2.2 & 2.8 & 2.9 & 3.1 \\
\hline Financial derivatives, net & 0.4 & 0.3 & 0.5 & 0.1 & 0.0 & 0.0 & 0.0 & 0.0 & 0.0 \\
\hline Reserve assets & 0.6 & 0.3 & 0.0 & 0.0 & 0.0 & 0.0 & 0.0 & 0.0 & 0.0 \\
\hline Errors and omissions & -2.6 & -2.7 & 0.0 & 0.0 & 0.0 & 0.0 & 0.0 & 0.0 & 0.0 \\
\hline Net International Investment Position & -68.7 & -69.0 & -64.8 & -60.3 & -55.1 & -49.5 & -44.0 & -38.8 & -33.6 \\
\hline External Debt & 89.2 & 85.4 & 84.9 & 84.8 & 82.7 & 80.8 & 78.7 & 76.7 & 74.4 \\
\hline
\end{tabular}


Table 5. Slovak Republic: Financial Soundness Indicators for the Banking Sector, 2010-2016Q3 (Percent, unless otherwise indicated)

\begin{tabular}{|c|c|c|c|c|c|c|c|}
\hline & 2010 & 2011 & 2012 & 2013 & 2014 & 2015 & 2016Q3 \\
\hline \multicolumn{8}{|l|}{ Capital adequacy } \\
\hline Regulatory capital to risk-weighted assets & 12.7 & 13.4 & 15.7 & 16.5 & 17.3 & 17.8 & 17.7 \\
\hline Regulatory Tier 1 capital to risk-weighted assets & 11.6 & 12.4 & 14.7 & 14.4 & 16.0 & 16.5 & 16.5 \\
\hline Capital to assets & 9.7 & 10.8 & 11.7 & 12.1 & 11.9 & 11.1 & 10.7 \\
\hline \multicolumn{8}{|l|}{ Asset quality } \\
\hline Nonperforming loans to gross loans & 5.8 & 5.6 & 5.2 & 5.1 & 5.3 & 4.9 & 4.7 \\
\hline Nonperforming loans net of provisions to capital & 16.7 & 15.5 & 13.3 & 13.1 & 15.8 & 13.9 & 13.4 \\
\hline \multicolumn{8}{|l|}{ Earnings and Profitability } \\
\hline Return on assets (after tax) & 1.2 & 0.7 & 1.0 & 1.3 & 1.2 & 1.3 & 1.4 \\
\hline Return on equity (after tax) & 12.6 & 6.9 & 9.1 & 10.7 & 10.4 & 11.2 & 13.4 \\
\hline Interest margin to gross income & 75.9 & 73.9 & 84.1 & 78.1 & 80.4 & 76.9 & 74.5 \\
\hline Noninterest expenses to gross income & 57.5 & 52.5 & 64.3 & 59.1 & 60.0 & 58.5 & 59.5 \\
\hline \multicolumn{8}{|l|}{ Liquidity } \\
\hline Customer deposits to total (noninterbank) loans & 116.6 & 109.4 & 114.2 & 113.0 & 110.3 & 111.0 & 107.4 \\
\hline Liquid assets to total assets & 40.9 & 37.4 & 38.3 & 36.2 & 34.1 & 34.2 & 32.2 \\
\hline Liquid assets to short-term liabilities & 56.5 & 52.9 & 55.9 & 49.1 & 46.0 & 45.9 & 42.6 \\
\hline \multicolumn{8}{|l|}{ Sectoral distribution of loans to total loans } \\
\hline Residents & 93.6 & 93.6 & 92.4 & 91.6 & 91.0 & 93.6 & 93.5 \\
\hline Deposit-takers & 0.0 & 0.0 & 0.0 & 0.0 & 0.0 & 0.1 & 0.2 \\
\hline Central bank & 0.0 & 0.0 & 0.0 & 0.0 & 0.0 & 0.0 & 0.0 \\
\hline Other financial corporations & 2.9 & 2.8 & 2.3 & 2.3 & 1.9 & 1.9 & 1.8 \\
\hline General government & 3.2 & 2.9 & 2.6 & 2.3 & 2.3 & 2.2 & 1.9 \\
\hline Nonfinancial corporations & 42.2 & 41.6 & 38.9 & 36.2 & 33.4 & 33.7 & 32.4 \\
\hline Other domestic sectors & 45.3 & 46.2 & 48.6 & 50.7 & 53.5 & 55.7 & 57.2 \\
\hline Nonresidents & 6.4 & 6.4 & 7.6 & 8.4 & 9.0 & 6.4 & 6.5 \\
\hline \multicolumn{8}{|l|}{ Other indicators } \\
\hline Nonfinancial corporation debt (in percent of GDP) & 81.7 & 83.9 & 81.4 & 85.6 & 85.5 & 87.3 & 86.9 \\
\hline Households debt (in percent of GDP) & 27.8 & 29.2 & 32.0 & 34.4 & 36.8 & 39.0 & 40.8 \\
\hline Households debt (in percent of disposable income) & 44.2 & 47.4 & 52.8 & 56.3 & 60.4 & 63.9 & 68.8 \\
\hline Gross asset position in financial derivatives to capital & 7.6 & 8.0 & 5.5 & 3.7 & 5.4 & 4.3 & 4.4 \\
\hline Gross liability position in financial derivatives to capital & 9.4 & 9.1 & 6.7 & 4.8 & 6.6 & 5.5 & 5.6 \\
\hline Trading income to total income & 2.9 & -4.1 & 1.4 & 3.5 & 3.9 & 5.1 & 8.5 \\
\hline Personnel expenses to noninterest expenses & 38.6 & 40.1 & 39.9 & 39.7 & 39.4 & 40.5 & 42.5 \\
\hline Spread between reference lending and deposit rates (basis points) & 395.0 & 376.5 & 359.0 & 379.3 & 369.4 & 343.4 & 306.0 \\
\hline Foreign currency-denominated loans to total loans & 1.5 & 1.6 & 1.5 & 1.1 & 1.9 & 1.8 & 2.0 \\
\hline Foreign currency-denominated liabilities to total liabilities & 3.2 & 4.1 & 3.6 & 3.9 & 4.2 & 3.8 & 3.6 \\
\hline Net open position in equities to capital & 9.6 & 9.1 & 8.3 & 14.4 & 12.6 & 12.6 & 12.4 \\
\hline Net open position in foreign exchange to capital & -1.2 & -1.7 & 0.1 & 2.2 & 3.7 & 2.5 & 2.3 \\
\hline
\end{tabular}




\section{Annex I. Labor Productivity: Developments and Outlook ${ }^{1}$}

\section{Slovakia has experienced a drastic slowdown in productivity growth since the global financial}

crisis. Slowing productivity growth has been a common experience across the region reflecting both lower TFP growth and, in most cases, reduced capital deepening, which has lowered potential growth. In case of Slovakia, estimates show that average annual labor productivity growth has declined from 4.3 percent during 2000-08 to around 1.8 percent during 2008-15 largely due to lower TFP growth. TFP growth declined relatively less in Slovakia than in central European peers. Lower growth in capital stock as well as poor investment performance since the crisis also contributed to the productivity slowdown.

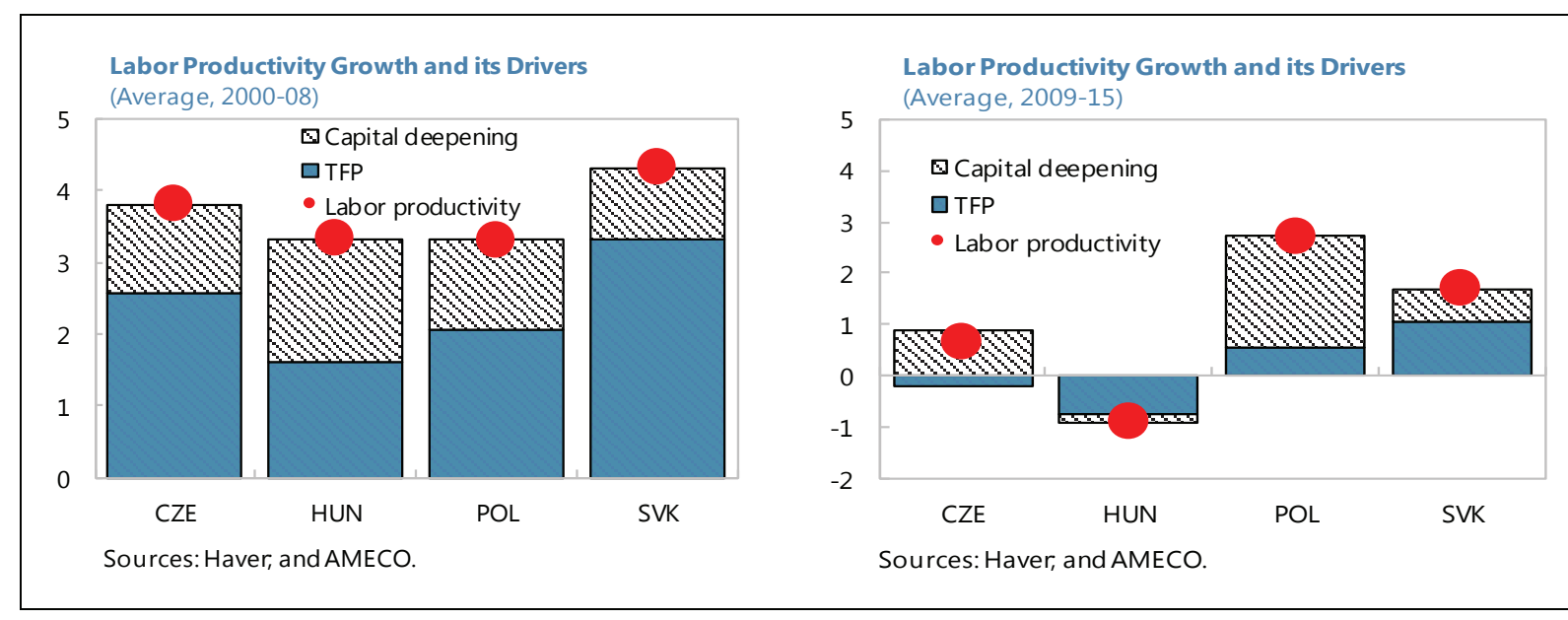

The aging workforce is estimated to have contributed to the productivity slowdown. Slovakia has experienced both population and workforce aging in the last decade. A declining fertility rate and longer life expectancy have driven down the natural change of the population, which, with little offset from immigration, has been stagnant, or even dipping into negative territory in recent years, resulting in a high and increasing old age dependency ratio. During this same period, Slovakia's workforce has aged with the share of older workers (55+) more than tripling to over 15 percent. The aging of workers is estimated to have caused a loss of annual TFP growth of about 0.3 percent during 1996-2007.

A further productivity slowdown can be expected if the current trend continues. The old age dependency ratio is expected to rise, much like elsewhere in Europe. The composition of the workforce will continue to shift towards older workers with workers aged 55+ constituting about a fifth of the workforce by 2034. With fewer available workers in the economy, the increasing old age dependency ratio will inevitably increase the burden falling on each worker. Population aging may also alter the structure of industries, shifting from manufacturing to the less productive services sector. While experience enhances productivity, old age workers are also disproportionately affected

\footnotetext{
${ }^{1}$ Prepared by Xiaobo Shao and Dustin Smith based on Economic Growth in Slovakia: Past Successes and Future Challenges, European Commission Economic Brief 008 (March 2015) and IMF Euro Area Policy Selected Issues (2016).
} 
by the depreciation of knowledge and are typically less able to accommodate innovative ideas, presumably because proximity to retirement reduces the incentive to invest in human capital.

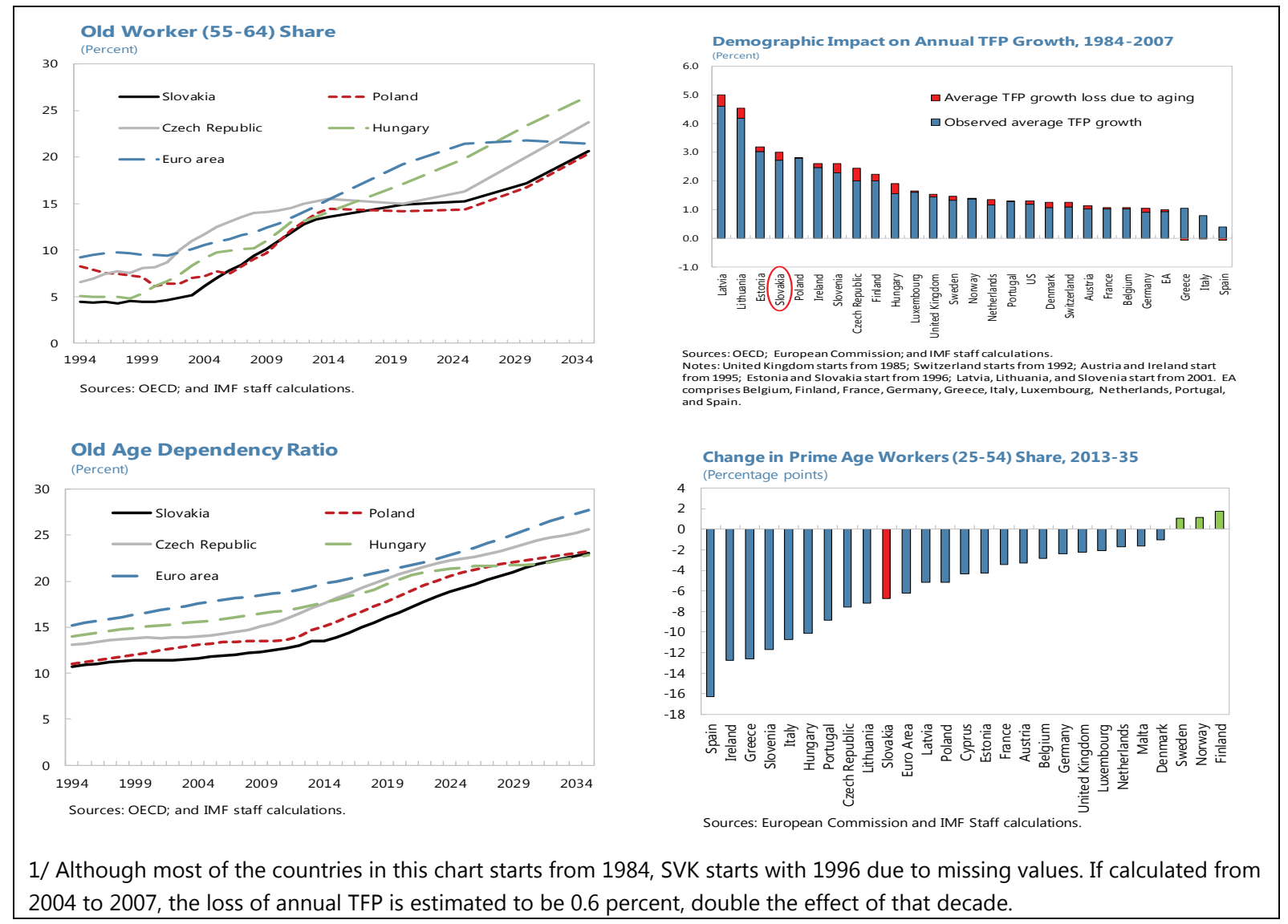

\section{Estimates show further TFP loss in the next two}

decades. Aiyar et al (2016) used standard panel techniques and an augmented Cobb-Douglas production function with human capital to estimate the effect of aging and its channels. Based on a model covering the major EU28 countries, the econometric results showed that an increase of the share of older workers (measured by the workers aged $55+$ to total workforce) is associated with an economically and statistically significant reduction in the growth rate of labor productivity, mostly coming from the adverse

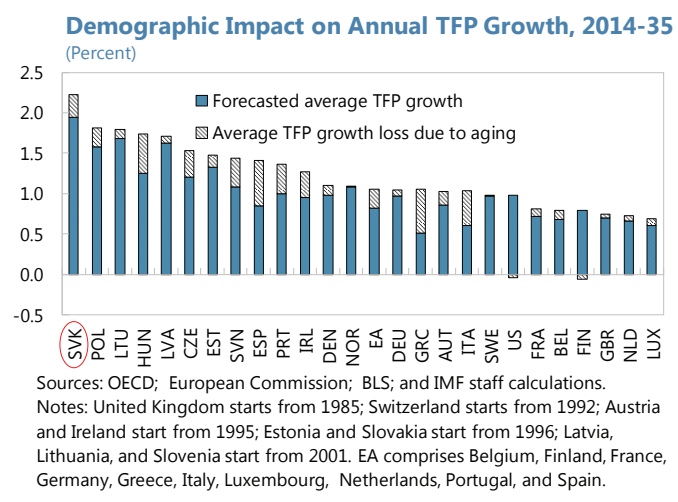
effect on TFP growth. Using point estimates from this study, estimates show workforce aging has decreased TFP growth by 0.3 percentage points each year between 1996-2007. The EC's 2015 Aging Report predicts a decline in the labor force participation rate over the next two decades, which, combined with the OECD's forecasts of population change by age group, could reduce the primeage (25-54) workers' share in the workforce, shaving off another 0.3 percent off TFP growth every year. 


\section{Annex II. Assessment of External Stability, Competitiveness and Vulnerabilities ${ }^{1}$}

\section{Slovakia's external position is broadly consistent with medium-term fundamentals and desirable policy settings.}

The current account-based assessment shows that the external position is stronger than justified by fundamentals. A policy gap of 0.6 percent suggests that Slovakia's financial, fiscal and external policies are appropriate. The current account gap from the EBA-Lite CA model (2.9 percent) indicates that Slovakia's external position is stronger than explained by fundamentals. The methodology points to a current account norm of negative 2 percent, whereas the actual current account is broadly in balance. This methodology implies a moderate REER undervaluation of negative 4.9 .

$\begin{array}{lc}\text { Slovakia: Estimated Current Account Gap and Real Exchange Rate Misalignment } \\ \text { EBA-lite CA model } \\ \text { CA-Actual } & -0.90 \% \\ \text { CA-Norm } & -2.00 \% \\ \text { CA-Gap } & 2.90 \% \\ \text { Real Exchange Rate Gap } & -4.90 \% \\ \text { CA-Fitted } & -1.30 \% \\ \text { Policy gap } & 0.70 \% \\ \text { EBA-lite REER model } & \\ \text { In(REER)-Actual } & 4.59 \\ \text { In(REER)-Norm } & 4.45 \\ \text { REER-Gap } & 15 \% \\ \text { In(REER)-Fitted } & 4.46 \\ \text { Policy gap } & 0.01\end{array}$

On the contrary, the REER EBA-lite approach points to a large overvaluation of $\mathbf{1 4}$ percent. Given that the estimated overvaluation in this approach is mostly driven by large residuals, staff relies on the CA approach for assessment of the external position. The REER index methodology also has limitations when applied to countries with large structural changes, such as the adoption of the Euro in 2009 in the case of Slovakia. Furthermore, the fitted REER series for Slovakia starts only in 1999 (due to unavailability of the real interest rate end-of period before this date), making it more difficult to capture long run trends. In staff's opinion, the extremely high appreciation implied by the REER model is also in contrast with the strong export performance as shown by rising market share and investor interest and the stable REER-CPI since 2009. Overall, staff assesses the real exchange rate to be broadly around its equilibrium value.

\footnotetext{
${ }^{1}$ Prepared by Francesca Caselli.
} 


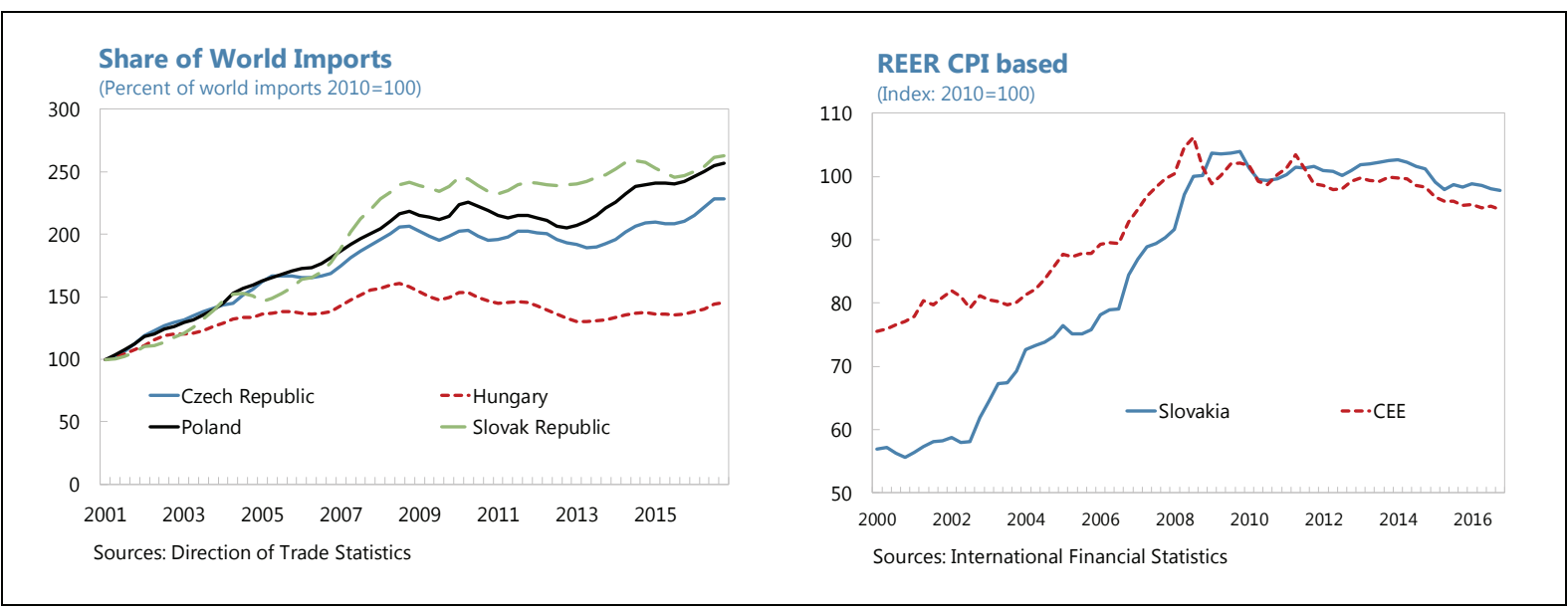

The level of the current account does not raise major competitiveness concerns, but there are vulnerabilities from a very concentrated export base. Since 2012, large surpluses in the goods balance have been almost offset by significant deficits in the primary and secondary incomes. The high negative primary income balance is driven by direct investment income, mainly in the form of dividends and reinvested earnings. Permanently high errors and omissions, possibly reflecting an overstatement of export prices due to branding, and frequent data revisions somewhat complicates a clear understanding of current account developments. However, a very concentrated export structure, in terms of product and market, poses risks from global slowdown. More than half of Slovakia's exports are concentrated in two sectors, transportation and mechanical and electrical products. In general, product concentration as measured by Herfindahl-Hirschman index at the SITC product level 3 digits, is higher than that of most other central European peers. Much of export growth has been driven by higher exports of existing products to existing markets, rather than introducing new products or entering new markets.

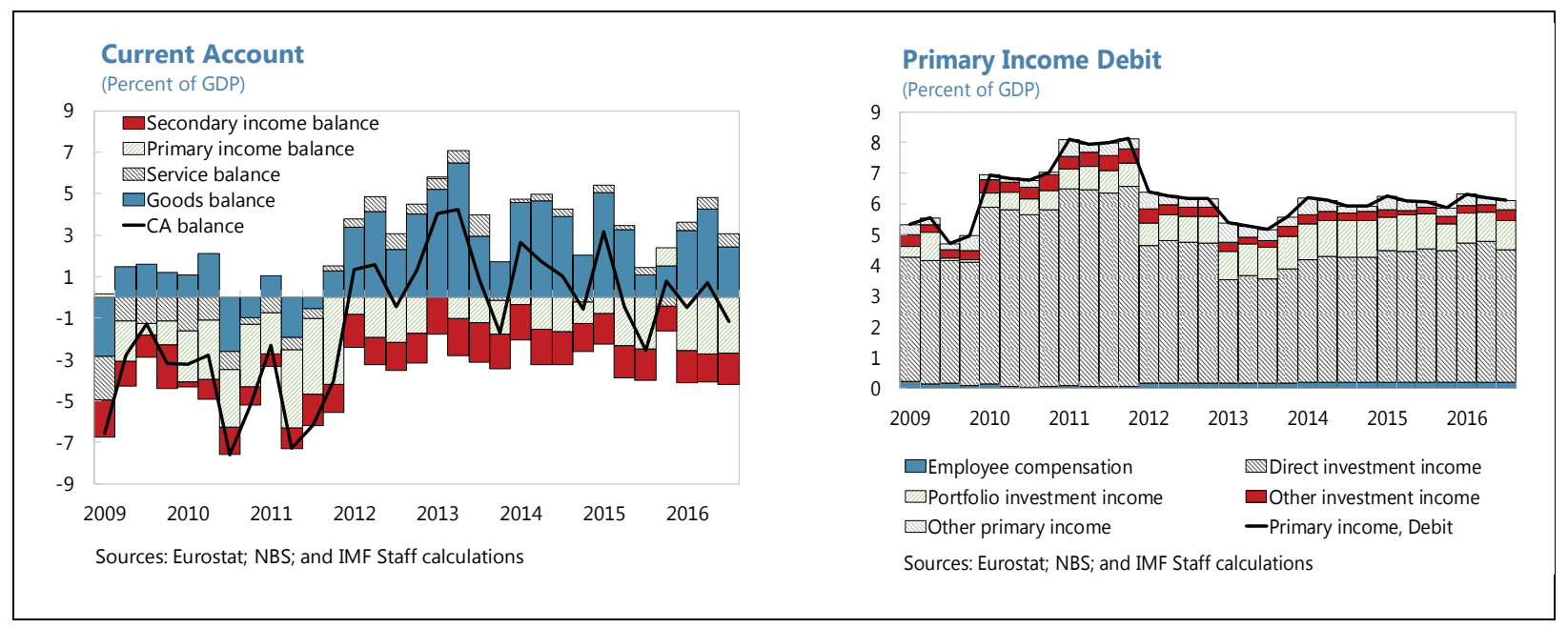




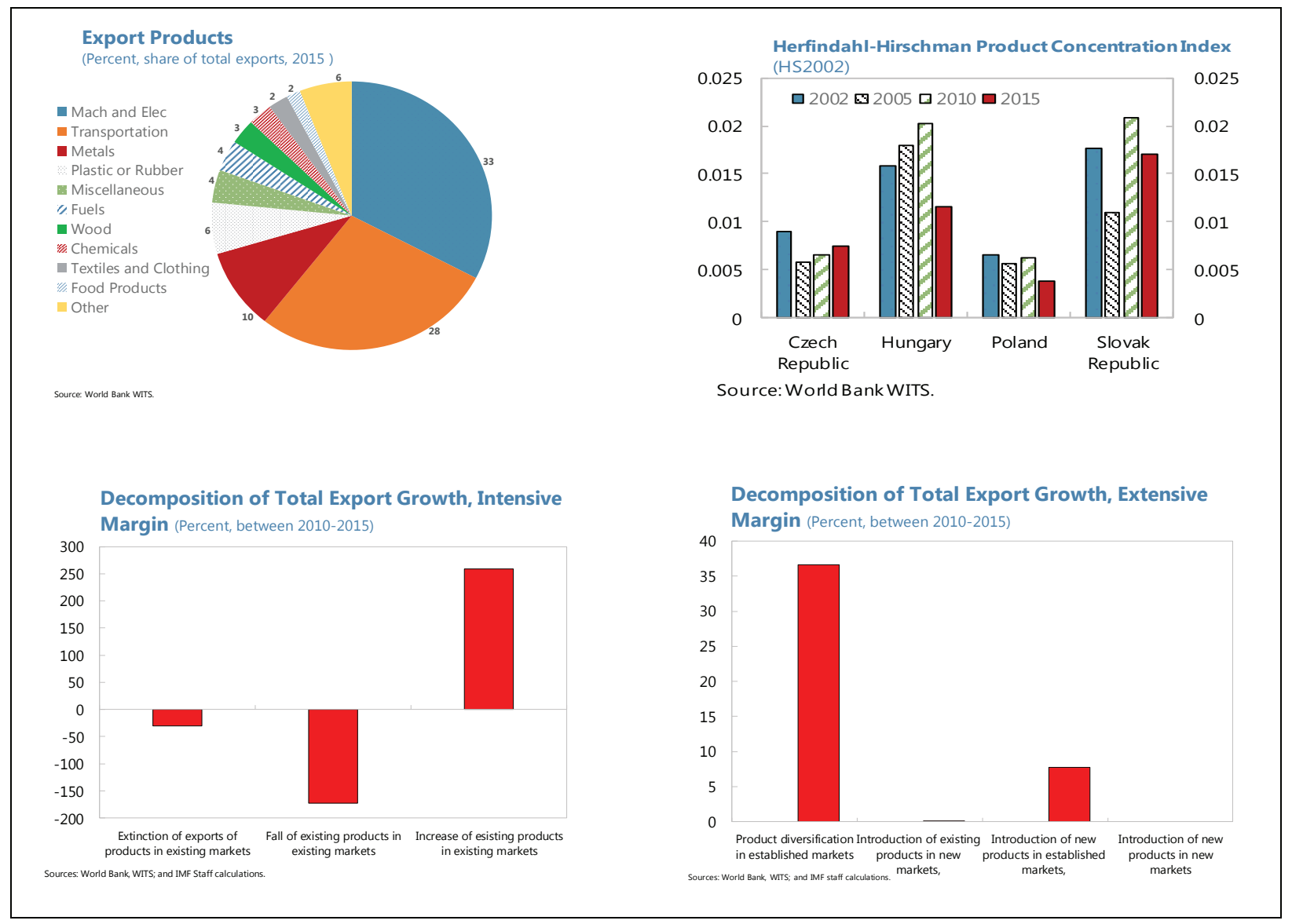

Mostly long-term and local-currency-denominated external liabilities provide a cushion against possible vulnerabilities. High EU-funds absorption in 2015 boosted the capital account balance. Net FDI inflows have recently picked up and are projected to peak in 2019, reflecting large investments by a fourth car maker. The portfolio investment balance turned positive in 2015 reflecting declining liabilities in the form of debt securities held by the government. External debt is forecast to reach 85 percent of GDP in 2016, while the net international position is expected to reach -68 percent. External debt, mostly issued by the general government, has long term maturities and is denominated in euros. The stock of liabilities is concentrated in FDI. These considerations mitigate concerns about external vulnerabilities.

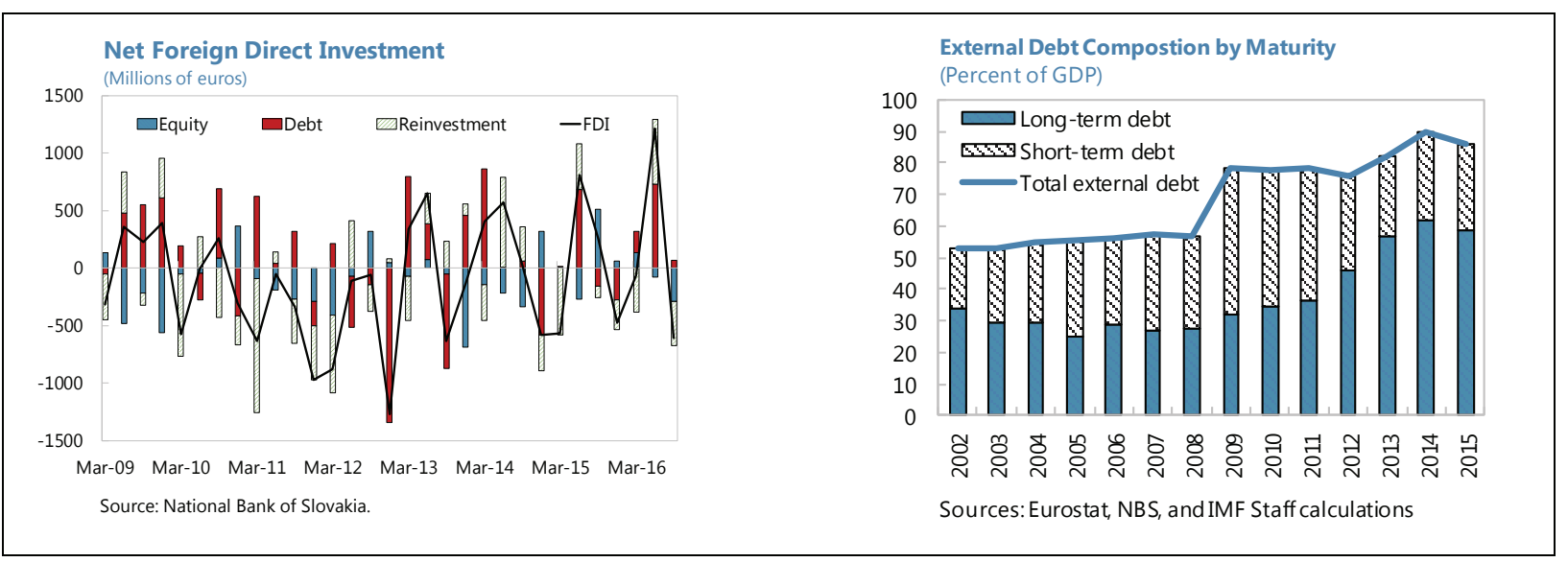




\section{Annex III. Public Debt Sustainability Analysis (DSA)}

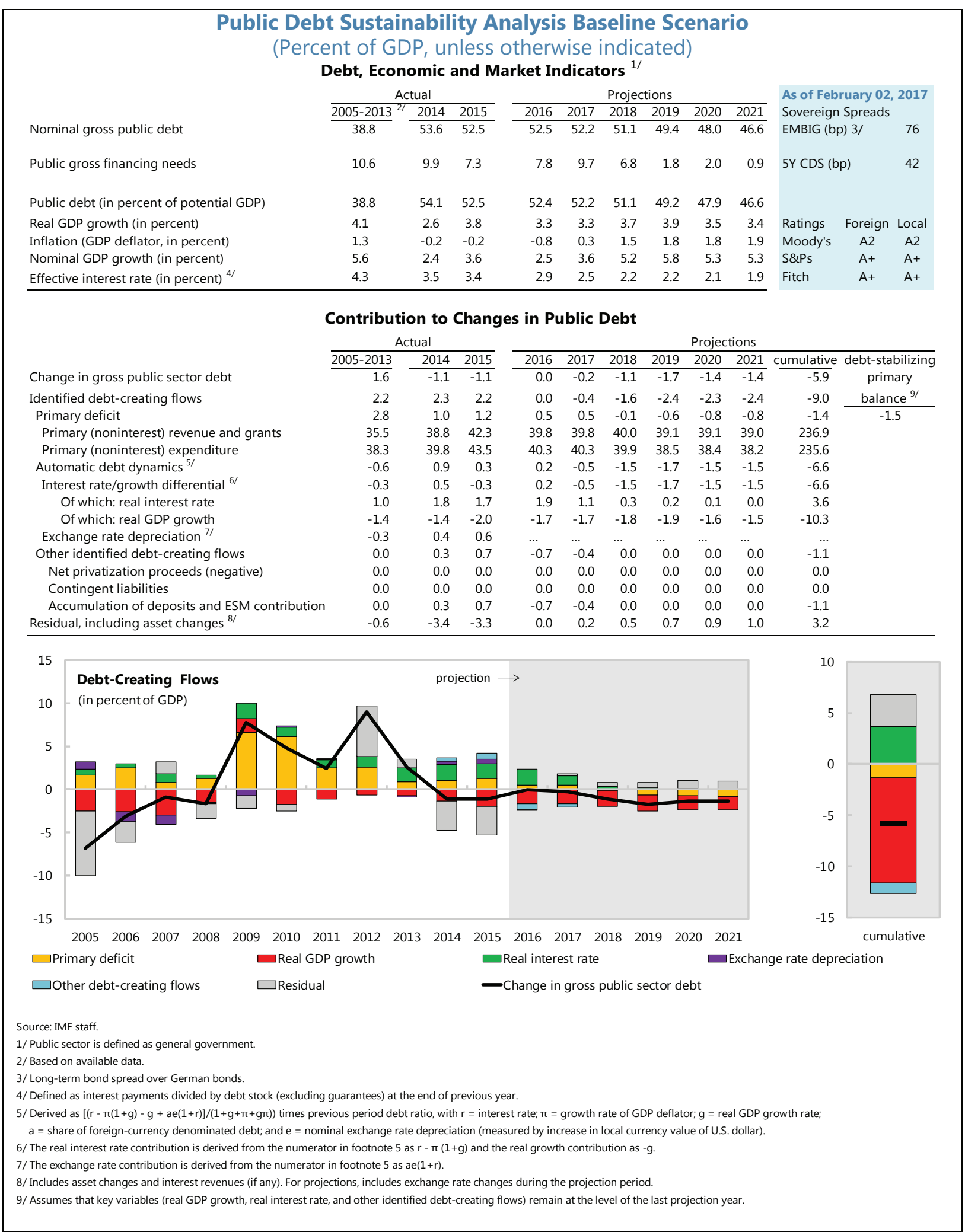




\section{Public DSA - Composition of Public Debt and Alternative Scenarios}

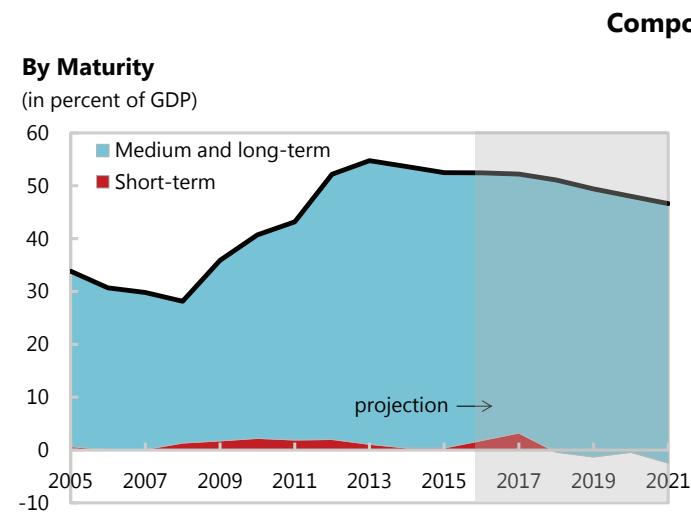

\section{Composition of Public Debt}

By Currency

(in percent of GDP)

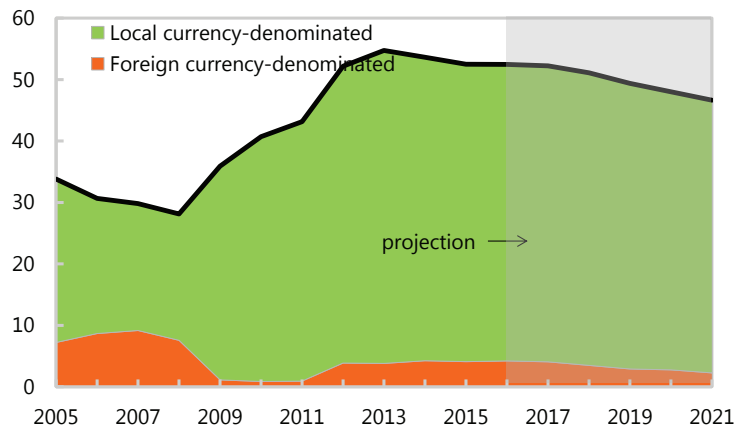

\section{Alternative Scenarios}

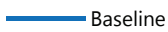

" Historical

- - Constant Primary Balance

\section{Gross Nominal Public Debt}

(in percent of GDP)

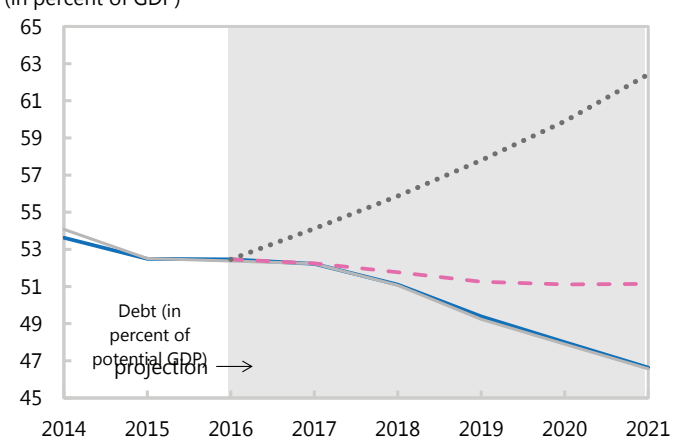

Public Gross Financing Needs

(in percent of GDP)

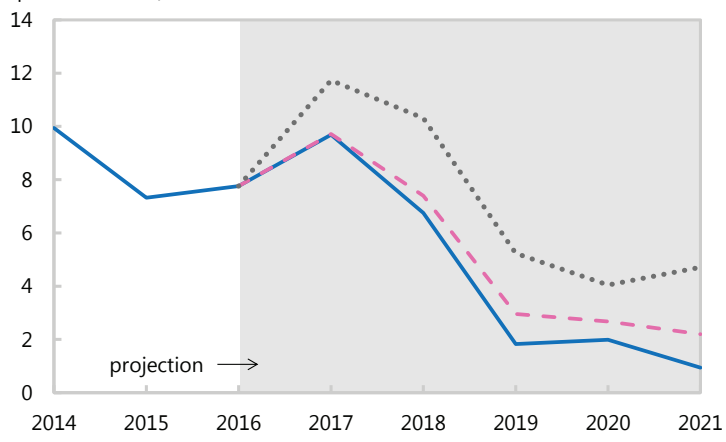

Underlying Assumptions

(in percent)

\begin{tabular}{lrrrrrr}
\cline { 2 - 7 } Baseline Scenario & 2016 & 2017 & 2018 & 2019 & 2020 & 2021 \\
\cline { 2 - 7 }$\quad$ Real GDP growth & 3.3 & 3.3 & 3.7 & 3.9 & 3.5 & 3.4 \\
$\quad$ Inflation & -0.8 & 0.3 & 1.5 & 1.8 & 1.8 & 1.9 \\
$\quad$ Primary Balance & -0.5 & -0.5 & 0.1 & 0.6 & 0.8 & 0.8 \\
$\quad$ Effective interest rate & 2.9 & 2.5 & 2.2 & 2.2 & 2.1 & 1.9 \\
Constant Primary Balance Scenario & & & & & & \\
$\quad$ Real GDP growth & 3.3 & 3.3 & 3.7 & 3.9 & 3.5 & 3.4 \\
Inflation & -0.8 & 0.3 & 1.5 & 1.8 & 1.8 & 1.9 \\
$\quad$ Primary Balance & -0.5 & -0.5 & -0.5 & -0.5 & -0.5 & -0.5 \\
Effective interest rate & 2.9 & 2.5 & 2.2 & 2.2 & 2.1 & 1.9 \\
\hline
\end{tabular}

Source: IMF staff.

Historical Scenario

Real GDP growth

Inflation

Primary Balance

Effective interest rate

\begin{tabular}{rrrrrr}
\hline 2016 & 2017 & 2018 & 2019 & 2020 & 2021 \\
\hline 3.3 & 3.7 & 3.7 & 3.7 & 3.7 & 3.7 \\
-0.8 & 0.3 & 1.5 & 1.8 & 1.8 & 1.9 \\
-0.5 & -2.6 & -2.6 & -2.6 & -2.6 & -2.6 \\
2.9 & 2.5 & 2.6 & 2.7 & 2.8 & 2.8
\end{tabular}


Public DSA - Realism of Baseline Assumptions

\section{Forecast Track Record, versus surveillance countries}

\section{Real GDP Growth}

(in percent, actual-projection)

Slovak Republic median forecast error, 2005-2013: $\quad-1.27$

Has a percentile rank of

$16 \%$

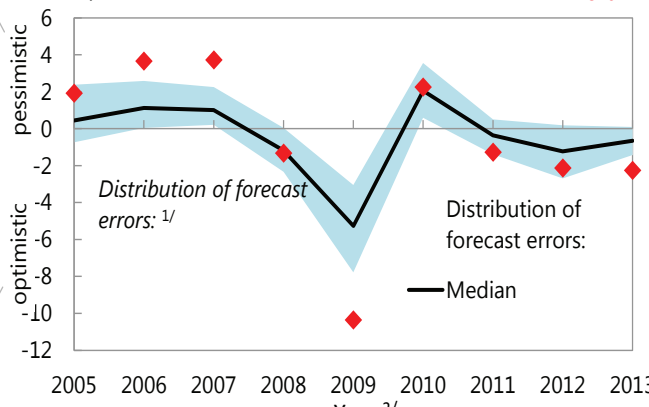

Year 21

\section{Primary Balance}

(n percent of GDP, actual-projection

Has a percentile rank of

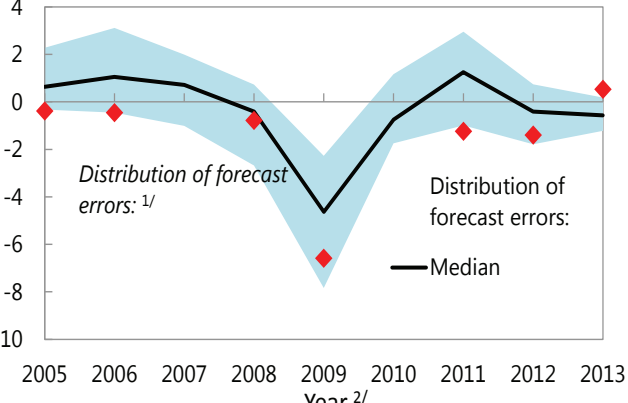

Slovak Republic median forecast error, 2005-2013: $\quad-0.78$

\section{Inflation (Deflator)}

(in percent, actual-projection)

Slovak Republic median forecast error, 2005-2013: $\quad-0.69$ Has a percentile rank of

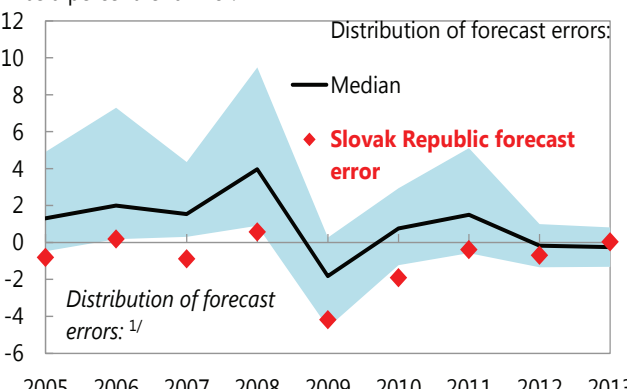

$\begin{array}{lllllllll}2005 & 2006 & 2007 & 2008 & 2009 & 2010 & 2011 & 2012 & 2013\end{array}$

Year $^{2 /}$

\section{Boom-Bust Analysis ${ }^{3 /}$}

3-Year Adjustment in Cyclically-Adjusted Primary Balance (CAPB)

$$
\text { (Percent of GDP) }
$$

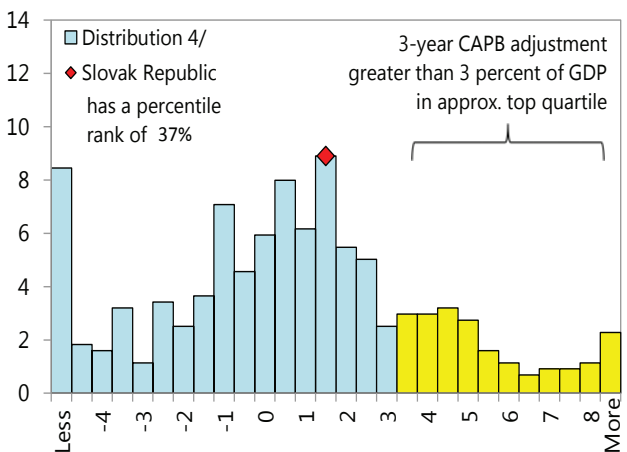

3-Year Average Level of Cyclically-Adjusted Primary

\section{Balare (CAPB)}

(Percent of GDP)

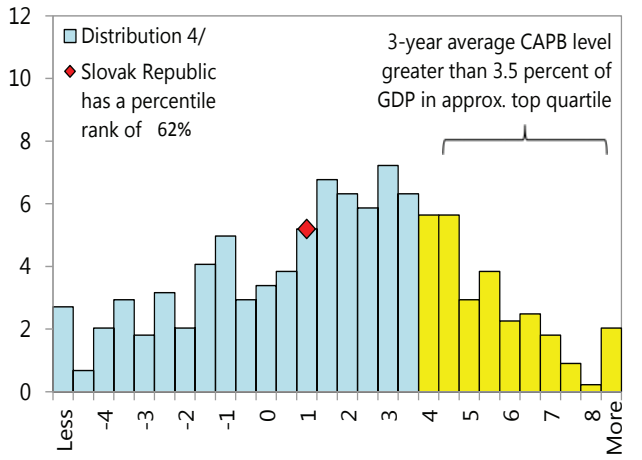

\section{Real GDP growth}

(in percent)

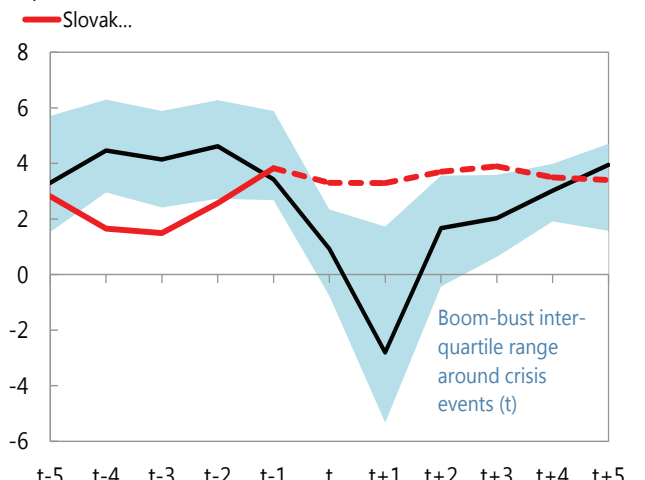

Source : IMF Staff.

$1 /$ Plotted distribution includes surveillance countries, percentile rank refers to all countries.

2/ Projections made in the spring WEO vintage of the preceding year.

3/ Slovak Republic has had a positive output gap for 3 consecutive years, 2013-2015. For Slovak Republic, $t$ corresponds to 2016; for the distribution, $t$ corresponds to the first year of the crisis.

4/ Data cover annual obervations from 1990 to 2011 for advanced and emerging economies with debt greater than 60 percent of GDP. Percent of sample on vertical axis. 


\section{Public DSA - Stress Tests}

\section{Macro-Fiscal Stress Tests}

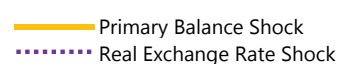

Gross Nominal Public Debt

Gross Nominal Public Debt

(in percent of GDP)

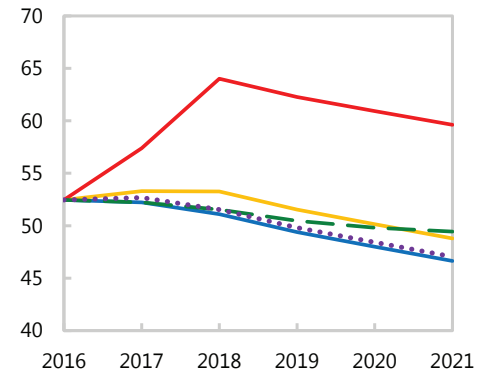

Baseline

Gross Nominal Public Debt

(in percent of GDP)

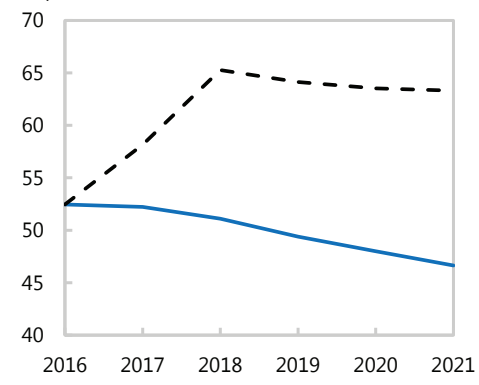

(in percent of Revenue)

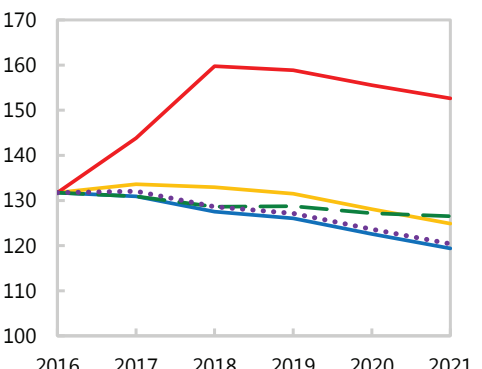

Additional Stress Tests

- - Combined Macro-Fiscal Shock

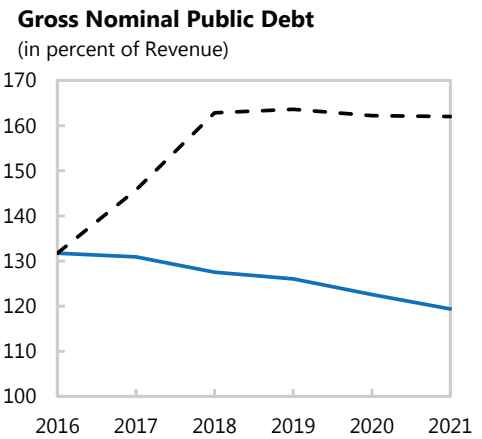

Underlying Assumptions

(in percent) Real GDP growth

Inflation

Primary balance

Effective interest rate

Real Interest Rate Shock

Real GDP growth

Inflation

Primary balance

Effective interest rate

Combined Shock

Real GDP growth

Inflation

Primary balance

Effective interest rate

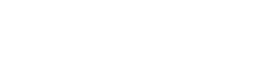

Real GDP Growth Shock Real GDP growth

Inflation

Primary balance

Effective interest rate

Real Exchange Rate Shock Real GDP growth

Inflation

Primary balance

Effective interest rate
_ - Real Interest Rate Shock

Public Gross Financing Needs (in percent of GDP)

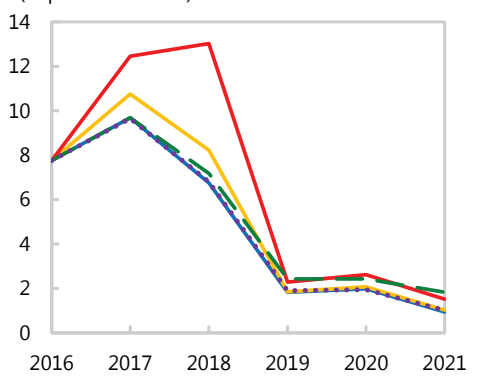

Public Gross Financing Needs

(in percent of GDP)

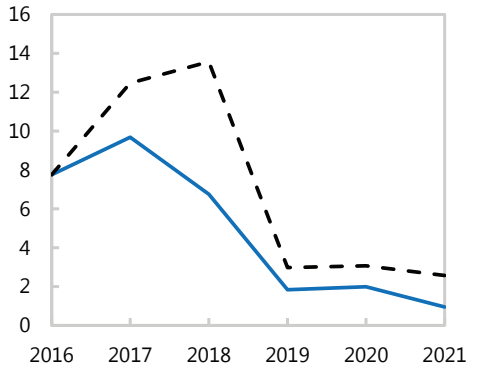

Source: IMF staff. 


\section{Public DSA - Risk Assessment \\ Heat Map}

\begin{tabular}{|c|c|c|c|c|c|}
\hline Debt level ${ }^{1 /}$ & $\begin{array}{c}\text { Real GDP } \\
\text { Growth Shock }\end{array}$ & $\begin{array}{c}\text { Primary } \\
\text { Balance Shock }\end{array}$ & $\begin{array}{l}\text { Real Interest } \\
\text { Rate Shock }\end{array}$ & $\begin{array}{c}\text { Exchange Rate } \\
\text { Shock }\end{array}$ & $\begin{array}{c}\text { Contingent } \\
\text { Liability shock }\end{array}$ \\
\hline Gross financing needs ${ }^{2 /}$ & $\begin{array}{c}\text { Real GDP } \\
\text { Growth Shock }\end{array}$ & $\begin{array}{c}\text { Primary } \\
\text { Balance Shock }\end{array}$ & $\begin{array}{l}\text { Real Interest } \\
\text { Rate Shock }\end{array}$ & $\begin{array}{c}\text { Exchange Rate } \\
\text { Shock }\end{array}$ & $\begin{array}{c}\text { Contingent } \\
\text { Liability Shock }\end{array}$ \\
\hline Debt profile ${ }^{3 /}$ & $\begin{array}{c}\text { Market } \\
\text { Perception }\end{array}$ & $\begin{array}{c}\text { External } \\
\text { Financing } \\
\text { Requirements }\end{array}$ & $\begin{array}{l}\text { Change in the } \\
\text { Share of Short- } \\
\text { Term Debt }\end{array}$ & $\begin{array}{l}\text { Public Debt } \\
\text { Held by Non- } \\
\text { Residents }\end{array}$ & $\begin{array}{l}\text { Foreign } \\
\text { Currency } \\
\text { Debt }\end{array}$ \\
\hline
\end{tabular}

\section{Evolution of Predictive Densities of Gross Nominal Public Debt}

(in percent of GDP)

Baseline Percentiles: $\quad$ 10th-25th $\quad$ 25th-75th $\quad$ 75th-90th

\section{Symmetric Distribution}

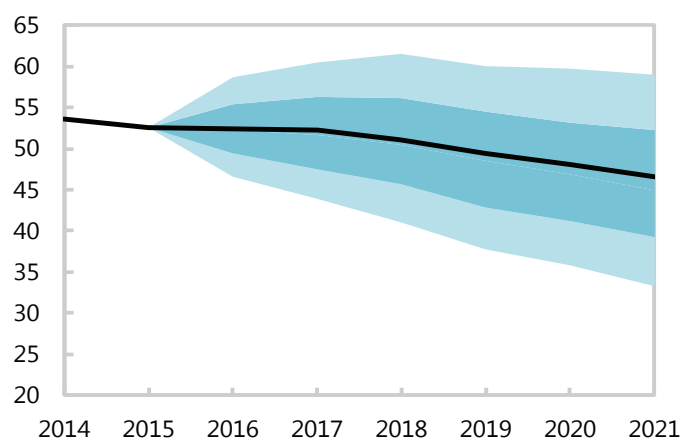

\section{Restricted (Asymmetric) Distribution}

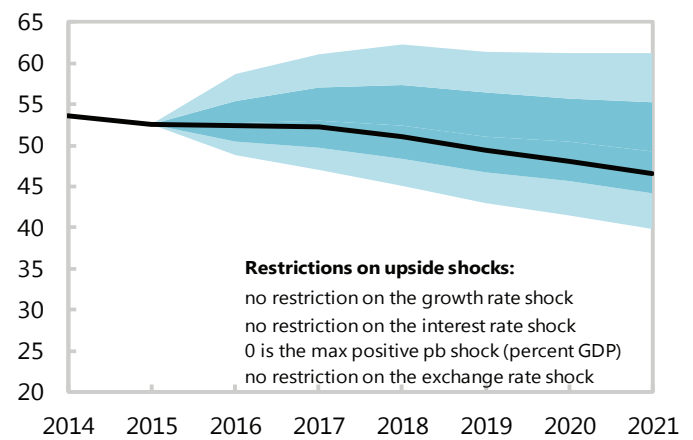

Debt Profile Vulnerabilities

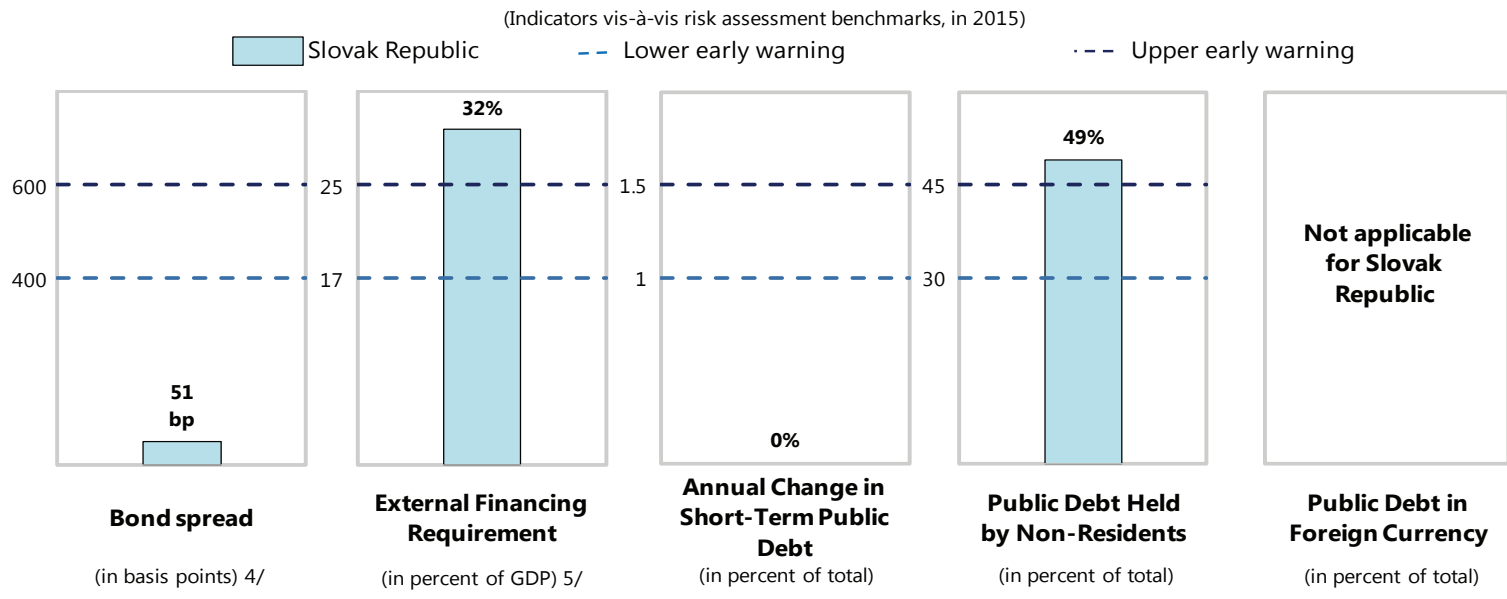

Source: IMF staff.

1 / The cell is highlighted in green if debt burden benchmark of $85 \%$ is not exceeded under the specific shock or baseline, yellow if exceeded under specific shock but not baseline, red if benchmark is exceeded under baseline, white if stress test is not relevant.

$2 /$ The cell is highlighted in green if gross financing needs benchmark of $20 \%$ is not exceeded under the specific shock or baseline, yellow if exceeded under specific shock but not baseline, red if benchmark is exceeded under baseline, white if stress test is not relevant.

3/ The cell is highlighted in green if country value is less than the lower risk-assessment benchmark, red if country value exceeds the upper risk-assessment benchmark, yellow if country value is between the lower and upper risk-assessment benchmarks. If data are unavailable or indicator is not relevant, cell is white.

Lower and upper risk-assessment benchmarks are:

400 and 600 basis points for bond spreads; 17 and 25 percent of GDP for external financing requirement; 1 and 1.5 percent for change in the share of short-term debt; 30 and 45 percent for the public debt held by non-residents.

4/ Long-term bond spread over German bonds, an average over the last 3 months, 04-Nov-16 through 02-Feb-17.

5/ External financing requirement is defined as the sum of current account deficit, amortization of medium and long-term total external debt, and short-term total external debt at the end of previous period. 


\section{Annex IV. External Debt Sustainability Analysis (DSA)}

\section{External Debt Sustainability: Bound Tests 1/ 2/ \\ (External debt in percent of GDP)}

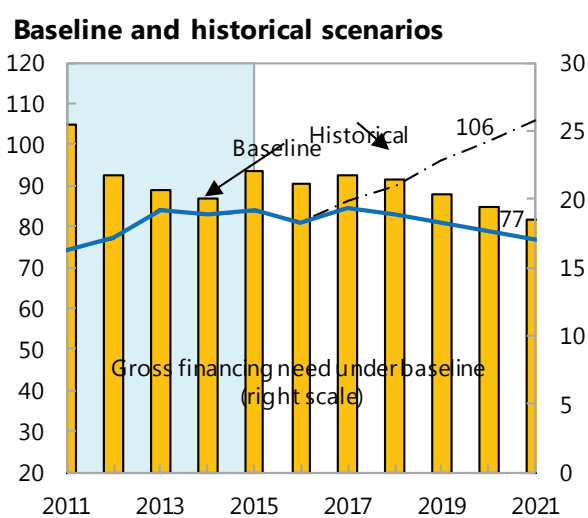

Interest rate shock (in percent)

rowth shock
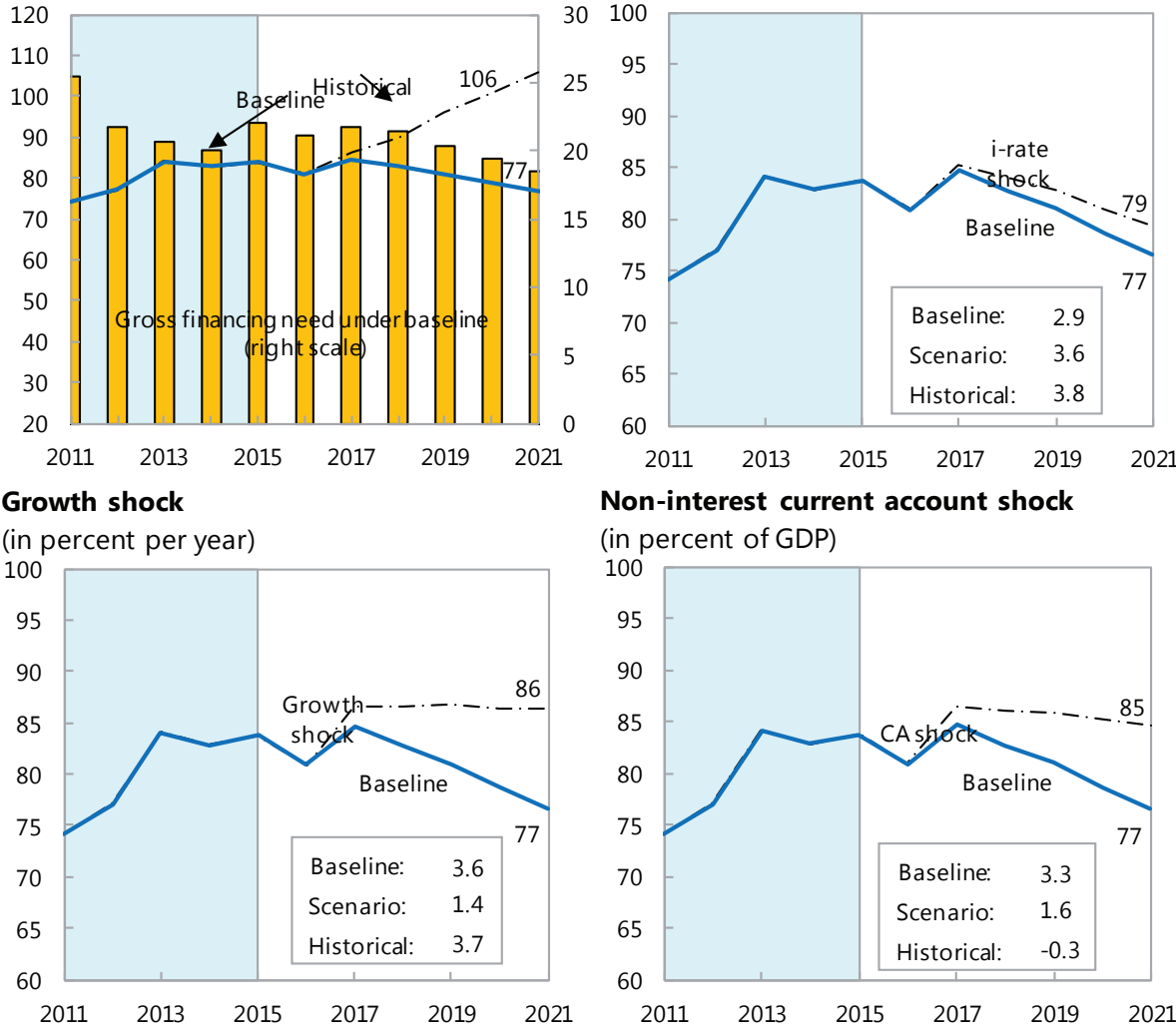

Non-interest current account shock

(in percent of GDP)

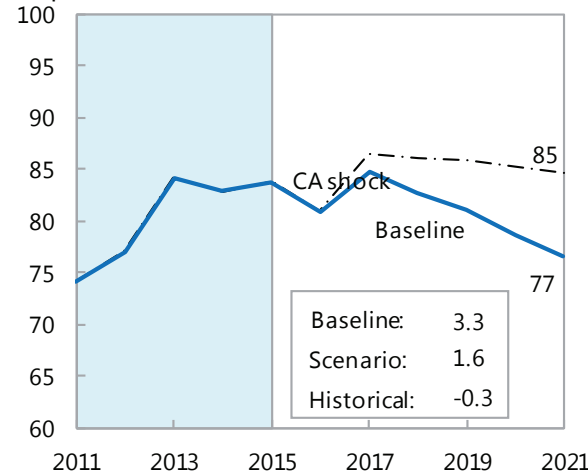

\section{Combined shock 3/}
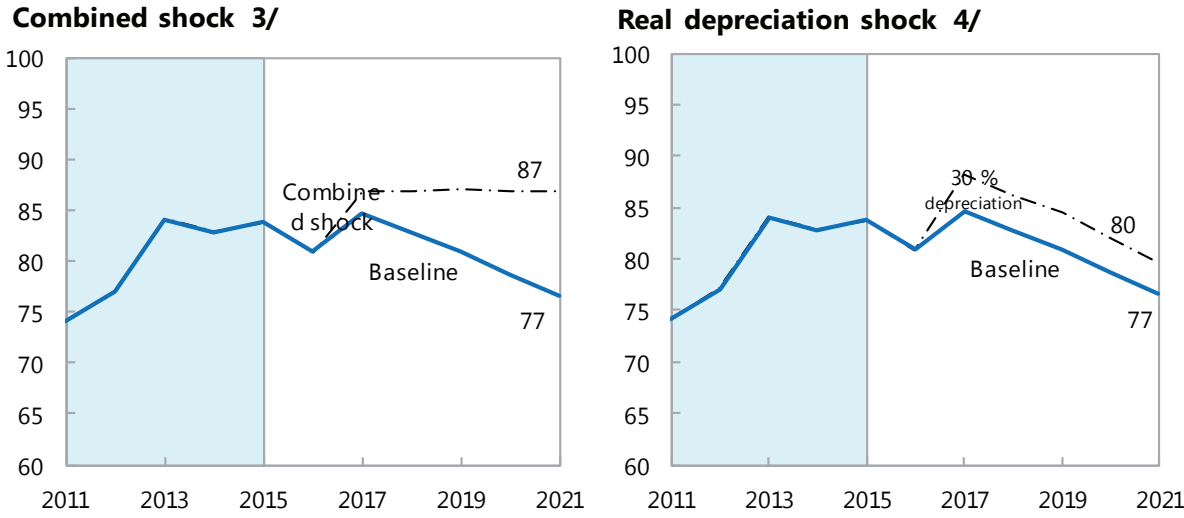

Sources: International Monetary Fund, Country desk data, and staff estimates.

1/ Shaded areas represent actual data. Individual shocks are permanent one-half standard deviation shocks. Figures in the boxes represent average projections for the respective variables in the baseline and scenario being presented. Ten-year historical average for the variable is also shown.

2/ For historical scenarios, the historical averages are calculated over the ten-year period, and the information is used to project debt dynamics five years ahead.

3/ Permanent 1/4 standard deviation shocks applied to real interest rate, growth rate, and current account balance.

4/ One-time real depreciation of 30 percent occurs in 2017. 


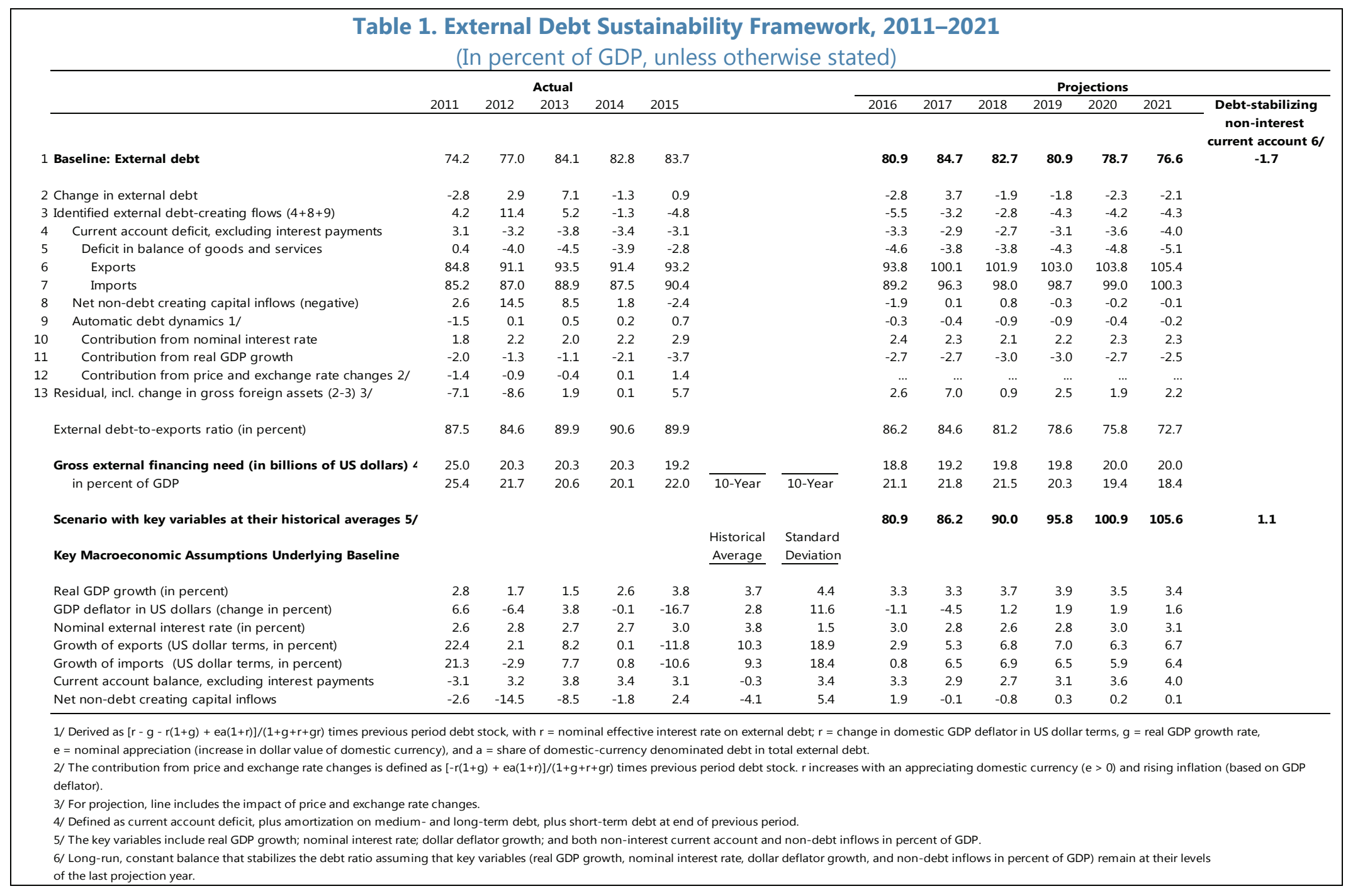




\section{INTERNATIONAL MONETARY FUND}

\section{SLOVAK REPUBLIC}

STAFF REPORT FOR THE 2017 ARTICLE IV

CONSULTATION-INFORMATIONAL ANNEX

Prepared By European Department

\section{CONTENTS}

FUND RELATIONS

$\underline{\mathbf{2}}$

STATISTICAL ISSUES

$\underline{5}$ 


\section{FUND RELATIONS}

As of January 31, 2017

Membership Status: Joined January 01,1993; Article VIII

$\begin{array}{lrr}\text { General Resources Account: } & \text { SDR Million } & \text { Percent of Quota } \\ \text { Quota } & 1,001.00 & 100.00 \\ \text { Fund holdings of currency } & 847.61 & 84.68 \\ \text { Reserve position } & 153.39 & 15.32 \\ \text { Lending to the Fund } & & \\ & & \\ \text { SDR Department: } & \text { SDR Million } & \text { Percent of Allocation } \\ \text { Net cumulative allocation } & 340.48 & 100.00 \\ \text { Holdings } & 185.33 & 54.4\end{array}$

Outstanding Purchases and Loans: None

Financial Arrangements:

$\begin{array}{ccccc}\text { Type } & \begin{array}{c}\text { Date of } \\ \text { Arrangement }\end{array} & \begin{array}{c}\text { Expiration } \\ \text { Date }\end{array} & \begin{array}{c}\text { Amount Approved } \\ \text { (SDR Million) }\end{array} & \begin{array}{c}\text { Amount Drawn } \\ \text { (SDR Million) }\end{array} \\ \text { Stand-by } & 7 / 22 / 1994 & 3 / 21 / 1996 & 115.80 & 32.15\end{array}$

Projected Payments to Fund:

(SDR Million; based on existing use of resources and present holdings of SDRs):

\begin{tabular}{ccccc}
\multicolumn{5}{c}{ Forthcoming } \\
\hline $\mathbf{2 0 1 7}$ & $\mathbf{2 0 1 8}$ & $\mathbf{2 0 1 9}$ & $\mathbf{2 0 2 0}$ & $\mathbf{2 0 2 1}$ \\
& & & & \\
0.48 & 0.51 & 0.51 & 0.51 & 0.51 \\
0.48 & 0.51 & 0.51 & 0.51 & 0.51
\end{tabular}

\section{Exchange Rate Arrangement:}

The currency of the Slovak Republic is the euro, which was adopted on January 1, 2009. The Slovak Republic has accepted the obligations of Article VIII, Sections 2, 3, and 4 and maintains an exchange system that is free of restrictions on the making of payments and transfers for current international transactions, other than those imposed for security reasons, based on UN Security Council Resolutions and Council of the European Union Regulations, and which have been notified to the Fund under the procedures set forth in Executive Board Decision No. 144-(42/51). 


\section{Article IV Consultation:}

The Slovak Republic is on a standard 12-month consultation cycle. The previous consultation with the Slovak Republic was concluded on January 14, 2016 (IMF Country Report No. 16/13).

\section{FSAP Participation and ROSCs:}

An FSAP was concluded with the completion of the 2002 Article IV consultation on August 7, 2002 (IMF Country Report No. 02/198). An FSAP update mission was held in December 2006 (IMF Country Report 07/243).

The report on the Fiscal ROSC was issued in August 2002 (IMF Country Report No. 02/189), and updates were issued in August 2003 (IMF Country Report No. 03/236) and in March 2005 (IMF Country Report No. 05/73). The report on the Data ROSC was issued in May 2005 (IMF Country Report No. 05/161).

Technical Assistance: See the attached table.

Resident Representative Post: None (closed at end-April 2004). 


\begin{tabular}{|c|c|c|}
\hline \multicolumn{3}{|c|}{ Slovak Republic: Technical Assistance, 2000-2016 } \\
\hline Department & Timing & Purpose \\
\hline \multirow[t]{3}{*}{ MFD } & February 2000 & $\begin{array}{l}\text { Mission on pros and cons, and modalities of } \\
\text { moving to an inflation targeting framework, } \\
\text { operational issues (money markets and policy } \\
\text { instruments), and dealing with potential } \\
\text { problems posed by capital inflows for monetary } \\
\text { operations }\end{array}$ \\
\hline & December 2001 & $\begin{array}{l}\text { Long-term resident expert on banking } \\
\text { supervision }\end{array}$ \\
\hline & May 2002 & Two missions on inflation modeling \\
\hline \multirow[t]{16}{*}{ FAD } & April 2000 & Tax administration \\
\hline & February 2001 & Tax administration (follow-up) \\
\hline & April 2001 & Public Finance Management (follow-up) \\
\hline & August 2001 & $\begin{array}{l}\text { Tax administration: Installation of resident expert } \\
\text { to advise on establishment of Large Taxpayer } \\
\text { Unit (LTU) }\end{array}$ \\
\hline & $\begin{array}{l}\text { August 2001- } \\
\text { August } 2002\end{array}$ & $\begin{array}{l}\text { Regular visits by FAD consultant on } \\
\text { establishment of LTU }\end{array}$ \\
\hline & December 2001 & $\begin{array}{l}\text { Tax administration follow-up, tax } \\
\text { investigation/fraud issues }\end{array}$ \\
\hline & June 2002 & $\begin{array}{l}\text { Mission to prepare Report on the Observance of } \\
\text { Standards and Codes (ROSC), Fiscal } \\
\text { Transparency Module }\end{array}$ \\
\hline & February 2003 & Tax policy \\
\hline & March 2003 & Tax administration \\
\hline & May 2003 & Expenditure policy \\
\hline & December 2013 & VAT Gap Analysis \\
\hline & November 2015 & Expenditure review workshop \\
\hline & December 2015 & VAT gap follow-up and excise gap analysis \\
\hline & April 2016 & Expenditure review \\
\hline & December 2016 & Expenditure review \\
\hline & November 2016 & Tax efficiency \\
\hline \multirow[t]{4}{*}{ STA } & February 2000 & National accounts and price statistics \\
\hline & March 2001 & Multi sector mission \\
\hline & July 2003 & Government finance statistics \\
\hline & February-March 2004 & Data ROSC mission \\
\hline
\end{tabular}




\section{STATISTICAL ISSUES}

1. Coverage, periodicity, and timeliness of data provided to the Fund are adequate for surveillance purposes. The Slovak Republic has subscribed to the Special Data Dissemination Standard (SDDS) since 1996 and observes or exceeds all related standards. The Slovak Republic is subject to the statistical requirements and timeliness and reporting standards or Eurostat and the European Central Bank (ECB).

2. Real sector. All data on national accounts follow the ESA 2010.

3. Fiscal sector. The compilation of general government statistics is in line with the ESA 2010. Monthly reconciliation of government operations above and below the line is restricted to state budget transactions on a cash basis, and the reconciliation of general government operations above and below the line are available only with a long lag.

4. External sector. External sector statistics are generally of good quality, and are reported on a timely basis to the Fund. However, errors and omissions in the balance of payments statistics are large and reported financial account flows are subject to large volatility. The statistical authorities are aware of these issues and are working to address them. The statistical authorities started to submit data to the Fund following the standard of the sixth edition of the Balance of Payments and International Investment Position Manual (BPM6) in September 2014 and have provided data back to 2004 .

5. Monetary and financial sector. Monetary and financial statistics are of good quality and are reported on a timely basis to the Fund, or made publicly available. 
Table 1. Slovak Republic: Table of Common Indicators Required for Surveillance

\begin{tabular}{|c|c|c|c|c|c|}
\hline & $\begin{array}{l}\text { Date of Latest } \\
\text { Observation }\end{array}$ & $\begin{array}{c}\text { Date } \\
\text { Received }\end{array}$ & $\begin{array}{l}\text { Frequency of } \\
\text { Data }^{6 /}\end{array}$ & $\begin{array}{l}\text { Frequency of } \\
\text { Reporting }{ }^{6 /}\end{array}$ & $\begin{array}{l}\text { Frequency of } \\
\text { Publication }{ }^{6 /}\end{array}$ \\
\hline Exchange Rates & Current & Current & $\mathrm{D}$ & $\mathrm{D}$ & $\mathrm{D}$ \\
\hline $\begin{array}{l}\text { International Reserve Assets and Reserve } \\
\text { Liabilities of the Monetary Authorities }^{1}\end{array}$ & January 2017 & $\begin{array}{l}\text { February } \\
2016\end{array}$ & $\mathrm{D}$ & W & W \\
\hline Reserve/Base Money & $\begin{array}{l}\text { December } \\
2016\end{array}$ & $\begin{array}{l}\text { January } \\
2017\end{array}$ & M & M & M \\
\hline Broad Money & $\begin{array}{l}\text { December } \\
2016\end{array}$ & $\begin{array}{l}\text { January } \\
2017\end{array}$ & M & M & M \\
\hline Central Bank Balance Sheet & $\begin{array}{l}\text { December } \\
2016\end{array}$ & $\begin{array}{l}\text { January } \\
2017\end{array}$ & M & M & M \\
\hline $\begin{array}{l}\text { Consolidated Balance Sheet of the } \\
\text { Banking System }\end{array}$ & $\begin{array}{l}\text { December } \\
2016\end{array}$ & $\begin{array}{l}\text { January } \\
2017\end{array}$ & M & M & M \\
\hline Interest Rates $^{2}$ & Current & Current & $\mathrm{D}$ & $\mathrm{D}$ & $\mathrm{D}$ \\
\hline Consumer Price Index & $\begin{array}{l}\text { December } \\
2016\end{array}$ & $\begin{array}{l}\text { January } \\
2017\end{array}$ & M & M & M \\
\hline $\begin{array}{l}\text { Revenue, Expenditure, Balance and } \\
\text { Composition of Financing }{ }^{3}-\text { General } \\
\text { Government }{ }^{4}\end{array}$ & 2015 & July 2016 & A & A & $A$ \\
\hline $\begin{array}{l}\text { Revenue, Expenditure, Balance and } \\
\text { Composition of Financing }{ }^{3}-\text { Central } \\
\text { Government }\end{array}$ & January 2017 & $\begin{array}{l}\text { February } \\
2017\end{array}$ & M & M & M \\
\hline $\begin{array}{l}\text { Stocks of Central Government and Central } \\
\text { Government-Guaranteed Debt }{ }^{5}\end{array}$ & 2016Q3 & $\begin{array}{l}\text { December } \\
2016\end{array}$ & Q & Q & Q \\
\hline External Current Account Balance & $\begin{array}{l}\text { November } \\
2016\end{array}$ & $\begin{array}{l}\text { February } \\
2017\end{array}$ & M & M & M \\
\hline Exports and Imports of Goods and Services & $\begin{array}{l}\text { December } \\
2016\end{array}$ & $\begin{array}{l}\text { February } \\
2017\end{array}$ & M & M & M \\
\hline GDP/GNP & 2016Q3 & $\begin{array}{l}\text { December } \\
2016\end{array}$ & Q & Q & Q \\
\hline Gross External Debt & 2016Q3 & $\begin{array}{l}\text { December } \\
2016\end{array}$ & Q & Q & Q \\
\hline International Investment Position ${ }^{7}$ & 2016Q3 & $\begin{array}{l}\text { December } \\
2016\end{array}$ & Q & Q & Q \\
\hline $\begin{array}{l}{ }^{1} \text { Includes reserve assets pledged or otherwise encu } \\
{ }^{2} \text { Both market-based and officially-determined, incl } \\
{ }^{2} \text { Foreign, domestic bank, and domestic nonbank fi } \\
{ }^{4} \text { The general government consists of the central gc } \\
\text { governments. } \\
{ }^{5} \text { Including currency and maturity composition. } \\
{ }^{6} \text { Daily (D), Weekly (W), Monthly (M), Quarterly (Q), } \\
\text { Includes external gross financial asset and liability }\end{array}$ & $\begin{array}{l}\text { count rates, mone } \\
\text { (budgetary fund } \\
\text { (A), Irregular (I), N } \\
\text { vis-à-vis nonresi }\end{array}$ & $\begin{array}{l}\text { ive positions. } \\
\text { narket rates, ra } \\
\text { extra budgetary } \\
\text { Available (NA) } \\
\text { ts. }\end{array}$ & $\begin{array}{l}\text { s on treasury bills } \\
\text { unds, and social s }\end{array}$ & $\begin{array}{l}\text { hotes and bonds. } \\
\text { curity funds) and }\end{array}$ & ate and local \\
\hline
\end{tabular}

